Performing Conformity, Unleashing Craft:

Female Vocalists of Postwar Pop, 1945-1956

Sarah Elizabeth Culpeper

Charlottesville, Virginia

B.A., University of Toronto, 1998

B.F.A., Concordia University, 2002

M.A., McGill University, 2005

A Dissertation presented to the Graduate Faculty of the University of Virginia in Candidacy for the Degree of Doctor of Philosophy

Department of Music

University of Virginia

December, 2013 


\section{Abstract \\ Performing Conformity, Unleashing Craft: \\ Female Vocalists of Postwar Pop, 1945-1956}

By

\section{Sarah Elizabeth Culpeper}

This dissertation centers on female postwar pop singers and the hit records they made between the years 1945 and 1956. I consider the vocal styles of Doris Day, Patti Page and Mary Ford in combination with the personae and images they projected through records and other media. The project serves in part to document and recuperate the sometimes-disparaged genre of postwar pop, and to restore its neglected female singers to popular music history narratives.

I glean my understanding of the singing voice from pedagogy and science literature, and from these sources I build a technique-based analytical vocabulary for vocal style. I apply this vocabulary to close readings and interpretations of the singers' hit recordings, and I bring my readings into dialogue with historical reception discourse. To understand how the singers may have resonated with postwar audiences beyond the vocal dimension, I connect the images they projected to historical scholarship about gender and sexuality in postwar America.

All three singers presented a degree of conformity while also complicating the era's mores. Day never transgressed norms of postwar sexual propriety, yet the discourse around her appeal suggests that audiences found her sexually desirable. Page presented a placid poise in her media appearances, something that contrasted strikingly with her reputation as a dazzlingly powerful singer. Ford and her husband 
Les Paul often presented themselves as an ideal postwar couple, and yet a narrative of marital fracture seeps into some of these presentations.

I argue that the vocal craft of Day, Page and Ford centered on relaxed pop singing: a style that has since fallen out of favor in the popular sphere, and for this reason can be difficult to appreciate today. But when Day, Page and Ford made records, they presented unique articulations of the desirable pop singing aesthetic of the era: one that was characterized by a smooth vocal tone, and the conveyance of ease and warmth. 


\section{TABLE OF CONTENTS}

List of Tables

List of Figures

Acknowledgments

Introduction

1. Framing the Study of Postwar Pop Singers

2. Doris Day: Workaround Technique, Safe Sexuality

3. Patti Page: Placidity, Poise and Power

4. Mary Ford: Unsung Talent, Interactive Muse

Appendix 


\section{List of Tables}

TABLE 1.1 STYLE CATEGORIES FOR POSTWAR POP RECORDINGS 1945-1956

TABLE 1.2 PROPORTION OF SINGERS TO BANDLEADERS/INSTRUMENTALISTS COMPRISING THE TOP 10 ARTISTS OF THE DECADE 1930-1950.

TABLE 1.3 PROPORTION OF SINGERS TO BANDLEADERS/INSTRUMENTALISTS COMPRISING THE TOP 20 ARTISTS FOR FIVE-YEAR INCREMENTS, 1940-1954

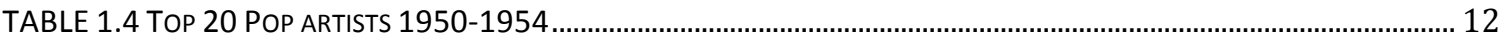

TABLE 1.5: COMMON DESCRIPTORS USED IN THE HISTORICAL RECEPTION OF DORIS DAY, PATTI PAGE AND MARY FORD ....... 13

TABLE 1.6 BATEMAN'S PROPOSED VOCAL REGISTER AND MECHANISM CATEGORIES FOR THE FEMALE VOICE 38

TABLE 1.7 ADAPTED TERMS FOR AND HYPOTHESIZED USAGE OF VOCAL REGISTER AND MECHANISM CATEGORIES FOR THE FEMALE VOICE

TABLE 2.1 HIT SONGS RECORDED BY LES BROWN FEATURING DORIS DAY................................................................. 50

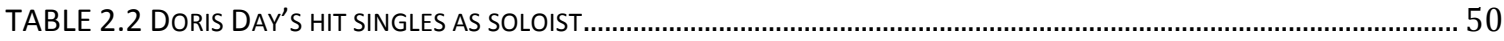

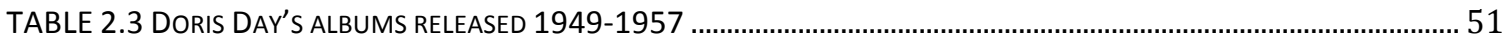

TABLE 2.4 DORIS DAY'S PRONUNCIATION IN “SENTIMENTAL JOURNEY” (SECOND A SECTION)...........................................68

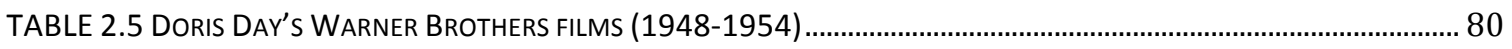

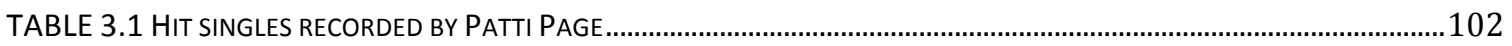

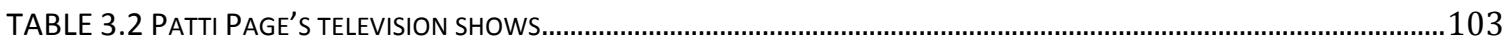

TABLE 3.3 STYLE OF PAGE'S 34 TOP-CHARTING SINGLES ....................................................................................... 126

TABLE 3.4 STYLE OF PAGE'S 34 TOP-CHARTING SINGLES: COUNT AND PROPORTION ........................................................126

TABLE 3.5 VOCAL TEXTURES ON PAGE'S 34 TOP-CHARTING SINGLES: DESCRIPTIONS, CODES...............................................133

TABLE 3.6 VOCAL TEXTURE ON PAGE'S 34 TOP-CHARTING SINGLES ..............................................................................133

TABLE 3.7 VOCAL TEXTURE ON PAGE'S 34 TOP-CHARTING SINGLES: COUNT AND PROPORTIONS..........................................134

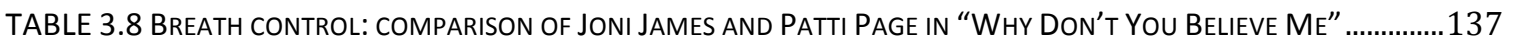

TABLE 3.9 ELEMENTS OF CLASSICAL VOCAL TECHNIQUE APPLICABLE TO PAGE'S SINGING .................................................141

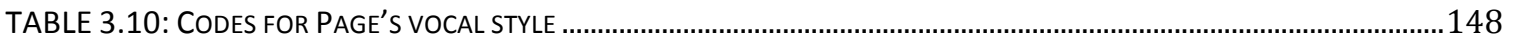

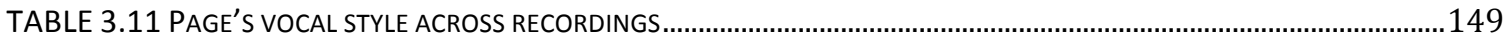

TABLE 3.12 DISTRIBUTION OF VOCAL MODE ACROSS PATTI PAGE'S TOP 34 HIT SINGLES ..................................................150

TABLE 4.1 LES PAUL AND MARY FORD: SINGLES CHARTING IN TOP 20, 1950-1955 ...................................................155

TABLE 4.2 LES PAUL AND MARY FORD: RADIO AND TELEVISION PROGRAMS .................................................................155

TABLE 4.3 SUMMARY OF VOCAL TEXTURES AND FORD'S VOICE QUALITY ACROSS TOP SINGLES ACCORDING TO SONG STYLE ..161

TABLE 4.4 AVERAGE SINGING RANGES ON 4 HIGHEST CHARTING SINGLES BY FORD, PAGE AND DAY..... 161

TABLE 4.5 COMPARISON OF FORD'S AVERAGE RANGE IN TOP 5 HIGHEST CHARTING SINGLES TO AVERAGE ACROSS 5 LOWEST RANGE SONGS AND 5 HIGHEST RANGE SONGS.

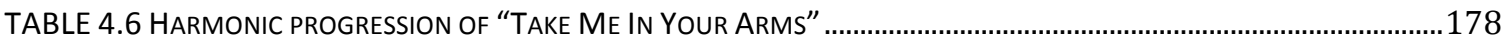

TABLE 4.7 BASIC FORM OF “HOW HIGH THE MOON” (32-BAR CHORUS ABAB') .............................................................188

TABLE 4.8 COMPARISON OF FORMAL STRUCTURES IN FIVE RECORDINGS OF “HOW HIGH THE MOON” ................................188

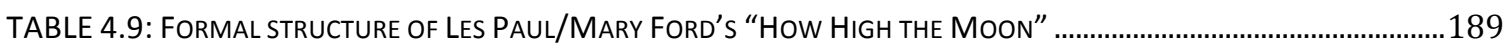

TABLE 4.10 TEXTURE DIFFERENCES BETWEEN SECTION 1 AND SECTION 3 OF “HOW HIGH THE MOON"................................189

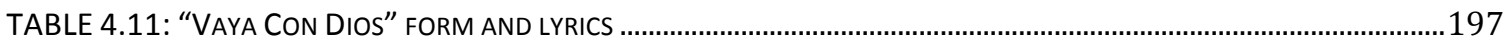




\section{List of Figures}

FIGURE 1.1 DIVERSITY OF STYLES REPRESENTED IN TOP CHARTING RECORDS OF MARY FORD, PATTI PAGE AND DORIS DAY... 13

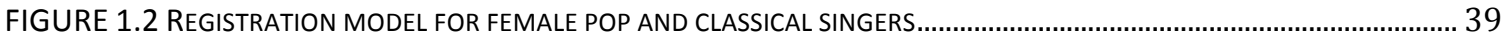

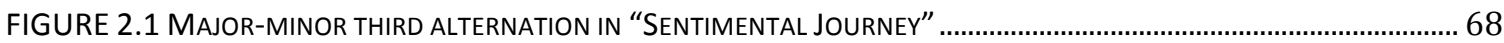

FIGURE 2.2 MELODIC EXCERPT SHOWING CLIMACTIC NOTE IN "SECRET LOVE” ................................................................... 73

FIGURE 2.3 SPECTROGRAM VIEW OF DAY'S BELTED B4 ON LYRIC “NOW” IN “SECRET LOVE”........................................... 74

FIGURE 3.1 EXCERPT OF “CONFESS” SHOWING CALL AND RESPONSE OVERDUBBING .....................................................128

FIGURE 3.2 EXCERPT OF “WITH MY EYES WIDE OPEN” SHOWING OVERDUBBED 4-PART HARMONY ................................133

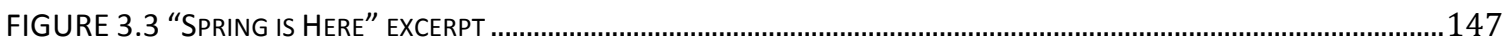

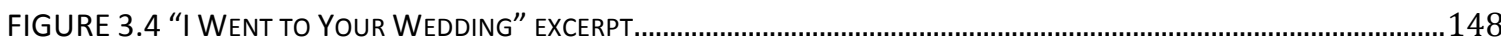

FIGURE 3.5 “I WENT TO YOUR WEDDING” SPECTROGRAM SHOWING SHIFT TO BELT TECHNIQUE........................................148

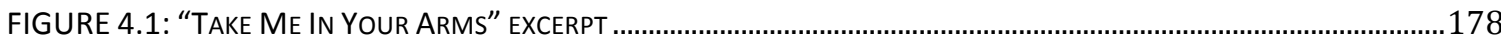

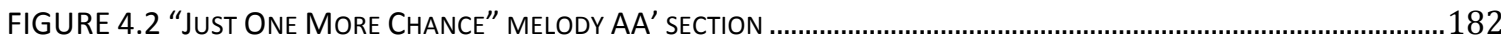

FIGURE 4.3 VOICE-GUITAR INTERACTION IN LES PAUL/MARY FORD'S “JUST ONE MORE CHANCE” ....................................183

FIGURE 4.4: MARY FORD'S SUCCESSIVE ARTICULATIONS OF REFRAIN IN “VAYA CON DIOS” ..............................................198 


\section{Acknowledgments}

I would like to thank my committee for the range of knowledge, insight and advice they have provided throughout the dissertation process: Bonnie Gordon for reminding me to keep music central to the project; Fred Maus for helping me to discover and commit to my own ideas; Scott DeVeaux for validating my interest in non-canonical pop music from Day 1; and Susan Fraiman for helping me develop my feminist voice, and for supporting me from near and far. During my coursework years, University of Virginia faculty members including Michael Puri, Ted Coffey and Eric Lott spurred my musical and cultural imagination through intensely rewarding seminars.

My graduate student colleagues have been seminal to my education throughout my time at UVa. In particular, the conversations I have had with Jason Kirby and Vic Szabo about pop music have provided me with welcome jolts of energy and inspiration. Other colleagues have been both dear friends and patient sounding-boards, among them Shana Goldin-Pershbacher, Elizabeth Lindau, Kirstin Ek, Wendy Hsu and Aurie Hsu. For her part, Allison Robbins has combined all of these roles, effortlessly rotating between offers of practical support one day, heartfelt encouragement the next, high-caliber intellectual support the next, followed by frivolous distraction on the weekends.

Finally, this dissertation would not exist without the unwavering support of my family. My father, Roy, has never stopped believing in my abilities, and has tirelessly shepherded me through the often-arduous process. My mother, Cathy, has remained a warm and wise cheerleader throughout. My sister, Emma, has given me the constant gift of herself, which includes, but is not limited to intelligence, wit, warmth, and an uncanny 
ability to understand my thoughts and experiences. She is also, and will forever be, my favorite singer. 


\section{Introduction}

Doris Day, Patti Page and Mary Ford were among a group of white female singers who gained an unprecedented presence in American popular music alongside male performers during the decade following World War II. (See table 1.) Today, these singers are largely absent from music history narratives, making it challenging to understand their historical popularity. In this dissertation, I augment our understanding of their historical success by listening closely to their most popular records. I ground my reflections and analyses in historical accounts in order to posit what pleasures they afforded their audiences. I also consider the images they presented through the print media, photos, television and film and I gauge how these images contributed to and complicated the idealized constructs of white femininity and sexuality in circulation during the postwar era.

TABLE 1 Proportion of women singers among top 10 pop music artists $1930-1960$

\begin{tabular}{|r|r|r|}
\hline \multicolumn{1}{|c|}{ Decade } & Number of women singers in top $\mathbf{1 0}$ & Percentage of women singers in top 10 (\%) \\
\hline $1930 \mathrm{~s}$ & 0 & 0 \\
\hline $1940 \mathrm{~s}$ & 2 & 20 \\
\hline $1950 \mathrm{~s}$ & 1 & 30 \\
\hline $1960 \mathrm{~s}$ & 1 & 10 \\
\hline
\end{tabular}

Source: Whitburn, A Century of Pop Music, 1999.

Note: Whitburn combines sales figures and chart performances to compile his "top artist" indices.

My study fills a gap in historical narratives of American popular music. Such narratives rarely include coverage of pop singers like Page, Ford or Day. And yet, it 
would be wrong to say that historical traces of these singers have disappeared: today thousands of their recordings exist in various formats, and easily accessible historical sources testify to their relevance to postwar popular culture. However, as long as these vocalists remain absent from official music history narratives, it remains difficult to appreciate their importance to postwar popular culture.

My study also fills a void in feminist popular music studies, or, more broadly, in the "women in music" topic embraced by feminist writers, both within and beyond academia. The "women in music" topic has grown quickly in the last two decades, as scholars and other writers have produced monographs, collections of essays, journal articles, and general interest books about women's participation in music culture. While the subjects of these publications have been diverse, there is a sustained absence of engagement with women of postwar pop.

There are several reasons for which this absence is problematic for scholarship. First, we are not currently well-equipped to characterize what was happening on the mainstream popular music charts before the advent of rock ' $n$ ' roll, neither with respect to the postwar pop genre as a whole, nor to the gender breakdown of this genre's top artists. From a feminist perspective, the absence of female postwar pop vocalists from history narratives is particularly troubling. After all, this was a stage in the music industry's history during which women did relatively well. While this feat does not necessarily deserve unabashed feminist celebration, it at least deserves acknowledgement. Admittedly, the idea of engaging with 1950s female icons may seem an uninteresting, uninspiring or even a disheartening prospect to feminist scholars. 
Postwar images of femininity can run counter to those that we tend to value in the aftermath of the women's movement of the late 1960s and early 1970s. Yet it runs counter to feminist aims to consistently ignore one group of historical women in favor of a subsection deemed a priori to be heroic or defiant.

Along these lines, my study further makes contributions to longstanding debates about musical "value," and especially the value conferred upon music that becomes part of implicit or explicit canons. In the next chapters, as I work through the music of the postwar era, the notion that this music and its singers are not "valuable" to popular music history will present itself at multiple points: the aesthetics are markedly different from what dominates today's rock and pop canons; and, the images of femininity and female sexuality seem regressive compared to what we have come to see as normal, let alone exciting, since the women's movement. My goal, however, is not to make the case that these singers are "valuable" along accepted "canonical" dimensions. Instead, I hope that my questions about these singers help to interrogate and displace the very notions of what is valuable or canon-worthy.

This project presents several tools and strategies for musical discussion of the singing voice. As many musicologists who discuss singers know all too well, it is daunting to describe the voice given the absence of codified vocabulary for doing so. However, I am fortunate to be writing during a time when voice scientists have started to work with singing pedagogues to acknowledge, qualify and even quantify different kinds of singing styles. Although these studies are far from providing a universal terminology, they provide a starting point. I draw on concepts and terminology from voice science and 
pedagogy to complement my own subjective and experience-based descriptions of the singing voice.

At times, I use an "instrumental” approach as I describe postwar pop singers' performances. Although we are correct in conceiving of the voice as distinct from other instruments because of the intimate physical connection between voice and singer, we sometimes go too far in conflating "the singer" with "the performance." This can in turn undermine our attempts at attributing musical skill and volition to the singer. I suggest that we stand to gain analytical depth in considering the singing voice as, on the one hand, an inseparable element of the vocalist's body and identity, and on the other hand, one of several possible instruments that a performing musician can "play."

\section{Chapter Outlines}

\section{Framing the Study of Postwar Pop Singers}

In this chapter, I provide a working definition for postwar pop as a genre and I introduce the primary sources that help me to arrive at this definition. I explain my rationale for choosing Doris Day, Patti Page and Mary Ford as case studies, and I provide an expanded discussion on the issues of musical canonicity and musical value I have only touched on above. After this, I outline my methodological framework and I present my approach to analyzing vocal performances. My framework draws on David Brackett's model of popular music interpretation, in combination with Philip Auslander's concept of musical persona. With respect to vocal analysis, I summarize recent research and writing 
from the voice science and voice pedagogy fields, and I lay out the terms and concepts I use in my analyses of sung performances.

\section{Doris Day: Workaround Technique, Safe Sexuality}

In this chapter, I focus on Doris Day's recordings and reception from 1945-1956, the era during which she had the most commercial success as a popular singer. I argue that although she did not have as robust a vocal technique as her contemporaries, she developed a "workaround" vocal style that rendered these lacks unimportant. Moreover, Day's customized technique allowed her to imbue her singing with an unusually vital projection of persona, rendering her singing comparable to her acting. After this, I bring Day's vocal performances and personae into dialogue with a discussion of her image across media. I argue that through recordings and through film, Day projected "safe sexuality," an articulation of sexual desire and desirability that did not challenge postwar norms of sexual propriety.

\section{Patti Page: Placid Poise, Vocal Power}

In this chapter I suggest why Patti Page may have been the top-charting pop singer of the early 1950s, moving beyond common-sense explanations that she simply radiated the “contented" mood of postwar culture. I show how historical reception of Page's recordings turned on perceptions of vocal power, versatility, and singularity. While it is true that Page projected an image of placid femininity through photographs, television and interviews, she amazed listeners with the power of her voice and her multitracked recordings. I suggest that Page's powerful singing rested in part on the "classical" attributes of her strong vocal technique. 


\section{Mary Ford: Unsung Talent, Interactive Muse}

In this chapter, I show how Mary Ford was not only a skilled vocalist, but also an exceptional and versatile musician who understood the aesthetic vision of her musical and marital partner Les Paul. I argue that Ford was central in the creation of the Paul/Ford records, though she is rarely acknowledged this way. Further, I consider the image that Ford and Paul projected as a couple, and the extent to which they reflected postwar ideals about marriage. I assess their image of coupledom as it emerges in media as well as through their records. I suggest that to the extent that Ford and Paul projected the image of happy coupledom, this image centered on romantic and sexual connection, rather than idealized postwar domesticity. 


\section{Framing the Study of Postwar Pop Singers}

This study centers on singers who sang mainstream American popular music spanning the years 1945 and 1956. In the absence of any broadly accepted genre or style name, I designate this music postwar pop. Part of the reason this repertoire lacks a wellknown label is because it was short-lived and dramatically eclipsed: in 1956, rock 'n' roll began to displace existing pop styles, and postwar pop singers quickly lost their positions as the top hitmakers of the day.

Until recently, discussions about postwar pop in music history occurred either as codas to Tin Pan Alley or swing era histories, or as preludes to the emergence of rock ' $n$ ' roll. A further confusion in trying to understand the boundaries of postwar pop is that a decade-based framework is here particularly unhelpful. Attempts to define "popular music of the fifties" are fraught, since the musical landscape changed minimally as the late 1940s rolled over to the 1950s, but dramatically around 1956-7. I therefore conceptualize postwar pop as beginning just as the swing/big big band era lost momentum after World War II, and ending in the late 1950s.

The sources that demonstrate postwar pop's existence as a genre most clearly are Billboard charts, which can be perused individually or studied in the many compendiums organized by Joel Whitburn. Whitburn's three compilations A Century of Popular Music, Pop Hits 1940-1954 and Billboard top 1000 singles, 1955-2000 are particularly helpful in showing how the music on the top of the pop charts between 1945 and 1956 forms a 
relatively continuous and homogeneous genre. This genre consists of vocal music, largely written by white songwriters, and performed by white musicians. ${ }^{1}$

Postwar pop is both continuous with and divergent from the swing era that preceded it. For example, postwar pop is connected to the Tin Pan Alley tradition, though postwar pop songs are often harmonically simpler than "golden age" Tin Pan Alley songs. ${ }^{2}$ Ballads and uptempo styles are both well-represented in postwar pop, just as they had been during the swing era. But postwar pop shows a greater range of song styles: for example, postwar pop shows a new affinity for novelty (playful, humorous, antic songs), and for "exotic" and regional allusions. And, while some postwar pop arrangements are swing band based; others use elaborate orchestration. Still others consist of novel and unusual instrumental combinations. (See table 1.1)

Meanwhile, postwar pop vocal styles remain continuous from the big band era, with a predominance of smooth and polished singing. A striking change, however, is that postwar pop records tend to revolve around a vocal performance, whereas during the swing era, a much larger proportion of hit singles contain only one vocal chorus, if they contain vocals at all.

\footnotetext{
${ }^{1}$ Joel Whitburn, Billboard Top 1000 Singles, 1955-2000 (Milwaukee, WI: H. Leonard Corp., 2001); Joel Whitburn's Pop Hits, 1940-1954: Compiled from Billboard's Pop Singles Charts 1940-1954 (Menomonee Falls Wis.: Record Research, 2002); Joel Whitburn's Pop Hits, 1940-1954: Compiled from Billboard's Pop Singles Charts 1940-1954. (Menomonee Falls Wis.: Record Research, 2002).

2 See Charles Hamm's discussion of the "third generation" of Tin Pan Alley in Yesterdays: Popular Song in America (New York: Norton, 1979), 387-390.
} 
TABLE 1.1 Style categories for postwar pop recordings 1945-1956

\begin{tabular}{|l|l|}
\hline \multicolumn{1}{|c|}{ Song style } & \multicolumn{1}{c|}{ Description } \\
\hline Sweet ballad & $\begin{array}{l}\text { Slow or moderately slow tempo. Melody is foregrounded, pulse is deemphasized, } \\
\text { rubato may be used. Arrangements may feature strings or other "sweet" } \\
\text { instrumental combinations - e.g. legato saxophones in block chord harmony. }\end{array}$ \\
\hline Rhythm & $\begin{array}{l}\text { Persistent steady groove, suitable for dancing. Until the end of the swing era (late } \\
\text { 1940s), rhythm numbers tend to "swing." As the postwar pop era unfolds, rhythm } \\
\text { numbers retain their steady pulse but lose the swing. Rhythm tunes can be slow, } \\
\text { moderate or uptempo. }\end{array}$ \\
\hline Latin & $\begin{array}{l}\text { A song that uses a Latin groove (most commonly tango, beguine or calypso.) Latin } \\
\text { tunes can be slow, moderate or uptempo. }\end{array}$ \\
\hline Country & $\begin{array}{l}\text { A song that references or appropriates the musical style or lyrical content of } \\
\text { contemporary or past country music. }\end{array}$ \\
\hline Novelty & $\begin{array}{l}\text { A song crafted purposely to stand apart from a "regular" pop song through its } \\
\text { presentation of some "novel" component, such as: a humorous conceit or set of } \\
\text { lyrics; parody or pastiche; allusions to "exotic" musics; or, the presentation of out- } \\
\text { of-the-ordinary sound worlds. }\end{array}$ \\
\hline
\end{tabular}

Note: These song style labels correspond roughly to the language used in Billboard during the years 19451956. Billboard does not provide explicit definitions of these styles, nor do its writers use the terms consistently or exclusively. I have modeled my approach to style categorization after a similar table, organizing 1943-1944 pop songs into categories, appearing in Brackett, Interpreting Popular Music, 59.

\section{Albin Zak's I Don't Sound Like Nobody: Remaking Music in 1950s America is}

the first monograph by a musicologist on postwar pop music. ${ }^{3}$ Zak helps us to understand what impulses — aesthetic, technological, economic — drove postwar music industry actors to make the kinds of records they did: these records were "not faithful documents of any existing live performance culture but artworks unto themselves created in short bursts of interaction among recording teams." ${ }^{4}$ Zak historicizes postwar pop recordings in terms of production, dispelling the notion that these records were thoughtlessly thrown together: he positions 1950s record producers as new artist-innovators who availed themselves of studio technology to create novel sounds, departing from a live aesthetic.

\footnotetext{
${ }^{3}$ Albin Zak, I Don't Sound Like Nobody: Remaking Music in 1950s America (Ann Arbor, Mich: University of Michigan Press, 2010).

${ }^{4}$ Zak, I Don't Sound Like Nobody, 8.
} 
Zak's book provides a welcome foundation for studies of the postwar pop era, exploring industry conditions and aesthetic goals of the genre's creators.

Between the 1930s and the 1950s, a preference for vocal-centered hits grew steadily. Whitburn's Billboard compilations are especially helpful in showing how vocalists fared compared to bandleaders as the most audience-favored and commercially successful acts. He combines sales figures and chart performances to compile his own "top artist" index for different years and decades, shown in tables 1.2 and 1.3. No single factor explains the shift in taste toward vocal-centered records, but music historians describe a number of possibilities. For example, Charles Hamm suggests that Bing Crosby's phenomenal success as a vocalist spurred music industry executives to offer comparable acts to record buyers. Starr and Waterman make a similar argument about Frank Sinatra. Wald connects the rise of singers to the decline of big bands, which was in turn due to Americans' shifting leisure patterns, in particular the decline of dance culture. ${ }^{5}$ The major trend is clear: from the 1930 s to the 1950 s we move from a period during which bands were favored above singers, to one in which singers are favored above bands.

TABLE 1.2 Proportion of singers to bandleaders/instrumentalists comprising the top 10 artists of the decade 1930-1950

\begin{tabular}{|l|r|r|r|}
\hline \multicolumn{1}{|c|}{ Decade } & \multicolumn{1}{|c|}{ Singers } & \multicolumn{1}{c|}{$\begin{array}{c}\text { Bandleaders/ } \\
\text { instrumentalists }\end{array}$} & Proportion of top artists who are singers (\%) \\
\hline $1930 \mathrm{~s}$ & 2 & 8 & 20 \\
\hline $1940 \mathrm{~s}$ & 4 & 6 & 40 \\
\hline $1950 \mathrm{~s}$ & 10 & 0 & 100 \\
\hline
\end{tabular}

\footnotetext{
${ }^{5}$ See, for example, Charles Hamm, Yesterdays: Popular Song in America (New York: Norton, 1979), 3867; Larry Starr and Christopher Alan Waterman, American Popular Music: From Minstrelsy to MP3 (New York: Oxford University Press, 2007), 157-8; and Elijah Wald, How the Beatles Destroyed Rock " $n$ " Roll: An Alternative History of American Popular Music (Oxford: Oxford University Press, 2009).
} 
TABLE 1.3 Proportion of singers to bandleaders/instrumentalists comprising the top 20 artists for five-year increments, 1940-1954

\begin{tabular}{|c|r|r|r|}
\hline Period & \multicolumn{1}{|c|}{ Singers } & \multicolumn{1}{c|}{$\begin{array}{c}\text { Bandleaders/ } \\
\text { instrumentalists }\end{array}$} & Proportion of top artists who are singers (\%) \\
\hline $1940-1944$ & 7 & 13 & 35 \\
\hline $1945-1949$ & 12 & 8 & 60 \\
\hline $1950-1954$ & 17 & 3 & 85 \\
\hline
\end{tabular}

\section{Selection of singers}

I have chosen to focus on Doris Day, Patti Page, and Mary Ford according to several criteria. I wanted to study women who were very popular and commercially successful during their time; whose popularity peaked in the first half of the 1950s; who projected images both through music and through additional media (film or television); and who present contrasting vocal styles and images, albeit within a genre and era that favored conformity. Whitburn's top 20 artists for the half-decade 1950-1954 helps to explain my choice of subjects (see table 1.4.)

My selection of Patti Page and Mary Ford flows directly out of these popularity figures in that theirs were the two of the most ubiquitous female voices in mainstream music in the early 1950s. Doris Day is further down the list, lying beneath three other female singers - Jo Stafford, Rosemary Clooney and Kay Starr. Yet I selected Day in the interest of accounting for very famous performers. Day's fair ranking on Whitburn's list of recording artists, when combined with her success at the box office, made her an incredibly popular all-round performer in her day, and the most well-known of these performers today. Day was the most bankable Hollywood star, male or female, during the 1950s.

Jo Stafford, Kay Starr and Rosemary Clooney certainly all deserve study by virtue 
of their successful recording careers, however they are less suited to the present study. Stafford and Starr did not have the same extra-musical media presence as the singers of my study - they did not have much of a television or film component to their careers, so their images were not as multi-media as those of the singers selected for this study.

Further reasons for my selection of Day, Page and Ford include the fact that they were experienced by listeners and described in both comparable and contrasting terms by critics, and because their outputs varied in terms of style diversity. (See table 1.5 and figure 1.1.)

TABLE 1.4 Top 20 Pop artists 1950-1954

\begin{tabular}{|c|c|c|}
\hline Rank & Artist & Gender / role \\
\hline 1 & Patti Page & Female singer \\
\hline 2 & Perry Como & Male singer \\
\hline 3 & Eddie Fisher & Male singer \\
\hline 4 & Les Paul \& Mary Ford & Male-female duo with female vocalist \\
\hline 5 & Frankie Laine & Male singer \\
\hline 6 & Jo Stafford & Female singer \\
\hline 7 & Nat "King" Cole & Male singer \\
\hline 8 & Bing Crosby & Male singer \\
\hline 9 & Kay Starr & Female singer \\
\hline 10 & Guy Lombardo & Male bandleader \\
\hline 11 & Ames Brothers & Male vocal group \\
\hline 12 & Rosemary Clooney & Female singer \\
\hline 13 & Ray Anthony & Male bandleader \\
\hline 14 & Frank Sinatra & Male singer \\
\hline 15 & Doris Day & Female singer \\
\hline 16 & Tony Martin & Male singer \\
\hline 17 & Vic Damone & Male singer \\
\hline 18 & Gordon Jenkins & Male bandleader and arranger \\
\hline 19 & Tony Bennett & Male singer \\
\hline
\end{tabular}




\begin{tabular}{|l|l|lc|}
\hline Rank & \multicolumn{1}{|c|}{ Artist } & \multicolumn{1}{c|}{ Gender / role } \\
\hline 20 & Eddy Howard & Male singer & \\
\hline
\end{tabular}

Source: Whitburn, 2002.

TABLE 1.5: Common descriptors used in the historical reception of Mary Ford, Patti Page and Doris Day

\begin{tabular}{|l|l|l|l|}
\hline & \multicolumn{1}{|c|}{ Mary Ford } & \multicolumn{1}{c|}{ Patti Page } & \multicolumn{1}{c|}{ Doris Day } \\
\hline Descriptors, ranked & 1. Warm & 1. Distinctive & 1. Moving \\
& 2. Sincere & 2. Powerful & 5. Sultry \\
& 3. Tender & 3. Moving & 5. Sexy \\
& 4. Sings with feeling & 5. Warm & 5. Warm \\
& & 5. Persuasive & 5. Throaty \\
\hline
\end{tabular}

Source: Compiled from reviews in Billboard, New York Times, Chicago Tribune, and Los Angeles Times. For the raw data, see Appendix.

FIGURE 1.1 Diversity of styles represented in top charting records of Mary Ford, Patti Page and Doris Day

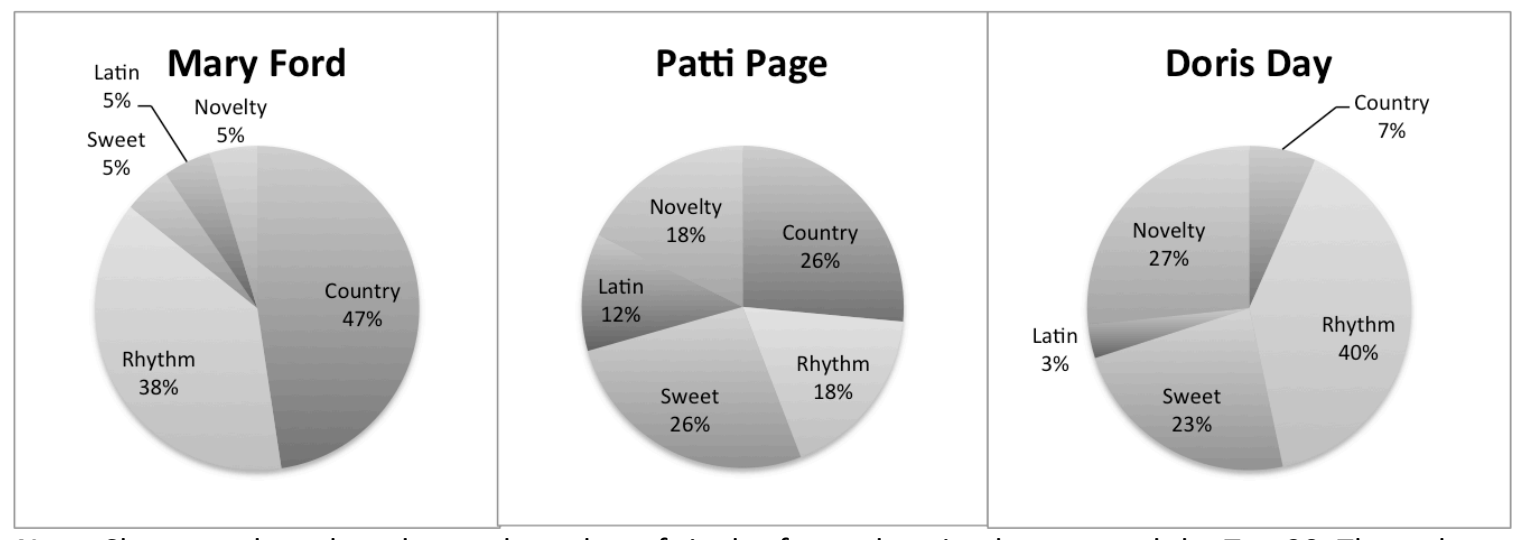

Note: Charts are based on the total number of singles for each artist that entered the Top 20. The style categorizations are my own (see table 1.1.) These breakdowns correspond to the information in tables 2.1, 2.2, 3.3 and 4.1 .

\section{Sources}

Because of the dearth of writing on postwar pop, sources on pre-rock singing in general are helpful to this study. Music historian and critic Will Friedwald focuses extensively on jazz and pre-rock singing, and his recent encyclopedia contains entries on 
Doris Day and Patti Page combining surveys of the artists' discography with some critical assessment. ${ }^{6}$ And, while Pocket Full of Dreams is about Bing Crosby, jazz historian Gary Giddins provides helpful history of singing in popular music.?

The sources on individual singers vary greatly with the singer: there is some writing on Day, little about Page, and less still about Ford. Because of her status as a top box office draw of the 1950s as well as a popular singer, Day is the subject of several biographies, the best of which is David Kaufman's Doris Day: True Story of the Girl Next Door. ${ }^{8}$ In addition, Day wrote a memoir in 1976 with the help of author A.E. Hotchner, ${ }^{9}$ who, between Day's own reflections, intersperses substantial quotes based on interviews conducted with family members, friends and coworkers. Day was the subject of the 1991 documentary Sentimental Journey ${ }^{10}$ and film writing from within and beyond academia is helpful for contemplating Day's image. ${ }^{11}$ Tom Santopietro, in Considering Doris Day, devotes a considerable length to Day's recordings, and though his musical discussion is more impressionistic than analytical it is nevertheless helpful. ${ }^{12}$

Patti Page is not the subject of any published scholarly inquiry in music, and she is rarely mentioned in accounts of popular music history. Happily, she has received

\footnotetext{
${ }^{6}$ Will Friedwald, A Biographical Guide to the Great Jazz and Pop Singers (New York: Pantheon Books, 2010).

${ }^{7}$ Gary Giddins, Bing Crosby: A Pocketful of Dreams: The Early Years 1903-1940 (Boston: Little Brown and Co, 2001).

${ }^{8}$ David Kaufman, Doris Day: The Untold Story of the Girl Next Door (New York: Virgin, 2008).

${ }^{9}$ A Hotchner, Doris Day: Her Own Story. (New York: Wiliam Morrow \& Co, 1975).

${ }^{10}$ Dick Carter and Steve Norman, Doris Day: A Sentimental Journey, Documentary, Biography, 1991.

${ }^{11}$ Molly Haskell, From Reverence to Rape: The Treatment of Women in the Movies (Chicago: University of Chicago Press, 1987); Jane Clarke and Diana Simmonds, Move Over Misconceptions: Doris Day Reappraised, BFI Dossier No. 4 (London: British Film Institute, 1980); and Dennis Bingham, "'Before She Was a Virgin...': Doris Day and the Decline of Female Film Comedy in the 1950s and 1960s," Cinema Journal 45, no. 3 (2006): 3-31.

${ }^{12}$ Tom Santopietro, Considering Doris Day (New York: Thomas Dunne Books, 2007).
} 
coverage in the work of two music writers working on "niche" subjects: music critic Karen Schoemer devotes a chapter to Page in The Great Pretenders: My Strange Love Affair with 50s Pop Music ${ }^{13}$ as does music historian Colin Escott in Roadkill on the Three-Chord Highway: Art and Trash in American Popular Music. ${ }^{14}$ The very titles of these publications demonstrate the authors' awareness that their chosen musical subjects are considered questionable: Schoemer's love affair with 1950s music is "strange" and Escott is discussing art and "trash." Happily for this study, and for popular music history, both authors conducted interviews with Page in preparing their chapters.

Patti Page has never been the subject of a biography, and until recently, the only book passing as her "memoir" was an advice guide for teenagers she published in $1960 .{ }^{15}$ Fortunately, she published a memoir four years before her death. It is short, and it lacks in depth, consistency and in features such as an index and source information, that are standard in today's mainstream publishers' biographies. Nevertheless, the memoir is an asset for scholars, and provides some invaluable anecdotes and photographs. ${ }^{16}$

Two factors make it understandable that Mary Ford has virtually no presence in writing on popular music, present-day or historical. First, Les Paul was always the spokesperson for the Paul-Ford duo; so Ford did not command any particular attention from journalists during their heyday. And second, Ford retired from the music business

\footnotetext{
${ }^{13}$ Karen Schoemer, Great Pretenders: My Strange Love Affair with '50s Pop Music (New York: Free Press, 2006).

${ }^{14}$ Colin Escott, Roadkill on the Three-chord Highway: Art and Trash in American Popular Music (New York: Routledge, 2002).

${ }^{15}$ Patti Page, Once Upon a Dream: A Personal Chat with All Teenagers (New York: Popular Library, 1960).

${ }^{16}$ Patti Page, This Is My Song: A Memoir (Bath, NH: Kathdan Books, 2009).
} 
after her divorce from Paul. She died a decade later, negating the possibility of a latter day memoir.

Les Paul as an individual commands some attention from music writers and historians. The best biography, Les Paul, An American Original is also the only source of writing of any substance on Mary Ford. Thanks to interviews with Ford's surviving relatives and early colleagues, author Mary Shaughnessy is able to provide some invaluable and otherwise undocumented details about Ford's childhood and early adulthood. ${ }^{17}$

Serge Lacasse, Peter Doyle and Albin Zak have all discussed the Paul/Ford records in terms of Paul's pioneering use of echo, reverb and overdubbing, ${ }^{18}$ and these discussions help to explain the novelty and the enormous appeal the Ford/Paul duo held for their audiences. The most sustained scholarly analysis on Les Paul and Mary Ford appears in Instruments of Desire, Steve Waksman's work on the history of the electric guitar in popular music and its successive and varying articulations of masculinity. In his chapter on Les Paul, Waksman insightfully points out the many ways that Ford and Paul's gendered images play against each other. I contribute to Waksman's discussion by considering Ford's musical role, and by conducting close analyses of the duo's recordings .

\footnotetext{
${ }^{17}$ Paul withdrew his support from Shaughnessy's project while it was underway. This seems to have had a chilling effect on the book's reception -it is now out of print. This is terribly unfortunate because it is an excellent biography.

${ }^{18}$ Serge Lacasse, “'Listen to My Voice': The Evocative Power of Vocal Staging in Recorded Rock Music and Other Forms of Vocal Expression." (Ph.D. dissertation, University of Liverpool, 2000); Peter Doyle, "From 'My Blue Heaven' to 'Race with the Devil': Echo, Reverb and (dis)ordered Space in Early Popular Music Recording," Popular Music 23, no. 1 (2004): 31-49; Zak, I Don't Sound Like Nobody.
} 


\section{Musical canons, scholarly canons, and questions of value}

There are several reasons for which the genre and the singers I study in this dissertation receive little serious attention, within and outside academia. The era of postwar pop is relatively short, and is bookended by longer, more recognizable genres: the swing/big band era that preceded and the emergence of rock ' $\mathrm{n}$ ' roll that followed. Further, postwar pop exhibits qualities of both these bookending genres: it retains aspects of swing vocal in terms of song material, arrangement and smooth vocal style. Yepostwar pop also foreshadows rock ' $n$ ' roll and rock in that it is usually singer-focused rather than bandleader-focused.

Another reason the singers and genre I study here do not receive much coverage in pop music history is that much of the scholarship on pre-rock American popular music adopts the composer as the unit of study. It is true that some scholars of American music have studied postwar pop's umbrella genre, Tin Pan Alley, in detail. However, they tend to organize this genre around notable composer/songwriters like Irving Berlin, George Gershwin and Cole Porter. The "American Popular Song” approach does not lend itself as readily to a close examination of postwar pop, because during the postwar years, no

individual composer/songwriters stood out in the same way as the most respected writers of the previous two Tin Pan Alley generations. As Charles Hamm points out, though individual songs by younger composers [in the postwar period] were sometimes fully comparable to the best of those by the great songwriters of the 1910s, '20s, and '30s, no single individual or even small group of writers dominated the third generation of Tin Pan Alley; a survey of the most successful one hundred songs on "Your Hit Parade 
(1935-58), for instance, reveals that no one songwriter was responsible for more than three of these. ${ }^{19}$

The lack of "standout" composer/songwriters in postwar pop tends to exclude this repertoire from the musicological composer-and-works model of academic study.

If the composer-as-unit is one way of selecting and organizing historical popular music in academic study that would tend to preclude postwar pop, another common direction for popular music scholarship that also denies postwar pop as an object of study is the identification of musics that we understand as resisting hegemonic forces. This approach to pop music scholarship seeks musical-historical subjects who, while belonging to less powerful social groups or communities, create music that we might read as presenting authorial agency in opposition to the forces that oppress them. For example, Elijah Wald's study of the blues offers an account of how African-Americans from the American South fashioned and refashioned blues language and blues form. Wald invites readers to recognize the blues form as the expression of agency of a racially marginalized people. $^{20}$

The search for musical subjects with agency has also shaped many studies on women in popular music: the most often studied female musicians tend to present a stance that scholars, critics and fans read as oppositional in relation to gender rules and hierarchies. For example, in Trouble Girls the contributing authors provide coverage of female rock “heroines” like Janis Joplin, Patti Smith and the Riot Grrrls, as well as prerock musicians including blues singer Bessie Smith, jazz singer Billie Holiday and early

\footnotetext{
${ }^{19}$ Charles Hamm, Yesterdays: Popular Song in America (New York: Norton, 1979), 387.

${ }^{20}$ Elijah Wald, Escaping the Delta: Robert Johnson and the Invention of the Blues (New York: Amistad, 2004).
} 
country singer Kitty Wells, all of whose music has been read as not only overcoming gendered boundaries, but also as a refutation to marginalizing forces based on race, region and class. ${ }^{21}$

Compared to the more restrictive "great-songwriters" approach to popular music, "resistance"-oriented scholarship admits a much wider swath of musicians into its realm. However, postwar pop vocalists - the subjects of my study — are usually not among them. This exclusion likely results from the fact that the postwar pop genre seems to speak for dominant social forces: its members are mostly white, and as a genre, it seems silent on issues of identity in relation to gender norms, race, sexuality and class, and in this silence, seems to be reinscribing the status quo. It therefore offers little that is compelling for the scholar seeking evidence of hegemonic resistance in popular music culture.

\section{Interventions}

The problem with the structuring themes of music discourse discussed above is that they make it challenging to discuss "mainstream" music, where "mainstream" music is the popular music that is most widely disseminated (in music sales, radio play, etc.) at any given time. Typically, academic and critical authors have deemed "mainstream" music to be unfit for serious discussion because of one or all of the following: the music is deemed to be of poor quality, it is deemed lacking in "authenticity," or it is thought to reinforce the status quo and social norms rather than push against them. As I will discuss here, though, there are many reasons why this exclusion of "mainstream" music is unhelpful, even harmful, in academic study. Fortunately, several interventions are

\footnotetext{
${ }^{21}$ Barbara O'Dair, Trouble Girls: The Rolling Stone Book of Women in Rock (New York: Random House, 1997).
} 
currently underway that promise to admit the "mainstream" musical object into study.

Intervention from feminist positions and recuperative-historical points of view are among those that have paved a way for my study. Suzanne Cusick and Susan Cook have both shown how feminist approaches to musicology require an expansion of implicit canonical boundaries of traditional musicology, because these boundaries have as one of their effects to keep women musicians out of canons, or to keep music thought to have "feminine" qualities out of canons. In her essay "Gender and Musicology," Cusick notes that the traditional frame of musicology posits that "the work itself," i.e., a piece of music written by a composer, is the seminal object for study. By restricting musicology's object of study to notated music and the authors of this notated music, we limit what we mean by "musical culture" and "musical people." For a number of reasons, women have often had more access to musical life through performing or teaching rather than composing. But achievements in performance and teaching do not make their way into typical music history narratives. ${ }^{22}$

Cusick does not address popular music scholarship in this essay, but the conceptual and real boundaries she observes in traditional musicology have a parallel in pop music studies. The entry of popular music into the realm of musicology faces obstacles similar to those that Cusick describes - those that keep women out of traditional musicology's purview. Since much popular music is never written down, or is only done so "after the fact," there is often no notated score that can serve as the object of study and analysis. And it is no surprise that Tin Pan Alley, one of the only genres of popular music

\footnotetext{
${ }^{22}$ Suzanne G. Cusick, "Gender, Musicology and Feminism," in Rethinking Music, ed. Mark Everist and Nicholas John Cook (Oxford: Oxford University Press, 1999), 471-498.
} 
that was consistently notated, enjoys a healthy scholarship in musicology. Scholarship on these composers fits neatly into traditional musicological frames: these composers wrote hundreds of songs, and they were always published as sheet music, which had the primary status as the musical object (or competed with recordings for that status).

A similar holdover of the values outlined by Cusick persists to inflect musicology's choice even of popular music performers to study, for we tend to privilege artists who create the popular music they perform over performers who "merely perform." And while this privileging is not explicitly gendered, its ramifications are: this hierarchy keeps the status of performers who are "just singers" from the ranks of acceptable and interesting objects of musicological study, certainly those in my study.

Susan Cook addresses gendered biases in the study of popular music specifically. In an article for the journal Women \& Music, Cook urges us not to promulgate the masculinist tendencies of traditional musicology as we approach popular music musicology. ${ }^{23}$ She observes that a fear of feminization exists in popular music studies; which, in turn, seems to discourage the study of popular music that does not embrace or connect to the masculinist rock aesthetic. Cook concludes that a feminist embrace of "the popular" takes seriously the use and place of music in all people's lives. It recognizes consumers as knowledgeable and discriminating musical agents as well as whimsical consumers of massmarket advertising. It recognizes that throughout history, popular music, as the feminized "one-down" position, provided a key space for the

\footnotetext{
${ }^{23}$ Susan C Cook, “'R-E-S-P-E-C-T (Find Out What It Means to Me)': Feminist Musicology and the Abject Popular," Women \& Music -- A Journal of Gender and Culture 5 (2001): 140-145.
} 
subjectivity of persons - male and female_-left out of the "classical" category of prestige. What they've made of and made in that abject space deserves our full attention. ${ }^{24}$

While Cusick and Cook present interventions from an explicitly feminist position, three subsequent works question popular music canon formation from a position that is not explicitly feminist, but that nevertheless raises related concerns. Joseph Lanza, Elijah Wald and Carl Wilson have all offered critiques against the status quo of popular music studies whereby certain genres and artists receive more scholarly and critical attention than others in ways that are not commensurate with the artists' popularity in wider society. These authors argue that scholarly and critical favorites tend to comprise artists who possess some or all of the following qualities: they participate in a blues-based or rock-based genre; they write the music they perform; they appear to stand in opposition to "commercialism"; they draw on folk or "roots" music; or, they hail from a marginalized region or ethnic/racial background. Popular music lacking in these categories then receives little attention, if not outright scorn from critics. ${ }^{25}$

Lanza coins the term "vanilla pop" to describe music that emphasizes melody as opposed to rhythm, and that tends toward smoother and lighter timbres compared to those favored in competing genres. As well as decrying the disdain vanilla pop provokes in some quarters, Lanza also suggests this disdain has disallowed the development of a helpful vocabulary with which to qualify and describe "softer" pop music:

\footnotetext{
${ }^{24}$ Cook, "“R-E-S-P-E-C-T,” 144.

${ }^{25}$ Joseph Lanza, Vanilla Pop: Sweet Sounds from Frankie Avalon to ABBA (Chicago Review Press, 2005); Elijah Wald, How the Beatles Destroyed Rock ' $n$ ' Roll: An Alternative History of American Popular Music (Oxford: Oxford University Press, 2009); Carl Wilson, Let's Talk About Love: A Journey to the End of Taste (New York: Continuum, 2007).
} 
A ["vanilla"] song like "Rhythm of the Rain"... is therefore liable to be considered "too bland" instead of delectable, "too safe" instead of mildmannered, "too lightweight" instead of soft and soothing, or "too syrupy" instead of sweet-tempered. In short, vanilla pop lacks a sufficient amount of grit and "groove" — a deficiency that shall from here on, in this book, be deemed an asset. ${ }^{26}$

Lanza then proceeds to "refocus the world's pop sensibility to the sounds, as well as to the visionary men and women, traversing the vanilla extreme."27

In Let's Talk About Love, Carl Wilson also confronts the taste profile that structures much rock criticism. As an experiment, Wilson interrogates his personal dislike of the soft-rock/pop singer Celine Dion whom he positions as the stark opposite of the rock critic's ideal artist. Wilson's self-reflexive endeavor ends up suggesting as much about why audiences are drawn to Celine Dion as it does about the biases that go into "taste" that privileges rock and related genres over pop genres. Wilson presents the notion of "schmaltz" to address the emotional register and aesthetic traits of Celine Dion's music, by which he means an unabashed presentation of sentiment. Wilson posits that while schmaltz has been embraced by audiences at every era, schmaltzy popular music ages badly compared to popular music trading in alternative affective registers: "schmaltz is an unprivate portrait of how private feeling is currently conceived, which social change can pitilessly revise. ${ }^{, 28}$ Because the social norms about what private feeling is are subject to such dramatic change, then to look back at older "schmaltz"

\footnotetext{
${ }^{26}$ Lanza, Vanilla Pop, xiii.

${ }^{27}$ Lanza, Vanilla Pop, xvi.

${ }^{28}$ Wilson, Let's Talk About Love, 61.
} 
might be more off-putting or alienating than listening back to older material that foregrounds alternate features or affects.

In How the Beatles Destroyed Rock 'n' Roll, Elijah Wald starts with the same acknowledgment about the lack of balance in popular music criticism, but Wald uses this as a springboard for a more thorough history of twentieth century American popular music. Wald argues that typical popular music histories have focused on critical favorites rather than audience favorites; his response, then, is to write a history of audience favorites rather than critical favorites. Wald argues that many musicians and music consumers participate in music culture with little to no investment about what is groundbreaking but instead with an affinity for what is pleasurable, fun, or danceable.

\section{Building on the interventions}

My project dialogues with all of these interventions, because the artists and the music I study belong to all of the categories that concern the authors above. The music I study is sung by women who are "just performers," and therefore is not associated with the musical greatness more commonly attributed to composers or to "the music itself." The music I study sits on what Cook would call the "softer" side of popular music; it is distant from rock aesthetics, and therefore risks being overlooked in favor of historical genres such as 1950 s rhythm and blues or 1950s country. The postwar pop of my study is certainly "vanilla," according to Lanza's scheme, and much of it exudes direct expressions of sentiment - in other words, it is "schmaltzy," according to Wilson's definition.

Although the postwar pop genre as a whole is ripe for extensive academic 
investigation, I choose to focus on its female singers for at least two reasons: first, to fill gaps in the existing narratives of women and popular music, and second, because of the intriguing peak in the participation of women in pop music during this era. While my project answers calls of both feminist and "canon-revisionist" authors, there is perhaps a last-bastion challenge that I face as a feminist musicologist addressing Doris Day, Patti Page and Mary Ford: I am studying female singers of "schmaltz" who do not generally exude signs of rebelliousness or subversion. I do not undertake this study with an a priori goal of finding hidden, "resistant" and therefore feminist-positive meanings within their performances. This would seem to put me in dangerous feminist territory: could it not be the case that directing my attention to women singers who do not seem to disrupt or threaten the status quo, during a period that is known for its particularly stark gender role opposition, is a de facto anti-feminist undertaking?

Again, I take my cue from Cusick and Cook, who both urge that opening the boundaries to musicology and popular music studies is a way of according respect to all people more equally, both musicians and listeners. I am interested in musicians, music, music audiences, and music in history. Although in my leisure time I enjoy to listening music I "love" or consider "great," I'm equally interested in the music that other people "love," or consider "great," or even the music they simply play in the background. As a feminist, my major contribution in this project is to notice and to care that a large number of women were commercially successful during a short time span in the American mainstream music industry; and to wonder how and why they appealed to their audiences. 


\section{Interpreting music, constructing personae}

In the absence of contemporary scholarly discussion devoted to interpretation of postwar pop, I shape my study in part by "conversing" with the professional music writers and critics who engaged with the genre on a daily basis. In Interpreting Popular Music, David Brackett models by example strategies for the "interpretation" of historical popular songs. He uses the word "interpretation" over "analysis" advisedly: analysis is "the discussion of how the parts relate to one another," and interpretation the process of discovering "what is the effect and meaning of these 'parts' or, for that matter, the 'whole." Brackett suggests that the practice of "interpretation"-while in some ways individual and idiosyncratic — is rarely completely lacking in generalizability: this is why certain artists or songs are consistently met with certain interpretations over others. ${ }^{29}$

I benefit from at least three facets of Brackett's model. The first has to do with the analytical approach to the recordings themselves. Brackett notes that unlike art music, which often repays an engaged study of harmony, popular music invites a more careful analysis of "surface." He suggests that, rather than producing full transcriptions of pop songs, it is often sufficient to provide partial transcriptions of areas of interest. In these transcriptions we may want to pay special attention to vocal performance-considering melody, rhythm and timbre — and note how it relates to the songs lyrics, harmony, or instrumental arrangement.

The second helpful part of Brackett's interpretation model involves reconstructing the relevant historical-musical field. This consists of answering questions such as: what songs did this one "compete" with? What is the song's genre, and does the genre itself

\footnotetext{
${ }^{29}$ David Brackett, Interpreting Popular Music (Berkeley: University of California Press, 1995), 201.
} 
convey meanings or associations across songs? What are the song's precursors, and what are the relationships between them? And finally, Brackett helpfully models strategies for interpreting different kinds of discourse around the song and the singers - this in order to avoid uncritically (or unwittingly) eliding biographical commentary about the artists with their work. In my project, I take care to separate types of reception and critical discourse in this project. Biographical writing belongs to one track; historical press to another; and contemporary writing to yet another. I do not disallow these discourses to inform each other but I always consider their different provenances, aims and audiences.

\section{Postwar personae, historical images}

Although Brackett accords some attention to "the problematic aspects of "authorship" in popular song," 30 he does not extensively theorize on how a performer's image and performance become intertwined. The notion of "musical persona" expounded by Philip Auslander is therefore a helpful addition to Brackett's model. In his goal of developing a "performer-centered theory of musical performance," ${ }^{31}$ Auslander presents the notion of musical persona as "a performed presence that is neither an overtly fictional character nor simply equivalent to the performer's 'real' identity." 32 Auslander analyzes different performers from different musical genres, and notes how several factors come together to create musical persona. The musical work and the performer's musical style join appearance and manner in addition to what Auslander calls setting: the norms and conventions that characterize the listening experience. All these elements contribute to the musician's persona, which, while negotiated through every performance, remains

\footnotetext{
${ }^{30}$ Brackett, Interpreting Popular Music, 14.

${ }^{31}$ Philip Auslander, "Musical Personae," The Drama Review 50, no. 1 (March 1, 2006): 103.

32 Auslander, "Musical Personae," 102, note 5.
} 
somewhat stable between performances. ${ }^{33}$ Another important dimension to Auslander's model is that musical persona develops in relation to an audience; it is not just a unilateral construct of the individual performer. Audiences, he suggests, "try to make performers into who they need them to be, to fulfill a social function." 34

I adapt Auslander's model of persona in my study in positing that each of the singers presented personae in their performances, and that these personae rested between the singers" "real' identity" and the overtly fictional characters of their songs. To reconstruct these personae, I consider song material and performance manner alongside extra-musical material that was concurrently in circulation. Building these personae helps me to relate these singers' popularity to ideals and norms circulating in society without having to make unverifiable claims about biography, nor having to start over and consider each new song a blank slate for the presentation of identity. Having said this, I do grant that some singers show more variation in persona than others. In the following chapter, I discuss three distinct vocal personae for Doris Day, which I label "sexy/sultry," "tender," and "sunny." Mary Ford presents a discreetly sexual persona in certain ballads; for many other songs I hear the projection of persona as emerging from Les Paul and Ford together so that they project a "couple persona." Finally, I agree with many current observers that Patti Page tends to present a rather uniformly "warm" persona across songs. Since this persona is a less dynamic aspect of her output, I focus less on Page's persona, and more on her vocal technique.

\footnotetext{
${ }^{33}$ Auslander, "Musical Personae," 118.

${ }^{34}$ Ibid., 115.
} 
Related to the concept of persona is the broader term "image" which I also use frequently. "Persona" and "image" overlap but are distinct. I use persona when I talking about emergent aspects of the singer that are specifically person or personality-related. Whereas the term "image" I use more broadly to mean "a concept or impression, created in the minds of the public."35

Equipped with interpretive models, I then combine close readings and "broad readings" of the singer's recordings, I survey historical reception coinciding with their popularity, I conduct close readings of selected non-musical media texts, and I posit what kinds of personae and what kinds of pleasures Day, Page and Ford offered through their music.

In order to understand what kind of language was used and what kinds of themes and ideas surrounded discussions of these singers during their time, I survey one music trade magazine and four national daily newspapers comprehensively for the years 1945 1960. These include Billboard, The New York Times, The Chicago Daily Tribune, The Washington Post and The Los Angeles Times. In addition to these comprehensive surveys, I also use articles from DownBeat, Metronome, Life, Time, Saturday Evening Post and TV Radio Mirror.

\section{The study of (postwar pop) singing}

There are at least three major challenges I face in giving a prominent place to vocal performances in a study of popular music. The first is that there is little codified vocabulary to describe the singing voice within musicological discourse. While writers

\footnotetext{
35 “Image, n.," OED Online (Oxford University Press, September 2013), accessed October 14, 2013).
} 
are often moved to write evocative, poetic descriptions of voice using metaphors for other senses ("bright," "dark") or describing the affect of the singer or the affect she elicits in listeners ("sad", "rousing"), there is little understanding about what technical aspects of voice production create what kinds of sounds, nor of the acoustic properties that may warrant our designating one voice dark and another bright, for example. While I do not want to undercut the usefulness and sometimes-sufficient extent of metaphor or emotionbased description of vocal performance, I believe it is useful in a study such as this to begin to engage with pedagogical and scientific literatures, which address the singing voice in more systematic ways.

The next challenge is that insofar as I do want to describe the singers of this study with technical vocabulary when appropriate, I am limited in terms of what I can determine with certainty. A comprehensive understanding of a singer's voice and her technical abilities would come from an opportunity to hear her across multiple performance contexts, both live and recorded. Self-reporting can also be helpful in teaching us about a singer's voice, but these kinds of reports are usually limited if they exist at all. Both Day and Page talk about their singing in their memoirs. For Day, especially, this has helped me glean her approach to technique. I have not encountered any texts in which Ford describes her approach to singing.

I make use of Sonic Visualiser, a software program designed for musicologists allowing us to view the audio data contained within recordings. ${ }^{36}$ While enormously

\footnotetext{
${ }^{36}$ Chris Cannam, Christian Landone, and Mark Sandler, "Sonic Visualiser: An Open Source Application for Viewing, Analysing, and Annotating Music Audio Files," in Proceedings of the ACM Multimedia 2010 International Conference (presented at the ACM Multimedia 2010 International Conference, Firenze, Italy, 2010.
} 
helpful, this software is far from a "total explanation" for the singing voice. ${ }^{37}$

Yet another challenge is that while I can avail myself of new voice research and writing about the singing voice, these studies rarely touch on singing styles resembling postwar pop singing. ${ }^{38}$ When scientists and pedagogues do look beyond classical singing style, they turn in large numbers to the singing style known as belting. However, the singers of my study use belting technique only occasionally, if at all.

The first body of literature I draw on is from voice science literature: this is research conducted by scientists with backgrounds in physics, acoustics or anatomy, and who have become experts on the voice and the singing voice in particular. Scientists who write on the voice use a combination of techniques: often, they combine precise understanding of human anatomy with measurement of different anatomical and acoustic data while singers sing. In addition, some of these scientists work with computer models to predict voice behavior and sound production under different conditions. I have drawn extensively on articles published between 2000 and the present, appearing in the Journal of Voice. $^{39}$

${ }^{37}$ Because Sonic Visualiser provides a visual corollary of all of the audio information in a recording, it does not depict the singer's voice as it emanates from her body, but rather the audio information about her voice that was captured in the recording. Issues like microphone placement, balance between voice and accompaniment, voluntary audio effects like reverb or any other manipulations engineers or final mix masters might have made to the final recording, and involuntary noise aspects to the recording all have the potential to affect what I read on the program as audio information coming from the voice.

${ }^{38}$ This is probably because for the most part, this postwar pop singing style has died out. The postwar pop singing style went out of fashion with the advent of rock; and few recording artists today sing in the way that the postwar pop singers did.

${ }^{39}$ The following Journal of Voice articles have been the most helpful: HK Schutte and DG Miller, "Belting and Pop, Nonclassical Approaches to the Female Middle Voice: Some Preliminary Considerations," Journal of Voice 7, no. 2 (June 1993): 142-50; Eva Björkner, "Musical Theater and Opera Singing-Why So Different? A Study of Subglottal Pressure, Voice Source, and Formant Frequency Characteristics," Journal of Voice 22, no. 5 (September 2008): 53; Christopher Dromey, Lorie Reese, and J. Arden Hopkin, "Laryngeal-Level Amplitude Modulation in Vibrato," Journal of Voice 23, no. 2 (2009): 156-163; and Amy Lebowitz and R. J. Baken, "Correlates of the Belt Voice: a Broader 
The second body of literature on the voice I engage with is by voice teachers, researchers and academics associated with the National Association of Teachers of Singing, and its Journal of Singing. In 2003, vocalist/pedagogue Jeanette Lovetri published a landmark article for the journal in which she coined the term contemporary commercial music (CCM) to encourage discussion of singing beyond western classical traditions. $^{40}$

Lovetri and other professionals who publish in Journal of Singing have at least a basic familiarity with the work of the voice scientists, so the two literatures coincide helpfully: voice scientists have become more interested in studying singing styles outside of the classical realm, and singing pedagogues who publish often possess at least rudimentary knowledge of the latest voice science. Sometimes voice researchers from the two fields collaborate. ${ }^{41}$

Despite the helpful results from these two fields' advancements, we are yet far from universal understanding or accepted codification of vocal concepts and singing phenomena. Disagreement between and within the two communities limits our ability to simply "peel off" their terminology and findings. Furthermore, the goals of science and pedagogy are different from each other, and different from those of most music scholars. Scientists test theories and use extreme caution and precision when making conclusions. For their part, pedagogues have long been used to working in a realm in which precise

Examination," Journal of Voice 25, no. 2 (2011): 160-165.

${ }^{40}$ Jeannette L. Lovetri, "Contemporary Commercial Music: More Than One Way to Use the Vocal Tract," Journal of Singing 58, no. 3 (January 2002): 249-252.

${ }^{41}$ For example, as of the time of this writing, Lovetri is active in vocal pedagogy, and she is also on the faculty of the Drexel University College of Medicine where she works with the Otolaryngology department. 
knowledge of the voice apparatus is not always available or even necessary to achieve good pedagogical results. Nevertheless, these two literatures do yield enough commonalities to provide a base upon which I can build reasonable musicological interpretations.

While there are a multitude of singing styles that communities across the world have developed, until recently, the authoritative writing on singing in the West tended to center on classical singing, implying that non-classical singing styles are any or all of: less complicated, less interesting, less skilled, less "natural," less healthy, morally suspect, or even unworthy of being called singing.

Lovetri and others writing in the Journal of Voice have moved to end this bias, and though Lovetri does not claim that CCM styles resemble each other, she suggests that they do share in common that for the most part they are closer to the speaking voice. Whereas, continuity with the speaking voice is not the case (or the goal) with classical singing. ${ }^{42}$

Most of the new research on female singing outside of the classical arena has focused on the technique known as belting. While this is certainly an advancement, there are now so many studies on belting, and so little progress in other popular vocal styles, that one would have the impression that all female singers are either classically oriented or full-time belters. There are a few exceptions: Lovetri provides a brief explanation of “crooning” which may apply to the singers in my study; and Laura Anne Bateman's study covers a wide series of vocal styles (classical, belt, pop, "legit", jazz, country and r

\footnotetext{
${ }^{42}$ Lovetri, "Contemporary Commercial Music," 249.
} 
\& b. $)^{43}$

\section{"Register" in the female singer}

A discussion of "register" in singing can engender confusion before the

discussion even gets underway. This is in part because the term is used to mean different things: as James McKinney notes, it can be used to denote: “(a) a particular part of the vocal range (upper, middle, or lower register), (2), a resonance area (chest or head) (3) a phonatory process (4) a certain timbre and (5) a region of the voice which is defined or delimited by vocal breaks. ${ }^{44}$ I will be using Manual Garcia’s definition of register: a "consecutive series of tones that share both same mechanical production and same basic timbre. ${ }^{45}$

Discussion of register in singing can also become confusing if commentators generalize across male and female singers, or across singing styles. In fact, register manifests itself differently for men and women in both classical and non-classical styles; and registration for women has different implications in classical singing compared to pop singing.

There is no firm agreement on how many registers there are in the singing voice: Tracy Bourne proposes that are two basic vocal mechanisms for producing sound ${ }^{46}$ Ingo

${ }^{43}$ Jeannette LoVetri, "Voice Pedagogy: Female Chest Voice," Journal of Singing 60, no. 2 (November 2003): 163; Laura Anne Bateman, "Soprano, Style and Voice Quality: Acoustic and Laryngographic Correlates" (Master of Arts Thesis, University of Victoria, 2003), 32-41.

${ }^{44}$ James McKinney, The Diagnosis and Correction of Vocal Faults: A Manual for Teachers of Singing and for Choir Directors (Long Grove, IL: Waveland Press, 2005), 93, cited in Elena Blyskal, "The Female Primo Passaggio: A Survey of Its Physiology, Psychology, and Pedagogy," Journal of Singing 69, no. 1 (2012): 12.

${ }^{45}$ Nathalie Henrich, "Mirroring the Voice from Garcia to the Present Day: Some Insight into Singing Voice Registers," Logopedics Phoniatrics Vocology 31, 3 (2006), cited in Blyskal, "The Female Primo Passaggio," 12.

${ }^{46}$ Tracy Bourne, Maeva Garnier, and Diana Kenny, "Music Theater Voice: Production, Physiology and 
Titze suggests there are three such processes ${ }^{47}$ and Bateman surmises there may be as many as five. ${ }^{48}$ Despite this lack of unity, there is general agreement that men and women have at least two vocal registers, one responsible for a heavier sound and one for a lighter sound. The heavier is sometimes connected to the terms "chest" or "modal," and the lighter to the terms "head" or "falsetto." There is also agreement between pedagogues and scientists that these two sounds correspond to two sets of vocal fold behavior: for the heavier sound, the vocal cords are thicker and shorter, and for the lighter sound, they are thinner and more stretched. ${ }^{49}$

Part of the disagreement may result from semantics and the process of categorization: what one researcher may conceive of as two distinct modes of vocal fold behavior, another might construe as variation within one mode. Another source of disagreement could come from lack of communication between pedagogues and scientists, and yet another, from the failure to account for differences between genders and between singing styles. ${ }^{50}$

Based on my review of the literature, I support the conceptualization of at least three registers in the female singing voice. I draw largely on the work of Bateman who applied her years of experience teaching singers in both classical and theatre-belt singing styles to her graduate work in voice science. Bateman marks the difference between the "thick" and the "thin" mode of vocal fold behavior; but she further subdivides the thin

Pedagogy," Journal of Singing 67, no. 4 (2011): 440.

${ }^{47}$ Ingo R. Titze, "The Human Instrument," Scientific American, January 2008.

${ }^{48}$ Bateman, "Soprano Style and Voice Quality," 23-4.

${ }^{49}$ For an entry-level description of vocal mechanism with helpful illustrations, I recommend Titze, The Human Instrument.

${ }^{50}$ Because of the gender differences in vocal apparatus and vocal quality, all of my subsequent discussion centers on female singing only. 
mode into two groups: in the first, the whole vocal fold muscle vibrates; and in the second, only the ligament of the vocal fold vibrates, while the muscle stays taut. Bateman terms these three modes Modal Voice, Testo Voice, and Falsetto. (See table 1.6)

Although I draw on Bateman's registration model, I use different terminology from hers. Bateman deliberately uses "modal" and "testo" in place of "chest" and "head" because of the confusion this second pair of terms has at times engendered. ${ }^{51} \mathrm{I}$ acknowledge this confusion, but I prefer to retain "head" and "chest" because they are more familiar, and I qualify "head" as either "low head" or "high head" (see below) in order to minimize the confusion. I have also extrapolated from Bateman's work to hypothesize about how female classical and popular singers use the different registers.

Often, when classical female singers talk about a transition in register, they are referring to a change that occurs in both in their timbre and voice production mechanism that occurs as they ascend in pitch, taking place somewhere between C5-F5. (See figure 1.2.) Sometimes these singers refer to moving into their "head voice" to describe this. It is also called passaggio or second passagio. Bateman would likely describe this as a registral change from testo voice to falsetto.

Meanwhile, female pop singers rarely sing above C5. Their most important registral transition occurs around E4-A4. This is the range at which a female singer has to apply more tension to the vocal apparatus to keep the vocal folds in their short, thick shape - in other words, to keep singing in "chest voice." A pop singer who releases the

\footnotetext{
${ }^{51}$ Part of the confusion around the terms "head" and "chest" is that they can mistakenly suggest that sound is "produced" in the head or chest. In fact, all vocal sounds are produced in the larynx. The terms "head" and "chest" may stem from the fact that singers feel sympathetic vibrations in their bones and tissues in the head and chest areas.
} 
vocal cords from this tense, short, thick formation and proceeds to sing with the vocal cords in a thinner, more stretched shape will often speak of leaving her "chest voice" for her "head voice," even though this pop singer head voice will not sound like the classical singer's head voice used for pitches C5 and above. This means that "head voice" is potentially used to describe two different ranges and vocal mechanisms: one for classical and one for popular female singers.

It is for this reason that I have coined the terms "low head voice" and "high head voice" as substitutes for Bateman's categories of the testo voice and falsetto voice. (See table 1.7.) These terms are not perfect, but I hope that by distinguishing low head from high head that I can both draw on the familiarity of the term "head voice" but also qualify as "low" to distinguish from a classical singer's highest range.

This breakdown is especially helpful for me because postwar vocalists contrast greatly from most contemporary female singers in rock and pop music, many of who sing only in chest register. ${ }^{52}$ It is partly this contrast that makes postwar pop singers so distinct from today's female pop and rock singers. Postwar pop singing, with its smooth transition between a comfortable chest register delivery and a comfortable low head delivery shares something with classical singing aesthetics: like classical singing, much postwar pop singing prioritizes the illusion of effortlessness, which in turn is helped by a smooth register transition. In contrast, much of today's female pop and rock singing makes audible and desirable a sense of vocal reaching or even strain, which can be read by listeners as the communication of intense emotion.

\footnotetext{
${ }^{52}$ Lovetri, "Contemporary Commercial Music," 251.
} 
TABLE 1.6 Bateman's proposed vocal register and mechanism categories for the female voice

\begin{tabular}{|l|l|l|l|}
\hline \multicolumn{1}{|c|}{ Register } & \multicolumn{1}{|c|}{ Vocal action/mechanism } & \multicolumn{1}{c|}{ Tone } & \multicolumn{1}{c|}{ Usage } \\
\hline $\begin{array}{l}\text { Modal } \\
\text { voice }\end{array}$ & $\begin{array}{l}\text { Vocal folds “thick," i.e. in cross } \\
\text { section are square-shaped }\end{array}$ & Robust & $\begin{array}{l}\text { (1) All low pitched singing } \\
\text { (2) May be used at higher pitches } \\
\text { in belt style }\end{array}$ \\
\hline $\begin{array}{l}\text { Testo } \\
\text { voice }\end{array}$ & $\begin{array}{l}\text { Vocal folds "thinner," i.e. in } \\
\text { cross section they are } \\
\text { triangular-shaped }\end{array}$ & Pure & $\begin{array}{l}\text { (1) Classical middle register } \\
\text { (2) May be used for high register } \\
\text { belting }\end{array}$ \\
\hline Falsetto & $\begin{array}{l}\text { Vocal folds "thinner," i.e. in } \\
\text { cross section they are } \\
\text { triangular-shaped, and only the } \\
\text { ligament of the larynx vibrates }\end{array}$ & $\begin{array}{l}\text { Extremely } \\
\text { pure }\end{array}$ & $\begin{array}{l}\text { Classical singing above second } \\
\text { register break }\end{array}$ \\
\hline
\end{tabular}

Source: Bateman, “Soprano Style and Voice Quality," 23-24.

TABLE 1.7 Adapted terms for and hypothesized usage of vocal register and mechanism categories for the female voice

\begin{tabular}{|l|l|l|l|}
\hline $\begin{array}{c}\text { Register } \\
\text { (my term) }\end{array}$ & $\begin{array}{c}\text { Register } \\
\text { (Bateman's } \\
\text { term) }\end{array}$ & \multicolumn{1}{|c|}{$\begin{array}{c}\text { Use in classical } \\
\text { singing }\end{array}$} & \multicolumn{1}{|c|}{ Use in popular singing } \\
\hline Chest voice & Modal voice & $\begin{array}{l}\text { Used only for the } \\
\text { lowest range, and/or } \\
\text { occasionally for } \\
\text { expressive purposes } \\
\text { Rarely used above C4 }\end{array}$ & $\begin{array}{l}\text { Used regularly by singers with intense, "chesty" } \\
\text { singing styles; includes many contemporary rock } \\
\text { and pop singers; and much contemporary music } \\
\text { theatre singing. Used for (but not synonymous } \\
\text { with) belting. Chest-register dominated singers } \\
\text { may push this mechanism as high as C5. }\end{array}$ \\
\hline $\begin{array}{l}\text { Low head } \\
\text { voice }\end{array}$ & Testo voice & $\begin{array}{l}\text { Used regularly } \\
\text { between C4 and C5 }\end{array}$ & $\begin{array}{l}\text { Used by some music theatre singers for pitches } \\
\text { above F4. (Sometimes called "faux belt.") } \\
\text { Used by popular singers with smoother, lighter } \\
\text { tones, including postwar pop singers }\end{array}$ \\
\hline $\begin{array}{l}\text { High head } \\
\text { voice }\end{array}$ & Falsetto & Used for C5 to C6+ & Used rarely. \\
\hline
\end{tabular}




\section{FIGURE 1.2 Registration model for female pop and classical singers}

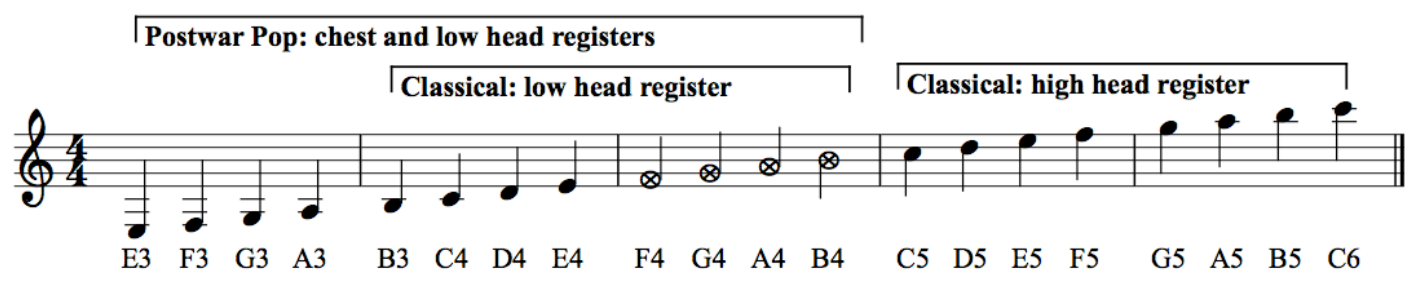

Note: The pitches F4-B4 (marked by " $\mathrm{x}$ " noteheads) are the crucial pitches that distinguish belting from relaxed pop singing. (Or to put in other terms, to distinguish modern chest-register driven pop/rock singing from much postwar pop singing.) When singers use chest voice up to $E 4$, the tone tends to sound relaxed. To preserve the aesthetic of relaxation, a postwar pop singer may switch into low head register for the pitches F4 and upward. If, on the other hand, a singer retains chest voice for F4 upward, the sound becomes more intense, and sometimes there is a more of a perceptible sense effort, even strain.

\section{Vibrato}

In both classical and popular singing spheres, vibrato refers to a quick oscillation in pitch, and to a lesser extent, intensity, manifested on a sustained sung pitch. A note sung with vibrato is commonly experienced by the listener as a single sustained pitch, despite the pitch oscillation. Perhaps because vibrato is in some ways more tangible than timbre, it often draws commentary from music writers - who might remark, for example, on a singer's "use of vibrato," or her "fragile vibrato" or her "heavy vibrato." While it is useful to note and reflect on the type and extent of vibrato in a sung performance, some of the commentary on vibrato does not coincide with either performers' or scientists' accounts of the phenomenon.

Although the understanding of vibrato is far from exhaustive, voice scientists have proposed a theory that accounts at least for the phenomenon in classical singing: it is an involuntary, secondary effect of the tension between two opposing sets of vocal 
muscles in the larynx known as the $\mathrm{CT}$ and TA group. ${ }^{53}$ The theory holds that when classical singers achieve an efficient balance between the two muscle groups in the production of a given pitch, the muscle groups "twitch" in regular pulses rather than remaining stiff as a way of preventing fatigue. This in turn causes a slight oscillation to the frequency, and less so, to the intensity. Although this phenomenon is involuntary, it is absolutely desirable in many singing styles. In classical singing, regular and consistent vibrato is the sign of good technique and has come to be experienced as a desirable aspect of the singing voice. This coincides with most classical singing teachers' position on vibrato: it does not need to be explicitly "taught," for it almost always develops as a result of increased coordination of breath and phonation. For many singing teachers, vibrato is a sign that things are going right. ${ }^{54}$ There is far less research on vibrato in nonclassical styles; neither scientists nor pedagogues have considered this issue in any depth. ${ }^{55}$ However, it is clear to me from listening to sound and from viewing Sonic Visualiser spectrograms that all postwar pop singers use at least some vibrato, and all occasionally use straight (i.e. vibratoless) tone. The extent and quality of vibrato changes drastically across singers, as well as within an individual's own repertoire. Some postwar pop singers' vibrato bears resemblance to the vibrato profile of classical singing in its ubiquity and quality; and this similarity suggests that for these singers, the vibrato may be a secondary effect of relaxed sound production not unlike that espoused in classical technique. Other singers' vibrato is so different from classical vibrato that it is

\footnotetext{
${ }^{53}$ Gayle Walker, "Vibrato, Science, and the Choral Singer," Choral Journal 47, no. 6 (December 2006): 36-46.

${ }^{54}$ Walker, "Vibrato, Science and the Choral Singer," 36.

${ }^{55}$ Christopher Dromey, Lorie Reese, and J. Arden Hopkin, "Laryngeal-Level Amplitude Modulation in Vibrato," Journal of Voice 23, no. 2 (2009): 156.
} 
reasonable to assume it results from different mechanisms. Vocal pedagogue Karen O'Connor lists "induced" vibrato forms such as abdominal or laryngeal means. ${ }^{56}$

While I am limited in my ability to know exactly how the singers of my study are producing their specific sounds, I can use my observation of vibrato-obtained through listening and spectrogram images - in two ways: first, to bolster my hypotheses about the voice mechanism being used at a specific point, and second, to observe connections between singers' use of vibrato and reception. For example, Patti Page's wide, consistent and near-ubiquitous vibrato suggests she is using some aspects of classical technique; this corresponds to other dimensions of her vocal style, such as consistent timbre, and long legato lines. Doris Day's vibrato is in more rapid and intensity-based. Page is often deemed a "powerful" singer, and Day, while praised for her singing in many ways, is never deemed a "powerful' singer.

In this study, I will treat vibrato as a part of a singer's technique, or as the involuntary but desirable offshoot of technique. I do not interpret vibrato as an unmediated, essential quality of emotions that simply exude from the singing person. This is why I do not find helpful phrases such as "fragile vibrato" since they conflate two distinct phenomena. Vibrato is a result of technique, and is best described with more objective descriptors: wider, narrower, faster, slower, more present, less present, more consistent, more wavering. In contrast, affective qualities exuded by the singers result from the sum total of her performance choices (as well as the material and the arrangement); and while it may contribute to this sum total, vibrato is not a special

\footnotetext{
${ }^{56}$ Karen O'Connor, "Vibrato: What it is and How to Develop It," Singwise, http://www.singwise.com, accessed June 15, 2012.
} 
conduit that projects the singer's "self" directly into the audible ether.

\section{Female postwar pop singing}

I can now present some general comments and vocabulary that will help in my discussion of postwar pop singing. A first piece of vocabulary I present is one I coin for the purposes of this dissertation: relaxed pop singing. I use this term to describe the most common vocal style that the female postwar pop singers of this study use. I define relaxed pop singing in women singers as follows:

- A popular and well-received vocal style characterizing the singing of many of the top female postwar pop singers - not only Day, Ford and Page, but also Dinah Shore, Jo Stafford, and Rosemary Clooney, among others.

- A style of singing that usually sounds relaxed, as if it does not require much effort

- A style of singing that allows for very clear articulation of words, and for a diction/pronunciation that retains many of the characteristics of spoken English

- A style in which the timbre retains a speech-like quality across much of the sung range; this is in part aided by song material that does not stray far from a woman's comfortable speaking range, i.e. G3-F4

- A style that is produced by using a combination of chest register and low-head register, transitioning from one to the other smoothly and usually without an audible break

- A limited use of belt, i.e. the technique whereby chest voice is pushed to G4 and above, resulting in an intense, sometimes brassy tone.

Moving past these general style traits, we can then start to differentiate between postwar 
pop singers and establish some tendencies and techniques that differentiate them. For example:

- Breathiness: Doris Day and Mary Ford introduce significant breathiness into their tone, especially in the low end of their registers

- Timbre variation vs. timbre consistency: Doris Day varies her timbre within and across songs; Mary Ford varies her timbre across songs, but less so within; and Patti Page (as well as others like Dinah Shore and Jo Stafford) maintain fairly consistent singing timbres within and across songs.

- Country "twang": Certain singers use a country "twang" in some of their songs. This goes both for singers who were brought up speaking with some kind of southern accent— this includes Ford and Page; but also it is also something that most singers can "turn on and off" at will. ${ }^{57}$

- "Classical" technique: breath and vibrato: All singers using the relaxed pop style sound relaxed to some degree or another. But a subset of these uses an adapted form of classical technique in regard to breath and relaxed tone production. On some songs, Page demonstrates considerable breath control, coupled with a wide vibrato initiated at onset of long notes - these are both elements more common to classical than pop singers. For the listener, this can sound like the singer has endless breath, and that the sound is flowing out effortlessly; and in fact, classical voice production is a more "relaxed" activation of the vocal apparatus, and the singer can do more (sing longer and

\footnotetext{
${ }^{57}$ Bateman notes several physical correlates of "twang" in the singing voice, including a high larynx position and constriction of the pharyngeal walls. "Soprano, Style and Voice Quality," 40.
} 
louder) with less (less tension in the vocal apparatus), so the listener is

"correct" in hearing this kind of singing as extra-relaxed

As a last note on terminology: two terms I considered using but decided against are "crooning" and "legit" (short for "legitimate.") Crooning has been mostly applied to male singers, but inconsistently so. Therefore my adoption of this term would not help my study. ${ }^{58}$ The term "legit" as used in the music theatre world does share many of the qualities of postwar pop singers, but again, it seems unhelpful to use a term that arose out of, and that resides mostly within a music sphere to which postwar pop singers do not belong. 59

\footnotetext{
${ }^{58}$ Crooning is so often discussed in terms of male singers, that to apply to female singers creates more problems than it solves. In his chapter on male crooners of the 1930s, Greenberg suggests that Anette Hanshaw sang most similarly to the male crooners of the era. See Jonathan Ross Greenberg, "Singing Up Close: Voice, Language, and Race in American Popular Music, 1925-1935," (PhD Dissertation, University of California, Los Angeles, 2008), 102, note 10.

${ }^{59}$ See Bateman, 39.
} 


\section{Doris Day: Workaround Technique, Safe Sexuality}

Doris Day is perhaps the only female postwar pop singer who is not in danger of being forgotten. But as much as her singing, it is her Hollywood legacy that ensures her remembrance today. Her highly successful film career and solo recording unfolded in parallel, making her a multi-media star like no other female performer of her era. Patti Page and the Les Paul/Mary Ford duo appeared on television but not with much longevity and certainly not with the impact that Day had in films.

Over the last decade in particular, Day has enjoyed a renewal of appreciation and respect for her career and influence. She is the subject of two thoroughly researched books that combine biography with thoughtful assessment of her works ${ }^{1}$, she is lauded as a top singer of her era by jazz critic Will Friedwald, ${ }^{2}$ and she was recently the subject of an album of song covers by critically acclaimed singer-songwriter Nellie MacKay. ${ }^{3}$

In a way, then, Day has come full circle since her reputation hit a low point in the late 1960s, a time when baby boom audiences found her films and image embarrassingly passé. Starting in the 1970s, Day has been gradually re-embraced as a valuable and entertaining figure in popular culture and even as a feminist-friendly icon. Further, as Day is experiencing a general renewal of goodwill and respect, she is also the subject of analysis and debate, within and beyond scholarly circles, relating to her presentation of gender and sexuality.

\footnotetext{
${ }^{1}$ David Kaufman, Doris Day: The Untold Story of the Girl Next Door (New York, NY: Virgin Books USA, 2008); Tom Santopietro, Considering Doris Day (New York: Thomas Dunne Books, 2007).

${ }^{2}$ Will Friedwald, "Doris Day," in A Biographical Guide to the Great Jazz and Pop Singers (New York: Pantheon Books, 2010).

${ }^{3}$ Nellie McKay, Normal as Blueberry Pie: A Tribute to Doris Day (New York: Verve: Universal Music Distribution, 2009).
} 
I include Day in this study not because she is a forgotten performer, but because her singing has received much less attention than her films. My work attends foremost to Day's singing career, singing style and vocal persona, with which I hope to enrich the conversation about Day's performances, her image, and her legacy across media. I concentrate on the early part of Day's career, from 1945 to 1956 . This period covers the tail end of her tenure as a big band singer with Les Brown's International Band of Renown, and the near entirety of her status as a solo recording artist with a significant presence on the pop singles charts. Further, this period corresponds approximately to the first half of Day's film career: from 1948-1954, Day was a contract actress with Warner Brothers, and made 17 films for the studio. These films were primarily light-hearted musicals in which Day played bubbly ingénues. This period does not include the "sex comedies" for which Day is perhaps best known today (including Pillow Talk and Lover Come Back with Rock Hudson.) I am particularly interested in the early Warner's films, for two reasons. First, because these films coincide with Day's status as a top-charting pop singer and I seek connections between her vocal persona and concurrent film image; and, second, because sometimes the Warner's films are counterpoised with Day's subsequent films in order to contrast a more "sexual" latter-day Day with a more "girlish" or "virginal" Day. While there are certainly many differences between Day's earlier and later films, I find it much more helpful to view Day's presentation of gender and sexuality as evolving over her career, rather than subject to dramatic ruptures.

Day's singing does not demonstrate the same robust technique enjoyed by some of her peers, but she offers a different set of vocal sounds and capabilities as a singer. In 
this chapter, I listen closely to her singing style, and show how she hones a technique that that does not rely on traditional qualities of "good singing" but instead allows her to use qualities of "acting," controlling sung lines as if they were speech

I then bring Day's vocal personae into dialogue with a more general reception and discussion of her images of gender and sexuality in film, and I relate these to postwar norms and expectations. I argue that, despite some protests to the contrary, Doris Day was never not a sex symbol. She projected what I call "safe sexuality," an articulation of desire and desirability especially suited to her time. The postwar era saw a decades-old trend toward sexual liberalism countered by a new (re-)investment in domestic values and traditional gender roles. While this new traditionalism did not quash Americans' increasing tolerance, even interest, in sexually suggestive materials, it invited a careful funneling and projection of sexual desire and sexual expression into forms that were simultaneously compatible with the new norms and ideals

\section{Doris Day, singer}

Day's recording career started when she took part in the making of some fortytwo records as a singer with the Les Brown band between 1940 and 1946. ${ }^{4}$ Twelve of these went on to become Top 20 hits, including "Sentimental Journey" and "My Dreams Are Getting Better All the Time," which hit number one.

When Day left the Brown band in 1947, she was offered a solo deal with Columbia Records (the same label that hosted Les Brown's ensemble.) Her first recordings as a soloist were made in New York in February 1947, though the resulting

\footnotetext{
${ }^{4}$ Santopietro, Considering Doris Day, 186.
} 
records, "It Takes Time," "My Young and Foolish Heart," "Tell Me, Dream Face," and "Pete" did not chart. Her first charting hit as a "soloist" was not a solo record, but a duet with Buddy Clark, a postwar pop singer with whom she would record a total of eleven records. ${ }^{5}$ Day's first hit as a soloist was "It's Magic" from her film debut Romance on the High Seas.

The Les Brown records feature Day in the role of "girl singer"- this was the affectionately dismissive term for women big band vocalists. The musical style and form on these records is standard for late swing era big band vocal pieces: the band introduces the tune, playing the chorus once through, then the vocalist enters for one or one and a half iterations of the chorus. Brown's band played mostly newly written pop songs and performed most of them as "rhythm" numbers - that is, in arrangements with an emphatic groove. The ensemble also recorded "sweet" numbers - ballads that prioritize melody above groove and that allow for significant melodic push and pull within the rhythmic framework (i.e. rubato.)

As a soloist, Day recorded singles that ranged in style as per the rules of the pop recordings of the era. Columbia was responsible for selecting songs, preparing arrangements and organizing recording sessions. Mitch Miller became Columbia’s “A\&R man" (the staff person charged with finding artists and assigning them appropriate repertoire) in 1950 and would be in charge of Day's recordings for the next ten years. ${ }^{6}$

Postwar pop singers had some choice in song selection, but this varied between singers and across individual singers' careers. A typical recording output for a singer of

\footnotetext{
${ }^{5}$ Ibid., 193.

${ }^{6}$ Kaufman, Doris Day, 106.
} 
this era would be comprised of some songs they loved and loved to perform, a handful they didn't care for, and many more they found decent and attempted to make the most of. In her autobiography, Day describes how she instantly loved the songs "Sentimental Journey" and "Secret Love," and that, in contrast, she was initially unimpressed with "Whatever Will Be (Que Sera Sera)." Mitch Miller recalls that Day did not want to record "A Guy is a Guy." Evidently Miller insisted that she record it, showing both that he could be dictatorial at times, and that he was good at gauging the music market, because Day’s “Guy” became a number one hit. ${ }^{8}$

The singles that Day recorded with Les Brown and then as a soloist can be grouped into the following substyles: sweet ballads, rhythm numbers (ballads, moderate or uptempo) Latin, country or novelty. (See figure 1.1 and table 1.1.) Day had seventy-six singles on the Billboard charts, including 21 that entered the top ten, and seven that reached number one. ${ }^{9}$ (See tables 2.1 and 2.2.)

Day is also one of the first pop singers to succeed in the then-novel album format. In the earlier years, Day's albums were soundtracks accompanying her films. ${ }^{10}$ Then, starting with Day by Day, she produced concept albums not attached to any film. (See table 2.3.) While these albums tend to be favored critically above the singles, this chapter focuses on the singles because of the greater audience reach and ubiquity they had.

\footnotetext{
${ }^{7}$ A. E. Hotchner, Doris Day: Her Own Story (New York: William Morrow, 1975), 159.

${ }^{8}$ Kaufman, Doris Day, 107.

${ }^{9}$ Santopietro, Considering Doris Day, 191. The seven hits are: "Sentimental Journey," "My Dreams are Getting Better all the Time," "Love Somebody," "Bewitched," "A Guy is a Guy," "If I Give My Heart to You" and "Secret Love."

${ }^{10}$ Santopietro, Considering Doris Day, 199. Technically, these were not soundtracks because the music was re-recorded, with subtle changes, for the albums owing to an agreement between Warner's and Columbia Records. Warner's owned the rights to Day's vocal performances on film, so Columbia had Day re-record the songs she sang in the films and released the results on Columbia LPs carrying the film's title in large type.
} 
TABLE 2.1 Hit songs recorded by Les Brown featuring Doris Day

\begin{tabular}{|l|l|l|r|}
\hline \multicolumn{1}{|c|}{ Year } & \multicolumn{1}{|c|}{ Song } & \multicolumn{1}{c|}{ Style } & \multicolumn{1}{c|}{$\begin{array}{c}\text { Top chart } \\
\text { position }\end{array}$} \\
\hline 1945 & Sentimental Journey & Rhythm ballad & 1 \\
\hline 1945 & My Dreams Are Getting Better All the Time & Rhythm ballad & 1 \\
\hline 1945 & Tain't Me & $\begin{array}{l}\text { Rhythm } \\
\text { moderate }\end{array}$ & 10 \\
\hline 1945 & Till The End of Time & Sweet ballad & 3 \\
\hline 1946 & You Won't Be Satisfied (Until You Break My Heart) & Rhythm ballad & 2 \\
\hline 1946 & I Got the Sun In The Morning & Rhythm uptempo & 10 \\
\hline 1946 & The Whole World Is Singing My Song & Sweet ballad & 6 \\
\hline 1946 & Sooner or Later & Rhythm ballad & 8 \\
\hline
\end{tabular}

Source: Whitburn 2002. (Style attributions mine.)

TABLE 2.2 Doris Day's hit singles as soloist

\begin{tabular}{|c|c|c|c|}
\hline Year & Song & Style & $\begin{array}{l}\text { Top chart } \\
\text { position }\end{array}$ \\
\hline 1948 & Love Somebody & Rhythm moderate & 1 \\
\hline 1948 & Confess & Rhythm ballad & 16 \\
\hline 1948 & It's Magic & Sweet ballad & 2 \\
\hline 1948 & My Darling My Darling/That Certain Party & Sweet ballad & 7 \\
\hline 1949 & Powder Your Face With Sunshine (Smile! Smile! Smile!) & Rhythm uptempo & 16 \\
\hline 1949 & Again & Rhythm ballad & 2 \\
\hline 1949 & Everywhere You Go & Rhythm moderate & 22 \\
\hline 1949 & Let's Take an Old-Fashioned Walk & Rhythm moderate & 17 \\
\hline 1949 & (Where Are You) Now That I Need You & Rhythm moderate & 20 \\
\hline 1949 & Canadian Capers (Cuttin' Capers) & Rhythm uptempo & 15 \\
\hline 1949 & There's A Bluebird On Your Windowsill & Rhythm uptempo & 19 \\
\hline 1950 & Quicksilver & Country uptempo & 20 \\
\hline 1950 & Enjoy Yourself (It's Later Than You Think) & Latin & 24 \\
\hline 1950 & I Said My Pajamas (And Put On My Pray'rs) & Novelty & 21 \\
\hline 1950 & Hoop-Dee-Doo & Novelty & 17 \\
\hline 1950 & Bewitched & Sweet ballad & 9 \\
\hline 1950 & I Didn't Slip - I Wasn't Pushed - I Fell & Novelty & 19 \\
\hline 1950 & A Bushel And A Peck & Novelty & 16 \\
\hline 1951 & Would I Love You (Love You, Love You) & Latin & 10 \\
\hline 1951 & (Why Did I Tell You I Was Going To) Shanghai & Rhythm uptempo & 7 \\
\hline 1951 & Domino & Sweet ballad & 21 \\
\hline 1952 & A Guy Is A Guy & Rhythm moderate & 1 \\
\hline 1952 & Sugar Bush & Novelty & 7 \\
\hline 1952 & When I Fall In Love & Sweet ballad & 20 \\
\hline 1952 & No Two People & Rhythm moderate & 25 \\
\hline 1952 & A Full Time Job & Country uptempo & 20 \\
\hline 1953 & Mister Tap Toe & Novelty & 10 \\
\hline
\end{tabular}




\begin{tabular}{|r|l|l|r|}
\hline Year & \multicolumn{1}{|c|}{ Song } & \multicolumn{1}{c|}{ Style } & \multicolumn{1}{c|}{$\begin{array}{c}\text { Top chart } \\
\text { position }\end{array}$} \\
\hline 1953 & Candy Lips & Rhythm uptempo & 17 \\
\hline 1953 & Choo Choo Train (Ch-Ch-Foo) & Novelty & 20 \\
\hline 1954 & Secret Love & Sweet ballad & 1 \\
\hline 1954 & I Speak to The Stars & Sweet ballad & 16 \\
\hline 1954 & If I Give My Heart To You & Rhythm ballad & 3 \\
\hline 1956 & Que Sera Sera & Novelty & 2 \\
\hline 1958 & Everybody Loves a Lover & Novelty & 6 \\
\hline
\end{tabular}

Sources: Whitburn 2001, Whitburn 2002.

TABLE 2.3 Doris Day's albums released 1949-1957

\begin{tabular}{|r|l|r|}
\hline \multicolumn{1}{|c|}{ Year } & \multicolumn{1}{|c|}{ Album title } & Top chart position \\
\hline 1949 & You're My Thrill & 5 \\
\hline 1950 & Young Man With A Horn Young Man With A Horn & 1 \\
\hline 1950 & Tea For Two & 3 \\
\hline 1951 & Lullaby Of Broadway & 1 \\
\hline 1951 & On Moonlight Bay & 2 \\
\hline 1952 & l'll See You In My Dreams & 1 \\
\hline 1953 & By The Light of the Silvery Moon & 3 \\
\hline 1953 & Calamity Jane & 2 \\
\hline 1954 & Young At Heart & 15 \\
\hline 1955 & Love Me Or Leave Me & 1 \\
\hline 1956 & Day By Day & 11 \\
\hline 1957 & The Pajama Game: Original Soundtrack Recording & 9 \\
\hline
\end{tabular}

Source: Whitburn 2001, Whitburn 2002.

\section{Singing the Raine way}

Day's unusual vocal style is connected to her unusual path into professional

singing. She did not start singing as a child, nor did she sing at family gatherings or for a variety of audiences and settings. These kinds of childhood amateur and semiprofessional introductions to singing are what build many singers' voices, giving them power (loudness) and breath control, as well as a sense of ease in front of an audience in large performance spaces. Though many professional singers of Day's era ended up doing much of their singing in recording studios, most combined, and enjoyed combining, live shows with recording sessions. This would not be Day's experience: she 
started to sing seriously only in her mid teens. She spent two one-year stints with Les Brown between 1940 and 1946, and then she retreated completely from live singing after 1947.

Day undertook singing under the tutelage of Grace Raine, a Cincinnati vocal coach who specialized in radio singing. Given the fact that Day came to singing relatively late, it is not that surprising that she at first failed to impress Raine. In fact the teacher initially refused to take Day on, telling Day's mother: "It would be a waste of both my time and yours for Doris to take singing lessons. Frankly, and please don't think me unkind, Doris just hasn’t any talent." "Raine told Day biographer Kaufman, "I had heard her sing a few times on the radio...and she just didn't have it...but a song plugger told me that she was so beautiful that it didn't matter whether or not she could even carry a tune."12

Raine may have been initially reluctant, but when she took Day on, she taught her lessons that would stay with the singer for the rest of her career. ${ }^{13}$ Raine taught Day a careful and intimate style of microphone singing suited to radio, and she encouraged Day to imagine she was singing to one person. For two years, Raine would see Day twice a week for half hour lessons, and as part of their routine, Day would sing into a recording device that they could play back. ${ }^{14}$

Raine taught Day to invest meaning and feeling into lyrics and songs as if they

${ }^{11}$ Kaufman, Doris Day, 19.

${ }^{12}$ Ibid.

${ }^{13}$ A. E. Hotchner, Doris Day: Her Own Story (New York: William Morrow, 1975), 40.

${ }^{14}$ Kaufman, Doris Day, 19-20. Kaufman does not provide any information about the nature of this playback device, but the detail is interesting because it shows that both teacher and student were interested in the recorded "result" of the singing voice as heard through playback, as much as or more than during the instance of live singing. 
were monologues from a play. As Day recalls, "Grace [Raine] taught me the importance of singing the lyrics correctly... 'When you sing the words to this song,' she'd say, in that sweet, gentle way of hers, 'imagine that you're singing to one person, just one, a very special person, and that you're singing it in that someone's ear.",15 Day makes the connection between these instructions and her acting career: "I worked very hard on projecting lyrics, feeling them, putting them within the framework of some imagined scene that fitted the song. It was this early work on lyrics, I'm convinced, that later helped me make the transition from band singing to movie acting."

In terms of the more technical aspects of singing, Raine emphasized low and moderate volume singing. She gave Day the standard tips about avoiding distortion with consonants (how to avoid popping $p$ 's and how to make $s$ 's cleaner ${ }^{17}$ ) but she seems to have gone further than that in conveying to Day that microphone singing should be smooth, controlled, and free of any vocal "noise" not due to singing itself. Day remembers Raine saying, "Don't crowd the microphone...You're working too hard. Remember, an audience might not hear you gasp for air, but a microphone does." ${ }^{18}$ Furthermore, Raine discouraged Day from “belting," as Day recalled the following instructions: “Don't just belt out a song, because that's impersonal, just putting it up for grabs."19

Raine seems not to have worked on bolstering Day's basic vocal tone-neither she nor Day discusses technical exercises to improve on vocal power, efficiency or range.

\footnotetext{
${ }^{15}$ Hotchner, Doris Day: Her Own Story, 39.

${ }^{16}$ Ibid.

${ }^{17}$ Ibid., 40.

${ }^{18}$ Ibid.

${ }^{19}$ Ibid., 39.
} 
In fact, instructions as recalled by Day suggest that for Raine, pursuit of excellent vocal tone was not a priority: "How many times have you heard marvelous singers with beautiful tone quality whose song means nothing to you because it doesn't mean anything to them?"20

What these comments from Raine and Day tell us is that Day learned from the beginning to focus on low and moderate-volume singing as opposed to belting; she learned to emphasize a controlled way of singing (which may have inhibited the development of relaxation in the vocal apparatus that characterizes many successful singers); and that Raine did not emphasize improving Day's baseline vocal tone, and instead decided that they should focus more on interpretation. Above all else, Day learned from Raine how to use the microphone to her advantage and how to communicate feeling.

Day's reflection on her own voice reveals an acknowledgment of her limits and an understanding of her strengths. She never critiques her own voice outright, but roundabout statements imply that she is aware of her technical limits:

Grace Raine really taught me virtually everything I ever learned about singing. Of course, no one can teach you to sing-either you are naturally endowed or you are not— but you can be taught how to make the most of whatever your natural talent is. ${ }^{21}$

Perhaps Day is acknowledging here that she may not have been "naturally endowed" with the technical abilities of some of her singing peers, but that she did have a gift for

\footnotetext{
${ }^{20}$ Hotchner, Doris Day: Her Own Story, 39.

${ }^{21}$ Ibid.
} 
communication and expression through song; a gift that Raine appreciated and nurtured.

In a 1968 interview with the New York Times, Day compares herself to Barbra Streisand whose star is rising during a time when Day's is fading. Day says, "Streisand is great with the big orchestra. She can really belt. I'm not like that. I like the simplest form of music. I would prefer singing with just a guitar or piano. See, I have to sing in somebody's ear."22

As mentioned, Day stopped performing live after 1947. She does not state an explanation for this outright in her autobiography, but we can intuit her motives by reading about her enjoyment of studio recording, which she did for both films and records:

I enjoyed singing for films because it wasn't the impromptu business of standing in front of a ballroom band or a radio audience and hoping that one shot, despite all its distractions, would approximate my best effort. Although a movie song is filmed on the set during its performance, the song itself is prerecorded in a recording studio under ideal conditions before the picture ever starts. In the solitude of a room with perfect acoustics, I could record a song as many times as necessary to get it right. .... Later on in my career, I often recorded without an orchestra. This was achieved by having the orchestra put its accompaniment on a track; then, alone in the studio, by means of a headset, I would sing to that prerecorded accompaniment. I like that method for films and albums best of all

\footnotetext{
${ }^{22}$ Santopietro, Considering Doris Day, 194 (italics in original).
} 
because of the flexibility it gives me in allowing me to record on a day of my choosing, when I know my voice is in good shape. ${ }^{23}$

This comment suggests that Day did not feel she could do her best singing unless she had a lot of control over the performance situation — a studio, Day says, offers fewer "distractions" than a live radio performance or a big live venue. But Day's comment could also reveal a concern about reliability — the worry that listeners would not hear in a live performance the quality they were accustomed to on her records.

Interestingly, immediately after this commentary, Day presents an opposing position on singing, emphasizing the importance of "liveness," interaction and spontaneity. First, she notes, "But every artist, including me, does her best work when she can feel the band's presence. ${ }^{24}$ And then she recounts an instance during her career when she requested to sing "live" on the film set instead of lip-synching to a pre-recorded performance. Her reasoning? The acting required it: "In 1957, in Pajama Game, I had to sing 'Hey There' while crying, and in a manner that was so involved with the action." 25 Day insisted on singing while carrying out the scene so that her singing performance would merge with rather than stand apart from her acting performance. Day may have included this anecdote in her autobiography to disabuse readers of the idea that she is so committed to the process of studio recording, and multiple takes to get perfection, that there could not be any "real" expressiveness in her recordings. Her comments about "being involved" serve to inform readers that Day is committed to the communication of emotion through song, and not, as it may sound like from the previous excerpt, the

\footnotetext{
${ }^{23}$ Hotchner, Doris Day: Her Own Story, 113-4.

${ }^{24}$ Ibid., 114.

${ }^{25}$ Ibid.
} 
vanity-driven goal of sounding as good as possible.

Day's autobiographical reflections on singing suggest that she is aware of her technical limits, especially when it comes to singing loudly, singing live, or singing in high pressure situations. Day also makes clear that she knows her strength is to convey intimacy through recording. Her comments further suggest that she has found a way around her technical limits, and that she is most comfortable singing in a studio with good acoustics and with the opportunity to do multiple takes.

\section{What postwar listeners heard}

The historical reception surrounding Day's singing centers on at least four major themes: there are descriptors of her voice as sexy or sultry; and related descriptors of its intimate and expressive qualities. (See table 1.5.) Regarding her uptempo numbers, comments about her energy predominate. There is also a strain of commentary that either hints at or outright states that Day's voice as a technical instrument is not particularly powerful or striking.

Day's reputation as a singer with a sultry, sexy voice and style of delivery was established as early as 1945 with the release of "Sentimental Journey." Billboard writes that Day is "displaying the required sultry qualities in her pipes for the chanting."26 Commenting on her solo songs, "Chocolate Sundae on a Saturday Night" and "Just an Old Love of Mine," Billboard suggests that the tunes are "made for her....sultry feeling." ${ }^{27}$ Upon the release of Day's first album, You're My Thrill (1949), Billboard notes, "There have been few singers who have been able to transfer a sexy sound to wax

\footnotetext{
${ }^{26}$ Billboard, March 3, 1945.

${ }^{27}$ Billboard, September 27, 1947, 118.
} 
quite as pleasingly as does Doris." 28 A Los Angeles Times writer calls Day's a “comehither voice.” ${ }^{, 29}$ Some specificity on what a sexy voice entails (what makes a voice sexy exactly?) comes in comments that connect sexiness to a throaty or husky sound: for example, the same reviewer of You're My Thrill cited above notes that Day has a "throaty style." 30 And in a review of the song "Let it Ring," Billboard says, "La Day [sic] just caresses the sounds here to some of her huskiest, sexiest singing in the book."31

A related quality often noted in Day's singing is intimacy. Billboard writes that "Doris achieves a high degree of intimacy that counts so much for her chanting," she sings with a "soft and intimate feeling," 33 and that she has "her own intimate" style. ${ }^{34}$ Chicago Tribune columnist Fred Reynolds is more explicit in his assessment of this quality, noting that that Day sings with a "me-to-you intimate touch.",35

A third thematic category in Day's vocal reception is "expressiveness." While it might seem odd to single out a quality that is usually considered a standard component of musical performance (aren't all singers “expressive?"), it is worthwhile considering what Billboard writers mean when they use this term. Billboard describes the song "It's Magic" as showing "true, expressive chirping,"36 and her performance on the album Young Man with a Horn "warm, expressive and tasteful." ${ }^{37}$ Billboard uses "expressive"

${ }^{28}$ Billboard, September 17, 1949, 36.

${ }^{29}$ John L. Scott, "It's Magic How Doris Day Sings Way to Film Peaks," Los Angeles Times, February 27, 1949.

${ }^{30}$ Billboard, September 17, 1949, 36.

${ }^{31}$ Billboard, December 10, 1955, 30.

${ }^{32}$ Billboard, July 12, 1947, 118.

${ }^{33}$ Billboard, September 27, 1947,118.

${ }^{34}$ Billboard, September 17, 1949, 36.

${ }^{35}$ Fred Reynolds, "Platter Chatter," Chicago Tribune, March 3, 1952.

${ }^{36}$ Billboard, April 24, 1948.

${ }^{37}$ Billboard, April 8, 1950. 
along with a related nexus of terms_-including "tender" and "moving"_-for ballads in which Day seems to be communicating directly to listeners. Day's interpretation of "Secret Love" is deemed "moving," 38 and the review of By the Light of the Silvery Moon praises Day for her singing of ballads with "fetching tenderness." 39 Reynolds of the Chicago Tribune says that Day sings "with the refreshing warmth of a spring breeze" and in a different piece, summarizes her appeal in this way: "Who is so rare as Doris Day? Whenever she sings, something especially nice happens."41

The above review excerpts, then, show that Day's ballad performances were notable to reviewers for being sexy/sultry, for conveying intimacy, and for expressivity. These kinds of descriptors suggest that listeners heard Day the singer very much as a woman with a body and a personality rather than simply a disembodied voice. Her performances may have compelled listeners to envision her bodily presence, to imagine her sexuality or to be conscious of their own, and to conceive of "Day the singer" as more than "merely a singer," but rather as a "real person" who exuded emotions and characteristics that were really "hers."

The uptempo songs in Day's repertoire, and her performance in these songs, contrast dramatically from the slower numbers, and so it is not surprising that these faster songs invite different assessments. Chiefly, such assessments hinge on Day’s palpable energy. For example, in a review of the By the Light of the Silvery Moon soundtrack album, Billboard notes that Day demonstrates "exuberance and brightness on uptempo

\footnotetext{
${ }^{38}$ Billboard, November 7, 1953, 36.

${ }^{39}$ Billboard, April 18, 1953, 42.

${ }^{40}$ Reynolds, "Platter Chatter," March 3, 1952.

${ }^{41}$ Reynolds, "Platter Chatter," April 20, 1953.
} 
tunes." 42 Day is called a "pert songstress,"43 an "engaging young singer and young comedienne" 44 and columnist Eddie Gallaher praises her "winsome personality". ${ }^{45}$ In a subsequent piece, discussing Day’s “Hoop-Dee-Doo,” Gallaher calls Day “as pert and winning as ever."46

Viewed a whole, the above excerpts by newspaper and Billboard reviewers tend to focus on emotions and impressions imparted by Day's singing rather than vocaltechnical proficiency. While Day receives mostly positive assessments, there are a handful of reviews, especially earlier in her career, that suggest commentators notice technical shortcomings in her singing. For example, a Billboard review of a live show notes that Day's voice could not be heard over the Les Brown Band. In a review of the record "My Young and Foolish Heart," Billboard notes that Day shows "hardly enough individuality and substance in her singing" to make the song a success. ${ }^{47}$ By the same publication, Day is deemed to sing with "forced restraint" in the song "Sooner or Later."48

Likewise, the New York Times was critical of Day in her early years as a performer, and in a review of her performance in Romance on the High Seas, the paper calls her singing voice "adequate," and "nothing to herald." ${ }^{, 49}$ By 1955, the New York Times had come around to appreciate Day as a performer, and ran a full profile of her.

${ }^{42}$ Billboard, April 18, 1953, 42.

${ }^{43}$ John L. Scott, Review of Romance on the High Seas, Los Angeles Times, June 26, 1948.

${ }^{44}$ Orval Hopkins, "Doris Day Makes Nice Start in Musical Film at Warner," Washington Post, July 2, 1948.

${ }^{45}$ Eddie Gallaher, “On Records,” Washington Post, November 27, 1949.

${ }^{46}$ Gallaher, "On Records,” June 4, 1950.

${ }^{47}$ Billboard, July 12, 1947, 118.

${ }^{48}$ Billboard, December 21, 1946.

${ }^{49}$ Bosley Crowther, Review of Romance on the High Seas, New York Times, June 26, 1948. 
But even at this later stage, the Times' evaluation of Day's voice is at best measured, and at worst a backhanded compliment: the Times writer suggests that Day is "a good example of how a nice, unstartling voice can be parlayed into a million-dollar film property.",50

Viewed as a whole, Day's historical reception suggests that writers were not unaware of some technical shortcomings in her singing voice, but that overall these did not detract from Day's appeal as a vocalist. This appeal was chiefly created through Day's ability to project dimensions of sexuality and intimacy in ballads and energy in her uptempo numbers. More broadly, her recorded performances appear to invite listeners to imagine her as a real person expressing "herself" and thus letting her listeners "know" her and the experiences and emotions she sang about.

\section{Day’s "workaround" technique}

An understanding of Day's vocal training and her professed approach to singing informs a consideration of her vocal technique. While it is difficult to describe "general" attributes of Day's voice, since her timbre varies a great deal between and sometimes within songs, we can say that when she is neither singing at low-volume low-pitch, nor belting at higher pitches, that her "baseline" vocal quality is thinner rather than richer. The pitch compass of her hit songs is on average a tone higher than Patti Page's and two to three tones higher than Mary Ford's, suggesting that Day has a naturally higher range than her peers. Most of Day's most popular singles unfold in keys and arrangements that allow her to sing a B4 in a climactic point in a song, whereas for Patti Page, this high

\footnotetext{
${ }^{50}$ Howard Thompson, New York Times, April 24, 1955.
} 
point is often lower (A4) and for Mary Ford, lower still (G4.) (See table 4.4 in Mary Ford chapter.)

An important feature across Day's singing has to do with her very "mouthy" diction. Linguists have suggested that we can often "hear" facial expression in the absence of visual-facial cues, and Day often pronounces song lyrics in ways that audibly suggest either a smiling or a puckered mouth shape. ${ }^{51}$ This departs from more standard singing techniques whereby singers prioritize sound quality, which in turn demands “singing” mouth shapes, which do not necessarily match up to a singer's repertoire of non-singing facial expressions. Although it is not possible to confirm what Day's face looked liked in recording sessions, what is important is that the sounds she makes are compatible with specific facial expressions, which in turn makes it easier to imagine her face as she sings.

Several features of Day's technique are specific to her ballad singing. The first is her use of a breathy tone on low pitches. Although breathy sounds can convey relaxation to a listener - the singer is not energetically "singing out" but moderating their volumethey are in fact the product of tension in the voice mechanism. ${ }^{52}$ Breathy tones include non-tonal "noise" that interferes with the production of tone. Yet many singers' use of breathy tone is experienced positively, and in Day's case, it is likely breathiness that constitutes at least some of the "husky" and "sultry" qualities that her reviewers praise.

\footnotetext{
${ }^{51}$ Amy Drahota, Alan Costall, and Vasudevi Reddy, "The Vocal Communication of Different Kinds of Smile," Speech Communication 50 (2008): 278-287. I became aware of this article thanks to an interview with Amy Drahota on NPR radio: "Hearing a Smile in Tone of Voice: NPR," NPR.org, accessed May 6, 2012, http://www.npr.org/templates/story/story.php?storyId=1825513.

${ }^{52}$ Laura Anne Bateman, "Soprano, Style and Voice Quality: Acoustic and Laryngographic Correlates" (Master of Arts Thesis, University of Victoria, 2003), 101. In her experiments, Bateman observed that "breathy voice" and "whispery voice" were most often accompanied by a constriction of the singer's larynx.
} 
Another feature of Day's workaround technique has to do with her vibrato. As discussed in Chapter 1, voice scientists and pedagogues generally agree that the phenomenon of vibrato as it occurs in classical singing is an involuntary, yet desirable, consequence of relaxed voice production. However, pedagogues also talk about different kinds of vibrato besides this "natural" one: outside of classical music, singers are free to sing with whatever kind of vibrato they can or wish to produce; or they can opt to avoid vibrato altogether. While many popular singers do exhibit a "natural" (involuntary but desirable) vibrato, others may induce vibrato through voluntary manipulation of the diaphragm or throat.

There are several indications that in low to moderate dynamic singing, Day's vibrato is more throat-induced than natural. It sounds more rapid, (more "fluttery") and more intensity-based than a natural vibrato. It would certainly make sense that Day recruits this voluntary, throat-controlled vibrato, because the other qualities I have mentioned so far - the "mouthy" diction choices, and the breathy tone — can all induce a tension to the vocal mechanism that would itself be a deterrent for the development of a natural vibrato.

There are several ways Day's induced vibrato might play a role in her technique and thereby affect impressions of her singing. First, her induced vibrato might enhance the perception of breathy tone: if Day's tone quality is already breathy, then a vibratocaused variation in intensity could further bring attention to the "airflow" dimension of singing. Another possibility is that Day's fluttery vibrato may convey fragility and vulnerability - this may be in part what listeners experience in her "tender" songs. 
One particular manifestation of her vibrato occurs more frequently in her Les Brown recordings when she gives what I call an "attack-pullback" articulation of certain notes. In these instances, Day strikes a pitch in straight tone, and then initiates her vibrato while simultaneously lowering the dynamics. In songs whose lyrics convey a flirtatious mode of address, this attack-pullback can suggest vocal coyness, as if Day is offering her voice and then withholding. In more tender songs, the attack-pullback might instead convey inner joy, or a kind of happiness that does not need to be loudly and publicly proclaimed but can be cherished privately.

Another facet of Day's “workaround" technique involves her abilities with respect to register blending. Day is like other female postwar pop singers in that she makes some limited use of chest voice belt tone within the context of relaxed singing. However, unlike many postwar singers who are able to bridge their chest voice and low head voice and are able to move up and down pitch range in ways that disguise the register break, Day seems unable to take her chest voice down below belt range. So, while she has the capacity to project a bright, belted tone for pitches in the G4-B4 range, she does not have a way of bringing the fullnedss of chest voice down in pitch. Her singing in the pitches below G4 reverts to a thinner or breathier quality, suggesting that she has switched to low head register. Day's workaround solution to this would-be problem is simply to abandon the "seamless" register aesthetic and instead sing in a way that lays bare the abrupt register change. Especially when used in cheerful or humorous songs, this approach exudes an unfussy and practical attitude. This technique can be so effectively expressive and suggest such vocal confidence that it may not occur to listeners to consider the 
singer's technical limits.

Although Day started with a deficit in terms of training and live singing experience, as a recording artist, she found what worked for her and her singing public. In fact, her workaround approach may be responsible for her popularity: it allowed her to focus more on singing as acting and singing as speech; and it allowed her to project strikingly contrasting personae between songs.

The "sexy/sultry" persona comes across in much of Day's early work with Les Brown. Characteristics of this persona are the low volume, breathy tone and the attackpullback approach to articulation, dynamics, and vibrato. Taken together, these build a persona that projects coyness and intimacy. The most notable diction feature of this persona is the "pucker mouth" pronunciation. The "tender" persona is in evidence for love ballads like "It's Magic" and "Secret Love." It is in these songs that she is likely to "sing with a smile," and to "caress sound." Day's "sunny" persona takes the floor for uptempo numbers. In these songs she does not prioritize beautiful tone. Instead, she hits the right pitches with energy and rhythmic drive. This persona is unfussy about jarring register changes — she uses "whatever timbre is at hand" in order to efficiently "get the job done." These songs project a persona who is cheerful and practical rather than precious or affected.

\section{Sexy/sultry in "Sentimental Journey"}

The song that first brought Doris Day to national attention was her biggest Les Brown single, "Sentimental Journey," recorded in November 1944 and released in March 1945. Fantastically popular with the public, the song reached number one on the 
Billboard chart and spent a total of twenty-three weeks there overall.

A rhythm ballad written by Buddy Green and Les Brown, the song is in 32-bar AABA chorus form. On the recording, the chorus is articulated once through instrumentally in F major, but cut short before the final A section. After a four measure instrumental transition to A major, Day enters on vocals, and sings an entire chorus.

This song provides a good example of Day's sexy/sultry persona. Day creates this persona with several techniques discussed above. First, she uses a breathy tone in her lower range and it is especially notable here because of the contrast with the bright timbres and lush harmonies of the instrumental chorus that introduces her. To her breathy tone, Day applies her "attack-pullback" mode of articulation so that she strikes notes of longer duration with a gentle accentuation, and then pulls back in dynamics and applies her vibrato.

A second technique Day uses comes in the third line of the second A section: she pronounces the words "wild anticipation" with what sounds like a pucker-face, which comes as a notable contrast from her diction up to this point — characterized by a mild southern accent. ${ }^{53}$ On the line "Like a child in wild anticipation," Day's pronunciation of "like" and "child" matches the earlier [a] sounds of the song. (See table 2.4) In sudden contrast, for the word "wild" Day speaks with a glided [æi] sound instead. Further, the "L" of "wild" receives exaggerated enunciation. The combination of these pronunciation factors makes it easy to imagine that Day has adopted pucker-face for this phrase, and

\footnotetext{
${ }^{53}$ In her autobiography, Day explains that growing up in Cincinnati, she acquired a "little southern drawl" that she was unaware of until she joined Les Brown's band. Brown pointed her accent out to her: "for instance, the way I sang "ah" for "I."” (Hotchner, Doris Day: Her Own Story, 56.) Day worked to modify her accent, and indeed, it seems to disappear completely by the time she starts her solo career.
} 
that for the next line, starting with the words, "long to hear," that she has moved back to the smile.

Day's techniques of breathy tone, attack-pullback and pucker-face help construct the sexy/sultry vocal persona. Elements of the arrangement help to bolster the salience of this persona. First, there is the way Day imitates the saxophones with their languorous upward swoop for the ascending third that forms the melodic building block of the A section. Day echoes the insinuating and suggestive gesture of the band with her voice. (See figure 2.1) But Day's effectiveness also depends on creating contrast with the band. The band presents rich multipart harmony, but then when Day comes in, her voice is dry and soft, and her tone measured, requiring the listener to focus in on her more private mode of expression.

Considered as a whole, this song treads a line between family-oriented longing for the comforts of home and a more sensual yearning for a romantic partner. Day's performance helps to keep the song hovering between the two registers. The phrase "sentimental journey" does not precisely indicate the nature of the feelings the speaker harbors as she anticipates her arrival home. The references to "home" may conjure the image of a return to one's hometown, which usually implies reunion with family and friends. But the song may also, or alternatively, imply reunion with a romantic/sexual partner. The fact that this song became anthemic for Americans on both sides of the Atlantic as World War II drew to an end does not resolve this ambiguity, because after the war, military personnel were of course variously reunited with lovers, family, and friends. The brash exuberance of the song's instrumental portion suggests public 
celebration and homecoming of a more family-oriented nature. Yet the melodic change from major to minor third in the fifth measure of each A section (see figure 2.1) might suggest a romantic/sexual side to the anticipated homecoming. This minor third might be heard as a "knowing wink" to the listener indicating that the "sentimental journey" in question is officially a domestic/family-oriented one, but that it has a romantic or sexual dimension. Day's "pucker face" on the words "wild anticipation" occurs during the minor-third unit of the melody, and more generally, her quiet and measured vocalizing creates a private and intimate sonic space bracketed by the larger, more "public" sonic space created by the exuberant band arrangement.

TABLE 2.4 Doris Day's pronunciation in "Sentimental Journey" (second A section)

\begin{tabular}{|l|l|}
\hline \multicolumn{1}{|c|}{ Lyric } & \multicolumn{1}{c|}{ Day's pronunciation } \\
\hline Got my bag, got my reservation & Got mah [æ] bag got mah [æ]... \\
\hline Spent each dime I could afford & ...each dahm [æ] ah [æ] could afford... \\
\hline Like a child in wild anticipation & Lahk [æ] a chahld [æ] in wi-ee-I-d [æi] anticipation... \\
\hline Long to hear that all aboard & Long to hear that all aboard \\
\hline
\end{tabular}

\section{FIGURE 2.1 Major-minor third alternation in "Sentimental Journey"}

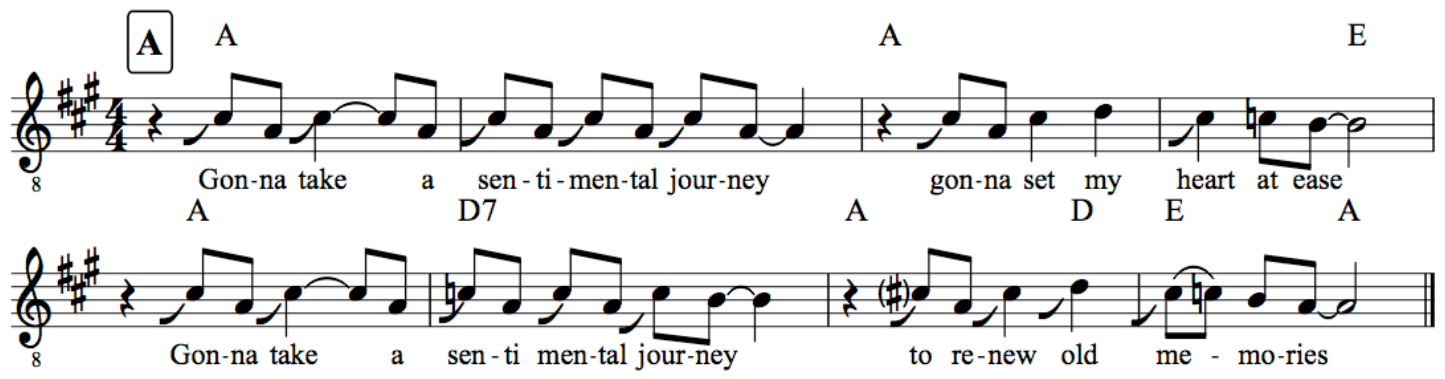




\section{Tender in "It's Magic"}

"It's Magic" was written by Sammy Kahn (lyrics) and Jules Styne (music) for Doris Day's first film, Romance on the High Seas. The single version, recorded in November 1947 under the direction of George Siravo and released in 1948, was Day's first solo record that sold over a million copies. ${ }^{54}$ Billboard deemed Day's singing on this record "true, expressive chirping"

"It's Magic" is a love song in which the speaker muses on the sense of enchantment she feels upon realizing that she is in love. The song is in 32-bar ABAC chorus form, and this recording presents one full iteration of the chorus, followed by a half chorus (AC only) during which the orchestra and Day perform call and response, after which Day resumes the full vocal part. Day's performance builds the tender vocal persona in several ways: her enunciation choices at several points suggest a "smile face," as if she is lovingly smiling at the listener. This expressive dimension is bolstered by her use of rubato, and fluttery vibrato.

The impression that Day is smiling through much of this song is conveyed by her pronunciation choices. She often chooses to lean on "smiley" vowels and consonants even when these go against more natural speech patterns. For example, she takes several opportunities to hum on the consonant " $n$ " (henceforth "nn-hum") by lingering on the final consonant of words ending in "n." So in the opening lines of the ballad, Day sings:

You sigh, the song beginnnnns,

You speak and I hear violinnnnnns

\footnotetext{
${ }^{54}$ Liner Notes, Doris Day Her Life in Music, 1940-1966. (London: Sony Music Entertainment, 2004).

${ }^{55}$ Billboard, April 24, 1948, 31.
} 
Sustaining an nn-hum is not standard in either classical or popular stage singing. In the classical tradition, singers avoid lingering on consonants and move to vowels as quickly as possible. Popular stage singers may lean on consonants in different ways than classical singers, yet they still need to dispense with the consonants quickly to land on vowels that allow for strong projection of pitch. Extensive use of nn-hum is only sustainable in intimate, well-miked performances or in recording sessions.

Day of course created "It's Magic" in a miked studio session, and thus the nnhum was a viable pronunciation choice. There are several reasons she may have chosen to emphasize this syllable throughout the song. From the singer's perspective, it creates a strong sense of resonance within the vocal tract thus providing sensory, internal feedback, and it allows for a gentle dynamic tapering of a phrase. ${ }^{56}$ The nn-hum can also be an attractive choice because it requires less breath than a sung vowel sound, making it a lowenergy choice for a singer who does not want to run out of breath. In Day's case, any of these reasons would be reason enough to linger on the nn-hum. But there is another possibility: the nn-hum mouth shape is compatible with a smile-shape. While we cannot know for sure whether Day smiled with each nn-hum while making this recording, these pronunciation choices allow for this possibility.

If the nn-hum allows a listener to imagine Day smiling, Day's use of rubato further facilitates this. When popular singers use rubato, they may choose to slow down and speed up in order to accentuate certain pitches or words that have strong affective potential or to better represent natural speech patterns. Yet Day's rubato choices seem to

\footnotetext{
${ }^{56}$ Emma Culpeper (professional vocalist), personal communication, March 15, 2013.
} 
follow a different logic: they allow her to linger on the "smiley" syllables. For example, her second line, "You speak and I hear violins," contains three "wide" vowel syllables that easily allow a smile-face: "speak," "hear" and "(vio)-lins." And these are exactly the syllables she leans on with rubato:

You speeeeeak and I heeeeeeear violinnnnns

This pattern of syllabic accentuation does not make the phrase more naturalistic to speech, nor does it provide any striking melodic or harmonic effects. The line is not very melodically active, most of it occurring on the tonic, so Day's specific rubato pattern does not provide unexpected color resulting from displacement of melodic pitch content over harmony. Thus this rubato pattern serves foremost to allow Day to linger on the smile-friendly vowels.

In addition to her use of smiley vowel choices, Day conveys tenderness with the combination of her breathy tone and fluttery vibrato. This is most notable every time she pronounces the word "magic." The first syllable is warmer and fuller, but the second syllable, "-gic" is consistently breathy and fluttery. This projects a sense that the speaker gets a bit "lost" in dreamy contentment every time she repeats that word.

Through her smiley pronunciation choices, breathy tone and fluttery vibrato, Day conveys breathless happiness about being in love. Listeners may find this presentation endearing, perhaps feeling privileged to experience the speaker's tender, private admissions. Some listeners may even experience Day's emotions with a bodily sympathy: the perceptible qualities of breathiness and smileyness may actually translate palpably to 
listeners so that they not only intuit Day's emotions, but they feel the physical correlates of these emotions.

\section{Tender (and bold) in "Secret Love"}

"Secret Love," Day's most famous ballad, is the musical highpoint of her film Calamity Jane. The song, written by Paul Francis Webber and Sammy Fain, was released as a single in 1953 to coincide with the movie's release. The song reached \#1 on Billboard, and it won Best Song at the Academy Awards for the same year.

This recording presents another articulation of Day's tender vocal persona, showcasing her use of breathy tone, fluttery vibrato, and smiley pronunciation choices. Particular to this ballad among Day's repertoire of ballads is the inclusion of a climactic note that is belted. This moment presents a bold departure from the lower-pitched and lower-dynamic singing to that point in the song.

As with "It's Magic," Day uses a breathy tone with fluttery vibrato on the lower notes in "Secret Love," and she emphasizes syllables compatible with a smiley face. For example, she holds the nn-hum in the opening line, "Onnnnnnnce I had a secret love." On the word "love," she makes a vowel adjustment that both allows for more resonance in the front of the mouth, and a smiley face-shape. Instead of singing "love" with a simple vowel sound (rhyming with "of" [lnkv]), she adds a diphthong to the word, effectively splitting it into two parts. "Love" becomes "luh-oave." Day deliberates through her twosyllable pronunciation of this word, conveying the image that she is caressing the word with her mouth, and ending its pronunciation with a smile.

What makes this ballad stand out among Day's ballads is its climactic belted note: 
the pitch B4 that begins the phrase, "Now I shout it from the highest hills." (See figure 2.2.) With this "money note," the tender vocal persona gives way to unbridled joy. First, it must be noted that the design of the melody, which spans an octave and a half, more or less demands that the peak pitch be belted, not least because this allows for a literal enactment of the lyrics, "now I shout it." But in Day's case, the performance ends up highlighting her lack of (or unwillingness to use) a lower-pitched chest voice. The sudden introduction of belt technique for "Now I shout it" is a dramatic change from the relaxed voice quality she has been presenting up to this point. (See figure 2.3.) The timbral contrast arising on "now I shout it" incorporates some of the technical "unfussiness" discussed above, in this case, conveying a bold forthrightness suggesting a speaker who is more concerned with cathartic release than with gradual timbral or registral transitions. Lastly, this belted note has the effect, both retroactively and moving forward, of conveying to the listener just how much sublimated joy bubbles under the surface during the tenderer points of the song.

FIGURE 2.2 Melodic excerpt showing climactic note in "Secret Love"

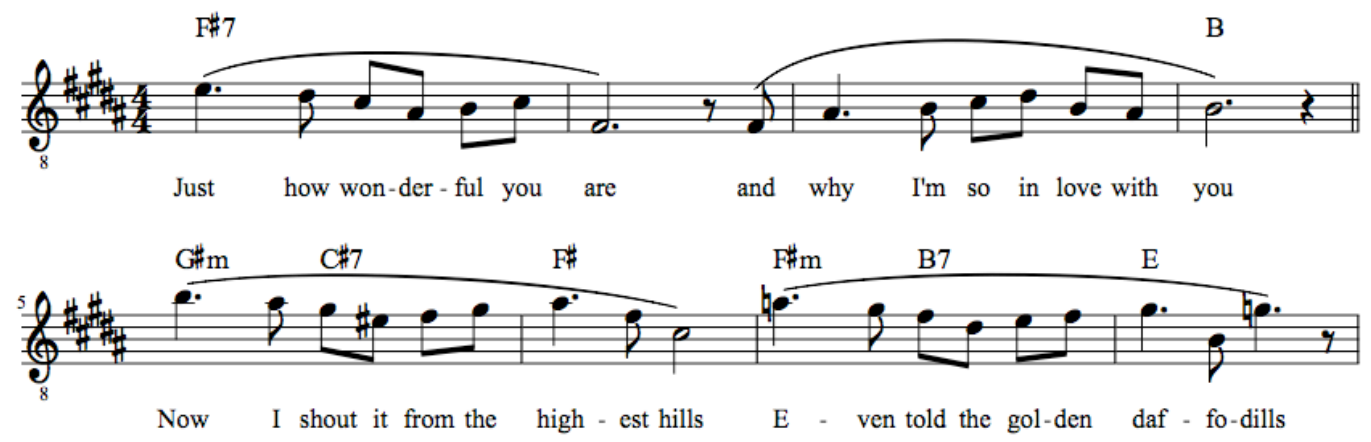




\section{FIGURE 2.3 Spectrogram view of Day's belted B4 on lyric "Now" in "Secret Love"}

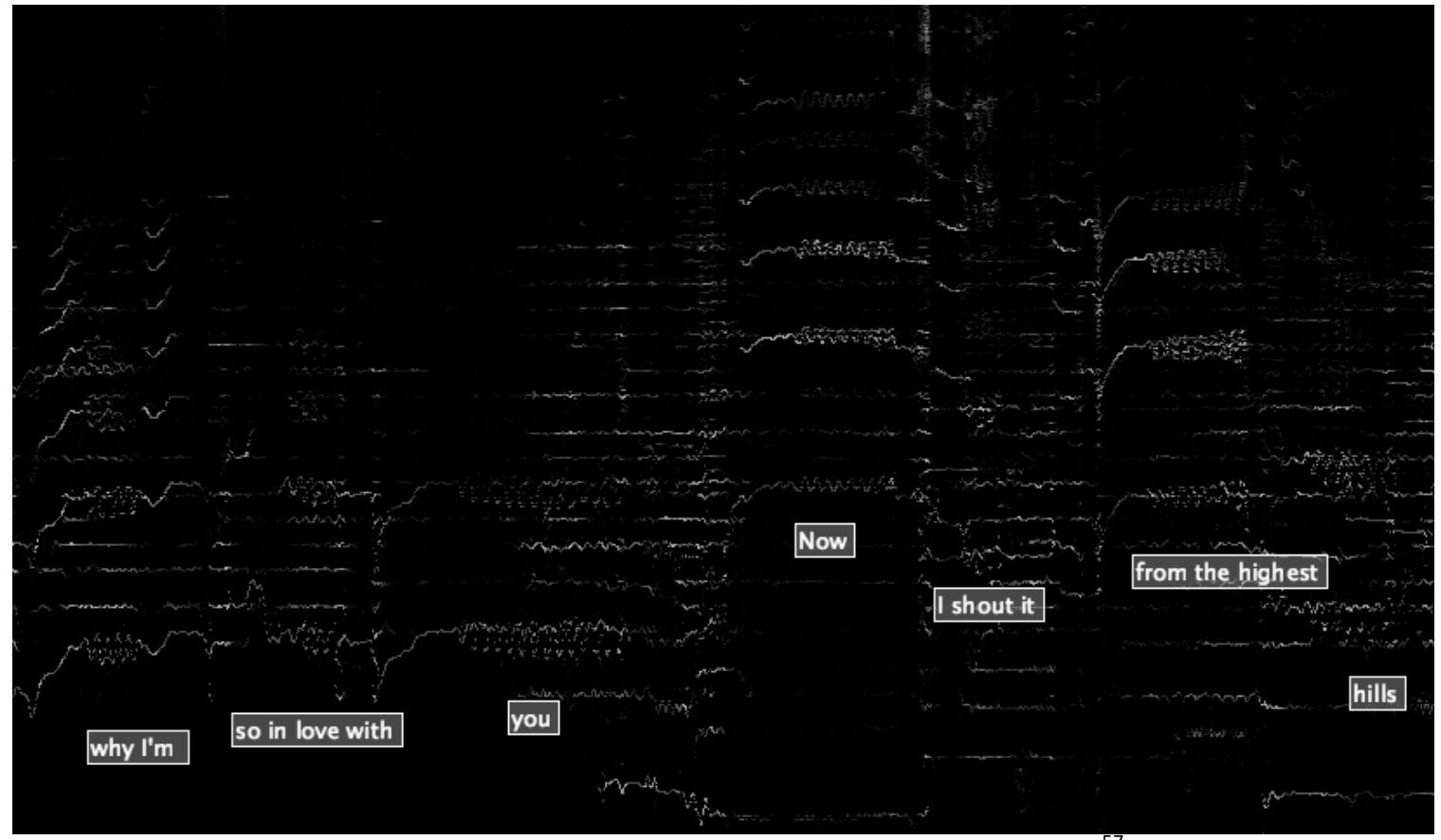

Source: Spectrogram produced by running Day's "Secret Love" in Sonic Visualiser.

Note: The wavy lines immediately above the text boxes represent Day's sung pitches. The "echo" lines that run above in parallel depict overtones. When Day sings "why I'm" and "so in love with you," the sung pitch shows high energy relative to its overtones. (The wavy lines paralleling the sung line are of the same intensity or fainter than the sung pitch.) However, on the word "Now," the sung pitch (represented by the wavy line just above the "Now" text box) is relatively weak in energy compared to its first two overtones. In spite of this, we still experience the pitch on "Now" as B4, the sung pitch. The high energy overtones are experienced by most listeners not as pitch, but as brassy timbre. (As discussed in Chapter 1, high energy an octave above the sung pitch is a hallmark of belting in female singers.)

\section{Sunny in "Whatever Will Be, Will Be (Que Sera, Sera)"}

Presenting a very different affective register than Day's tender ballads is her most well

known song today, "Whatever Will Be, Will Be (Que Sera, Sera.)” Written by Jay

Livingston and Ray Evans, the song was commissioned for the 1956 Hitchcock movie

${ }^{57}$ Chris Cannam, Christian Landone, and Mark Sandler, Sonic Visualiser: An Open Source Application for Viewing, Analysing, and Annotating Music Audio Files, in Proceedings of the ACM Multimedia 2010 International Conference. 
The Man Who Knew Too Much, in which Day starred opposite Jimmy Stewart. The song was released as a single and reached \#2 on the Billboard charts, and received the Academy Award for best song.

The song appears twice in the film. The first instance introduces the tune in its “correct" emotional register: Day's character Jo McKenna sings it to her son while they dance playfully. When the song recurs during the film's climax, Jo sings the song ostensibly to entertain an audience of elite embassy guests, but in fact she hopes to make her presence known to her kidnapped son whom she suspects is being held within earshot. In this second performance, Day sings the song with a loud, almost shrill timbre. Here, I will be discussing the single-release version, which is upbeat and danceable, similar to how Day performs it the first time in the movie.

The single-release version is arranged to present a nonspecific foreign "OldWorld European" flavor — in particular, the prominence of the mandolins could allude to Greece or Italy. Billboard attributes Italian and "Latin" qualities to the recording, calling the song a "whimsical bit of philosophy with Latin Overtones via Neapolitan mandolins and rhythms." $" 58$

The song's speaker quotes the proverbial wisdom—que sera sera, "whatever will be will be"-handed down from her mother and from her "sweetheart." In the song's last verse, the speaker then herself passes the advice on to her own children: she urges them not to worry about things they cannot control or predict. While this advice might strike some as dark or fatalistic, the upbeat musical setting invites the listener to adopt this

\footnotetext{
${ }^{58}$ Billboard, June 2, 1956, 36.
} 
attitude as a practical path to happiness. ${ }^{59}$

Day's performance presents a sunny persona: she comes across as good-humored and cheerful. She does this by exaggerating consonant pronunciation, by strongly accenting the downbeat, and by shifting matter-of-factly between modes of vocal production.

At several points in the song, Day exaggerates the length and strength of consonants, specifically "s" and "ch" sounds. She opens with:

When I was juSSSt a little girl

I asked my mother what will I be

Will I be pretty, will I be riCH

Here's what she said to me

The emphases of the "s" of "just" and the "ch" sound of "rich" convey a kind of harshness or a would-be ugliness. Day might be sliding off of the vowels and onto the consonants because she does not find the vowels easy or enjoyable to sustain. But unlike other instances in which she chooses to dwell on specific syllables because they allow for a more smiley presentation, here the consonant sounds "ss" and "ch" transmit noise more than pitch. And yet, in a fast moving song like this, these "noisy" interruptions pass quickly, and further, they add rhythmic accentuation: they are like unpitched percussion that articulate rhythm and meter. Finally, although these "ss" and "ch" sounds risk sounding "ugly," they are only momentary, and Day absorbs them into an otherwise pleasant vocal line.

\footnotetext{
${ }^{59}$ The actual phrase "Que sera sera" does not belong to any language per se. Its words are Spanish but the syntax is English. It is a centuries old saying used by English-speaking people. See Lee Hartman, "'Que Sera Sera:' The English Roots of a Pseudo-Spanish Proverb," Proverbium 30 (2013): 51-104.
} 
Along the same lines, Day shifts between vocal registers in a way that could risk sounding ugly. The song unfolds in A major, and the range is a ninth, spanning A3 to B4. Given that the "Que sera, sera" chorus starts on the second highest pitch of the song, it is not surprising that Day attacks it with chest voice - this is her surest way of projecting high intensity and of starting the phrase with punch. However, she moves out of chest voice almost instantly: she belts "Que se-" but for "-ra" pulls back to low head voice. The switch is sudden and rather glaring, but gets absorbed into the song's broader aesthetic of practicality, energy and good humor. The potential for jarring due to the sudden moves in and out of belt mode are further moderated by Day's forward drive: she keeps forward momentum by accenting the downbeat in this triple meter song.

\section{Day's films}

Day is probably best known for the musicals Calamity Jane and Love Me or Leave Me and the straight comedies she starred in with Rock Hudson, most notably Pillow Talk. The most critically lauded of all her films is The Man Who Knew Too Much in part because of the prestige now conferred upon the entire oeuvre of director Alfred Hitchcock, though Day's dramatic acting also impressed viewers at the time and still does today.

In her own time, Day received positive film notices starting from her debut in Romance on the High Seas (1948) and these were consistently positive, with her 
performance in Calamity Jane (1953) particularly, through to 1960 . Her critical success started to flag after Lover Come Back (1961) at which point she started receiving negative reviews. Her commercial success faltered a few years later: Move Over Darling (1963) was her last commercial hit. ${ }^{60}$

Although an Academy Award eludes Day to the present — she was nominated but did not win for Pillow Talk—she continually won secondary awards and magazine polls: such as the "most popular actress of the year" title in Photoplay 1952; an award shared with Rock Hudson for the "world's favorite actor and actress" at the 1960 Golden Globe awards ${ }^{61}$ and the Cecil B. DeMille award at the Golden Globes in 1989.

Central to the image Day projected at large were the character types she played onscreen. Discussions about her sexuality in film tend to focus on the latter half of her career in which sexuality is a central topic of the film: the romantic/sexual power plays in Teacher's Pet, Pillow Talk and Lover Come Back, drive the plots of these films. In contrast, the early Day films are sometimes discussed as if Day is removed from the sphere of heterosexual desire.

While she was at Warner's, Day played young women who showed a certain degree of independence or assertiveness that is striking in the context of the postwar era's gender norms. (See table 2.5.) In eight of these films, Day plays an aspiring performer whose dream of succeeding as an entertainment professional fuels her with energy and drive, though never takes on a ruthless ambition. If other characters help her in her quest it is not because she manipulates, or strategizes as to how to use people, but rather

\footnotetext{
${ }^{60}$ Kaufman, Doris Day, 355.

61 Ibid., 274.
} 
because she charms them with her energy and lack of guile.

In three of the Warner's films, Day plays a "tomboy." As the adolescent Marjorie Whitfield in two family films, Day is a loving and agreeable daughter who both endears herself to and worries her parents over her lack of interest in girlish pursuits. In Calamity Jane Day plays a gun-toting frontierswoman. In all three of these films, the Day character "outgrows" her tomboyishness enough to find a heteronormative romantic end with the leading man. However, these film endings suggest that Day's characters will retain their assertive spunkiness even as they adapt to married life. Furthermore, these films do not present a sexually undesirable Doris Day. Day owed her 1947 screen test and initial casting in part to her looks. Though she was not considered an exotic beauty, she was considered attractive, and was particularly admired for her figure. ${ }^{62}$

Day's roles began to change after she left Warner's in 1954. In Love Me Or Leave Me (1955) Day played another aspiring performer: historical singer Ruth Etting. This role marked a dramatic turn for Day because this was her first "non-wholesome" character. For the first time on film, Day's character is not completely guileless: she accepts the help of mobster Marty Synder, while suspecting he may expect sexual favors in return. This is the "raciest" role Day would play. After Love Me or Leave Me, Day's characters resume their tendencies toward charm and positivity reminiscent of her earlier films, even if they are no longer aspiring performers. Instead they are wives, mothers, career women or widows (or various combinations thereof.)

${ }^{62}$ Day's autobiography is replete with comments of friends and associates praising Day's looks. Among them are Les Brown who hired her in part for her "attractive appearance," and Bob Hope who referred to her as "Jut-Butt" because of her "truly great body." See Hotchner, Doris Day: Her Own Story, 40, 100. 
As Day's career progressed into the late 1960s, her reviews declined to the point that she became an object of disdain, as the following New York Times piece suggests:

Doris Day's honor, from movie to movie, was becoming a kind of drag as she tumbled from euphemism to innuendo. The beginning of each movie asked the question whether Anything was going to Happen, the middle raised the desperate possibility that something Had Happened and then .... She was married. ${ }^{63}$

While critics today have legitimate complaints about the declining quality of Day's 1960s films, ${ }^{64}$ the above review is both an overgeneralization of Day's films as a group, and a misreading of individual films. The "preserving her virginity" plot is truly only the plot of one film: A Touch of Mink. In other films in which Day plays a single woman engaged in a "battle of the sexes," her characters are judicious rather than free with their sexual choices, but they do not convey sexual innocence or inexperience. But to a late 1960 s audience, the sexual caution exercised by Day's protagonists seemed prudish in the context of the emerging sexual revolution.

TABLE 2.5 Doris Day's Warner Brothers films (1948-1954)

\begin{tabular}{|c|l|l|l|}
\hline Year & \multicolumn{1}{|c|}{ Title } & \multicolumn{1}{c|}{ Genre } & \multicolumn{1}{c|}{ Character type } \\
\hline 1948 & Romance on the High Seas & Musical comedy & Aspiring performer \\
\hline 1949 & It's a Great Feeling & Musical comedy & Aspiring performer \\
\hline 1949 & My Dream Is Yours & Musical comedy & Aspiring performer \\
\hline 1950 & The West Point Story & Musical comedy & Aspiring performer \\
\hline 1950 & Tea for Two & Musical comedy & Aspiring performer \\
\hline 1950 & Young Man with a Horn & Musical drama & Established performer \\
\hline 1951 & Lullaby of Broadway & Musical comedy & Aspiring performer \\
\hline 1951 & I'll See You in My Dreams & Musical drama & Career woman turned supportive wife \\
\hline
\end{tabular}

${ }^{63}$ Renata Adler, review of Where Were You When the Lights Went Out?, New York Times, August 9, 1968, cited in Kaufman, Doris Day, 413.

${ }^{64}$ Santopietro provides balanced assessments of Day's entire filmography in Considering Doris Day. 


\begin{tabular}{|c|l|l|l|}
\hline Year & \multicolumn{1}{|c|}{ Title } & \multicolumn{1}{c|}{ Genre } & \multicolumn{1}{c|}{ Character type } \\
\hline 1951 & Storm Warning & Drama & Wife \\
\hline 1951 & On Moonlight Bay & Musical comedy & Tomboy-adolescent \\
\hline 1951 & Starlift & Musical comedy & Established performer \\
\hline 1952 & April in Paris & Musical comedy & Aspiring performer \\
\hline 1952 & The Winning Team & Drama & Wife \\
\hline 1953 & By the Light of the Silvery Moon & Musical comedy & Tomboy-adolescent \\
\hline 1953 & Calamity Jane & Musical comedy & Frontierswoman/tomboy \\
\hline 1954 & Lucky Me & Musical comedy & Aspiring performer \\
\hline 1954 & Young at Heart & Musical drama & Daughter/love interest \\
\hline
\end{tabular}

\section{Recent writing on Day's image}

The recuperation of Day's reputation as a valuable performer began with film critic Molly Haskell. ${ }^{65}$ Haskell recuperates Day as both a talented actress, and a feministfriendly icon. Day fulfills a romantic girl-next-door ideal in being positive, popular, and "natural,"- - this is in opposition to Marilyn Monroe and Elizabeth Taylor with their more voluptuous and exotic appeals. Day’s tomboyishness, Haskell argues, brings her into partial alignment with other slightly androgynous Hollywood actresses including Audrey Hepburn and Grace Kelly. In different ways, Haskell argues, these tomboyish females were attractive in part because of the independence they projected. Haskell further dismisses the idea that Day's image was not sexual. Haskell grants that Day's characters are never actively seeking sex; and yet "sex" circles around her characters: she is sexy, sex is at issue, the situations are sexual. ${ }^{66}$

In 1980, feminist film scholars Jane Clarke and Diana Simmonds spearheaded a Doris Day film retrospective for the British Film Institute. Alongside this multi-day event, they published the accompanying dossier, Move Over Misconceptions: Doris Day

\footnotetext{
${ }^{65}$ Molly Haskell, From Reverence to Rape: The Treatment of Women in the Movies, $2^{\text {nd }}$ ed. (1974; Chicago: University of Chicago Press, 1987).

${ }^{66}$ Ibid., 262-268.
} 
Reappraised ${ }^{67}$ In this publication Clarke and Simmonds contextualize the critiques of Doris Day that coalesced in the late 1960s:

Doris Day...has somehow come to epitomize the unacceptable face of that [postwar] period to the post-68 generation. She is associated with a repressive, or at least, normative sexuality. She is the model of 50s and early 60s maidenhood before marriage and heterosexual monogamy afterwards; 2.4 children and a two car household, in short, the cornerstone of the nuclear family. To the post-68-generation the family represents the ideological lynchpin of capitalism, the place where dominant values are perpetuated - encouraging a respect for hierarchies, obedience to 'superiors', the subordination of women and children and the repression of all but a closely bounded and repressed sexuality. ${ }^{68}$

The authors agree that Day's films can trivialize women and women's sexuality. But, they argue, rejecting Day because of her associated postwar values has resulted in neglecting a talented actress who often manages to give feminist-friendly performances despite her material. The authors further argue that far from presenting repressed sexuality, "what few reviewers could come to terms with or understand and what the post-68 generation have little or no conception of is that Doris Day is sexy." $" 69$

Another recuperative impulse in terms of Day's significance comes from author John Updike who famously had a lifelong "crush" on the actress, laid bare in his feature-

\footnotetext{
${ }^{67}$ Jane Clarke and Diana Simmonds Move Over Misconceptions: Doris Day Reappraised, BFI Dossier No. 4 (London: British Film Institute, 1980).

${ }^{68}$ Clarke and Simmonds, Move Over Misconceptions, 1.

${ }^{69}$ Ibid., 7.
} 
length New Yorker review of her memoir. ${ }^{70}$ In this piece, Updike highlights what he finds to be striking revelations made by Day in her autobiography. ("She never watches rushes, and cannot sit through one of her old movies without wanting 'to redo every shot."') But he also offers his own thoughts on what makes Day an appealing and affecting performer: She appears sheer symbol — of a kind of beauty, of a kind of fresh and energetic innocence, of a kind of banality.... Singing or acting, she manages to produce, in her face or in her voice, an "effect," a skip or a tremor, a feathery edge that touches us.

The hardly-complimentary use of the word "banality" is followed later by even more ambivalent praise:

Her starriness has a challenging, irritating twinkle particular to her Monroe's image lulled us like a moon seen from a motel bed, and there is nothing about Katharine Hepburn's “goodness" that asks us to examine our own. On the jacket of "Doris Day: Her Own Story" the sprightly photograph of the heroine uncomfortably reminds us of those tireless, elastic television ladies who exhort us to get up in the morning and do exercises....

And then Updike follows with a surprising comment about his perception of Day's intellect:

\footnotetext{
${ }^{70}$ John Updike, "Books: Suzie Creamcheese Speaks," The New Yorker, February 23, 1976, 109-114.
} 
She became a successful comedienne, surely, in part because she is one of the few movie actresses of her generation whose bearing conveys intelligence. $^{71}$

In a late poem, "Her Coy Lover Sings Out," Updike expresses more plainly the effect Day had on him as he came of age:

Doris, ever since 1945, when I was all of thirteen and you a mere twenty-one, and "Sentimental Journey" came winging out of the juke box at the sweet shop, your voice piercing me like a silver arrow, I knew you were sexy. ${ }^{72}$

Updike's reading of Day is personal and idiosyncratic to be sure. Yet this author was influential and lauded for articulating a bold presentation of male heterosexual desire for his (pre-baby-boom) generation. It is not unlikely that his words capture an aspect of Doris Day's broad appeal as a heterosexual sex symbol for postwar "Middle America," whether or not this was always discussed outright. ${ }^{73}$

While Updike presents a heterosexual view of Day, an alternative literature presents Day as a possible queer subject and object. This is explored in Eric Savoy's

\footnotetext{
${ }^{71}$ Updike, "Suzie Creamcheese," 114.

${ }^{72}$ Updike, "Her Coy Lover Sings Out," in Endpoint and Other Poems (New York: Alfred A. Knopf, 2009).

${ }^{73}$ Numerous summations of Updike's legacy appeared in the mainstream press after this death. See, for example, "Remembering Updike: Paul Theroux," New Yorker, January 28, 2009, and Michiko Kakutani, "A Relentless Updike Mapped America's Mysteries," The New York Times, January 28, 2009.
} 
"That Ain't All She Ain't: Doris Day and Queer Performativity."74 Savoy reviews both the feminist positions presented above (Haskell, Clarke and Simmonds) as well as previous queer engagements with Day's work. Savoy takes the work of Haskell and Clarke and Simmonds to say that many of Day's movies both present conventional ideals of gender and show Day's characters resisting these ideals to different degrees, leaving us with "ideological incoherence" with respect to gender roles and expectations.

Savoy dovetails off of this idea to suggest that several films also invite a lesbian reading, thereby presenting a different kind of incoherence, in this case one to do with heteronormativity. In this way, Savoy sees the ending of Calamity Jane as leaving such an incoherence. Ostensibly, Day's character, the frontierswoman "Calamity" Jane is properly gendered "female" by the end of the film when she realizes her heterosexual love for Howard Keel. Savoy argues that this ending is unconvincing because there have been so many moments of queer desire in the film, and because this ending comes very suddenly. The song "Secret Love," which is, in the film's explicit narrative, an expression of Jane's realization of her (heterosexual) love for Howard Keel, reads just as easily as an act of "self-outing."

Queer readings of Doris Day across several of her films, and in Calamity Jane in particular, point to an important aspect of Day's image and reception. Savoy, in fact, in his essay, draws on ethnographic data by Jackie Stacey that empirically documents a lesbian/queer audience identification/desire with Doris Day in this film. Thus the "problem" of Doris Day's sexuality within a heteronormative context (is she "virginal,"

\footnotetext{
${ }^{74}$ Eric Savoy, “'That Ain't All She Ain't': Doris Day and Queer Performativity,” in Out Takes: Essays on Queer Theory and Film (Durham: Duke University Press, 1999), 51-182.
} 
"wholesome," "sexy" a "girl next door" or a "tomboy"?) finds one helpful resolution in a reading of Day as expressing and representing queer desire. In other words, the reason Day's sexuality resists easy categorization within a heterosexual matrix is because her performances and roles are ill fitted to that matrix to begin with.

Subsequent film scholarship on Day tends to allow for queer and heteronormative interpretations simultaneously. In "Before She Was a Virgin,” Richard Bingham's main claim concerns the decline of Doris Day as a film star after Pillow Talk(1959.) Bingham pins this decline on an industry-wide trend of 1960s film: after this point, Hollywood no longer allowed female film stars as the subjects of comedies-women could only be objects (of desire and/or of ridicule) in film comedy. Bingham agrees with the feminist readings of Day that argue for Day's skill as an actor and comedian and he agrees with these writers that in several of the earlier films, Day portrays compellingly strong characters who find a happy ending on their own terms. Furthermore, Bingham in effect redeems Day as a performer for the later films, arguing that the declining quality of these films do not stem from a decline in Day's powers, but from increasingly diminished roles with which no actress could create inspiring performances.

While Bingham's article is very helpful in illustrating the shift in the film narratives over Day's career, and he is successful at "absolving” Day for the declining quality of her films, Bingham's descriptions of Day's image in terms of gender and sexuality leave open some interesting questions. For example, he cites a series of Day's detractors who view Day as "sexless," but he also acknowledges that both co-workers to Day and onscreen characters expressed sexual desire for Day. Bingham concludes that 
Day's "unwittingness" as to her sexual appeal is what makes her "sexless" to some observers. I wish to complicate that conclusion in suggesting that Day's sexual appeal is better understood as "safe" rather than "unwitting."

\section{Historical press on Day's image}

As discussed above, Day's reputation as a singer with a sultry/sexy vocal persona was established as early as 1945 through Billboard reviews. The following Billboard advertisement copy makes it clear that Columbia sought to project Day as a "vocal" sex symbol. In his inaugural advertisement "column," The Pitch from Mitch, Mitch Miller uses chatty, "with-it" language to promote Day's latest single, "A Guy is a Guy":

This pitch is going to be more in the nature of a wind-up. They were looking around for someone to tell you about the records we're turning out right now, and somebody said, "Ask the man who makes ' em.” So here I am with my reed dry....So the question you want answered is "What"ve you got?"....The answer, boys, is “What do you want?”...Maybe something on your shoulder, right next to your ear. Something with a little s-x? There's Doris Day in a sensational performance of $A$ Guy is a Guy. The way Doris coos the lyrics in this is enough to start steam coming out of your ears, and there's nothing like that to call the citizens into the shops. $^{75}$

The way Miller describes "A Guy is a Guy" makes it clear that he is certain that sexuality and sexiness can be heard in Doris Day's performance of this song, and that the

\footnotetext{
${ }^{75}$ Mitch Miller, “The Pitch From Mitch,” Billboard, March 8, 1952, 25.
} 
song as a whole is "about" sex.

Billboard was also straightforward in admiring Day's physique from the outset of her career. In this review, the writer admonishes the Les Brown band for drowning out its "girl singer," who nevertheless impresses with her voice and physique: "Ork missed out in backing its own canary, Doris Day, a luscious blonde with a pleasant voice and plenty in the body department. Time and again the brass or the sax section was too loud for the thrush."76

In the popular press outside Billboard, Day's status as sexy comes across with more of a sense of contradiction. She is deemed attractive and engaging but not necessarily "sexy." For example, in an LA Times profile of Doris Day in the wake of her debut film Romance on the High Seas, the author notes that Day is "not a glamor girl in the accepted Hollywood sense," but owns that Day has "an expressive face" and an "infectious" smile. Yet, the author also says Day has a "come-hither voice" ${ }^{77}$ which suggests a sexual dimension to Day's appeal that he has otherwise denied in the article.

A Chicago Tribune article states that Day's appeal is "different" and that therefore an explanation is required:

We asked S.Z. (Cuddles) Sakall [Day’s German-born costar] over a recent Imperial House luncheon just what Doris has that makes the difference. Was it the little girl grin? The off center freckles? The ski jump nose? Or that "Hey fellas!" approach? Sakall has appeared in both of Doris' movies,

\footnotetext{
${ }^{76}$ Review of Les Brown Band, performing at the Capitol, New York City, October 25, 1945, Billboard, November 3, 1945, 38.

${ }^{77}$ John L. Scott, "It's Magic How Doris Day Sings Way to Film Peaks," Los Angeles Times, February 27, 1949.
} 
her boisterous debut in "Romance on the High Seas" and her newest, "My Dream is Yours," at the Chicago theater. Our own crush on this buoyant blonde dates back to her groovy-smoothie chirping in Les Brown's orchestra - long before the minx had a mink - but she had the difference even then. $^{78}$

Here, the author suggests on the one hand that Day is attractive to the extent that she invites a "crush," and yet that her appeal is different enough from what is typically considered attractive. She has physical features associated with girlishness (her "grin," her freckles, her ski-jump nose) rather than mature female beauty; and the winning aspects of her demeanor (she is "buoyant" and has a "hey fellas!" approach) also suggest an unabashed youthful exuberance rather than the poised demeanor we might expect from a Hollywood glamour icon. Lastly, the term "minx" usually connotes flirtatiousness, which in itself often suggests a kind of sexual self-awareness.

Personality/gossip columnist Hedda Hopper is the first to call Day the "Girl Next Door.” Hopper's July 1950 article is entitled "Sunny Doris Day Swinging to Drama: Wholesome Motion-Picture Singer Trying Her First Straight Part" and features a photo with the caption "Girl Next Door - Doris Day has turned a pleasant singing voice and exuberant charm into successful career. At Warner Bros. Doris soon will try straight drama." Hopper says that on first meeting Day, "I was immediately struck by her frank,

\footnotetext{
${ }^{78}$ Savage, "Tower Ticker,” Chicago Tribune, April 18, 1949.
} 
wholesome, well-scrubbed look. Her conversation was frank as her looks and she had personality to match."79

In 1952, Hopper presents another piece on Day, this time both demonstrating and denying Day's sexuality. The text of the article expounds on Day's "wholesome" lifestyle: she goes to bed at $9 \mathrm{pm}$ and rises at 7 every morning. She and her husband are very practical as opposed to being "frivolous" or "debauched" Hollywood types: on the night of their marriage, they came home and watched television. The photo accompanying the article, though, is a full-length shot of Day in a strapless bathing suit. Day's body is lean rather than voluptuous, but it certainly boasts feminine contours that would be considered sexually attractive to many viewers. The caption under the photo reads,
Although Doris Day's husband insists she's just a "talented girl whom circumstances pushed into the limelight," this picture reveals that she has captivating beauty as well as talent. In new film, she even turns to serious role. $^{80}$

This is a bizarre caption, because a "bathing suit shot," while it can certainly demonstrate a subject's (facial) beauty, is typically used to showcase the subject's body, and to portray the subject as an object of sexual desire. In a way, this article is trading on Day's bodily/sexual appeal but denying this appeal when it comes to the verbal description.

\footnotetext{
79 Hedda Hopper, "Sunny Doris Day Swinging to Drama: Wholesome Motion-Picture Singer Trying Her First Straight Part," Los Angeles Times, July 23, 1950.

${ }^{80}$ Hedda Hopper, "Hedda Takes it Down as Doris Day Talks," Los Angeles Times, June 8, 1952.
} 
This juxtaposition between sexually alluring photograph on the one hand, and the prose description of Day is strange indeed. The article's text presents Day as not merely sexual within appropriate boundaries, but rather purports to present Day's marriage to husband Marty Melcher as sexless or sexually uninteresting. The contrast could work in at least one of two ways: it could be that the bathing suit photograph is so blatant in its depiction of Day as an object of sexual desire that the text description of her seemingly "undersexed" marriage balances the total effect of the text-photo combination. An alternative explanation is that readers who might desire Day and would prefer to fantasize about her as available as opposed to being married, are closer to being able to do so, since the marriage to Marty Melcher is described more in terms of companionship than sexual passion.

In 1955, Day starred in Love Me or Leave Me, and much was made in the press of this being a change in her image. This January 21955 Washington Post article states that Day is moving away from her "girl next door" image and embracing a "sexier" one, Doris Day, who made a mint at the box office playing the girl next door, will move in 1955 to a sexier medium... In "Young at Heart," she delightfully fills a bathing suit for the first time on the screen and in "Love Me or Leave Me" she slithers through the gangster-speakeasy era. ${ }^{81}$

The Chicago Tribune gives Day a soapbox to contemplate her own image in relation to sexuality in July 1956:

Doris Day, who made a mint at the box office as the girl next door,

81 “Doris Day Gets a New Pace," Washington Post, January 2, 1955. 
believes the time has come to be known instead as the woman down the street. In brief, Doris has decided to be sexy—if the part calls for it. "It was a tough decision," she confides, "but I'm resolved now not to make a detour every time the subject of sex comes up. If I do, I haven't much chance of advancing as a dramatic actress....I don't want anyone to think I'm advocating sex for the sake of sensationalism," she cautions. Doris, who can wear a bathing suit like Marilyn Monroe, doesn't regard herself as sexy. "It's such a physical word," she explains, "and a little vulgar. I'm striving for more adult roles, but I won't be putting on tight skirts or revealing negligees." 82

Day's comments suggest that she understands that she has up to now been projecting a kind of femininity that was considered distinct from more obviously sexually appealing figures like Marilyn Monroe. Further, Day’s comments about her move to be "sexier” suggest that she is aware that something has been "sexually safe" about her appeal so far; and that she wants old fans to follow her change of image without worrying that her more sexually mature portrayals will offend them. And yet, it is improbable that Day could suddenly "become" sexually attractive to audiences if she didn't already possess some kind of sexual appeal before then, despite accounts that deny this. What is more likely is that the film scripts from 1955 onward make sexuality more of a topic than it had been in her previous films. In early films, Day plays tomboyish adolescents or exuberant ingénues none of who concern themselves with attractiveness and sexual appeal. And yet

\footnotetext{
${ }^{82}$ James Bacon, “Doris Day to Try for Sexy Movie Roles," Chicago Tribune, July 8, 1956.
} 
Day the actress likely invited sexual desire from at least viewers right from the beginning.

The following 1959 article by Hopper makes more clear the kind of sexual desire certain audience members may have always harbored for Day, even in her "Girl Next Door" phase. Hopper surveys the positive acclaim for Day in the UK as of the recent British release of It Happened to Jane. Hopper quotes one of the "toughest critics" who writes:

There's something about Doris Day that seems to bring out the boyishness in most of the middle-aged men I know. The moment her short hair and freckled face appear on screen the sap begins to rise in them and they suddenly realize it's spring again. 'Let's be off to the woods and gambol with Doris,' you can almost hear them say. I can't blame them for these daydreams. She's the freshest, cleanest, and wholesomest thing on screen today. And never for a moment is she prim or prissy. ${ }^{83}$

In her own voice, Hopper continues, They're so right about Doris. Off screen and on she's found the secret of how to remain fresh and at the same time never dull or boring. She never thought she had to resort to the kind of roles that earn Hollywood dames salty headlines and an unwelcome reputation. .... Doris proved her talent for heavy drama in "The Man Who Knew Too Much," "Julie," and "Love Me Or Leave Me," and now is sticking to bright comedies. Even tho

\footnotetext{
${ }^{83}$ Hedda Hopper, "Doris Day's Career is Bright as a Sunny Day,” Chicago Tribune, June 9, 1959.
} 
producers keep insisting moviegoers no longer pay to see funny films, the public loves them if they get good ones. The same experts believed that Doris was risking her career when she announced she'd do six straight comedies, but her stock is still rising.

This is an interesting article in both content and form. Hopper inserts into her article a description of the sexual desire Day can incite in "middle-aged men," but Hopper does so by quoting an unnamed male critic from the UK, who himself projects desire for Day onto "most of the middle-aged men I know." This distance allows Hopper to point to Day's erotic appeal without naming it. When Hopper comes back in her own voice, she "cleans up" any remaining notion that Day might be actively, assertively or threateningly sexual in ways that push against norms. Day's choices have allowed her to avoid "salty headlines and an unwelcome reputation."

These historical pieces taken together suggest that it is unlikely that many audience members experienced Day as asexual, or non-sexual or as not sexually appealing. It is true that Day's potential sexual appeal is not what necessarily jumped out at audiences in the way it might have for Marilyn Monroe, and it is also true that some commentators take pains to distinguish Day from more obvious sex symbols like Monroe. It appears as though audiences are able to enjoy Day both for her sexual appeal and for her other "wholesome" qualities, qualities which ironically suggest that she is not aware of or concerned with honing her sexual appeal. This makes Day a safe object of sexual desire. 


\section{Safe sexuality}

Day invited sexual desire of her audiences as a singer and an actress and yet many discussions of her image deflect or disavow that status to different degrees and in different ways. This paradox makes Day a fitting sex symbol for the postwar era and its conservative gender norms.

The postwar era was an era in which a new iteration of traditional gender roles was superimposed on a decades-old movement toward sexual liberalism. John D'Emilio and Estelle Freedman as well as Jane Gerhard show how in the 1920s, the Victorian marriage ideals that emphasized control gave way to the belief that mutual sexual enjoyment was an important component of modern marriage. ${ }^{84}$ Ben Lindsay and Theodore Van Der Velde were among the authors of marriage manuals advocating that husbands and wives cultivate engaged and satisfying sexual relationships within otherwise traditionally structured marriages. ${ }^{85}$ While it is true that these authors discussed sexual relationships and techniques strictly in the context of marital relationships, a trend of sexual permissiveness grew in the 1920s and 1930s even in dating and non-marital situations. Part of this was because young people began to date without chaperones giving them more (if limited) chances to experiment sexually than they had had under chaperoned dating systems. ${ }^{86}$

Even as a general ethos of liberalism unfolded, it did so differentially across gender and class boundaries. Middle-class men, for example, sometimes sought non-

\footnotetext{
${ }^{84}$ John D'Emilio and Estelle B. Freedman, Intimate Matters: A History of Sexuality in America (New York: Perennial Library, 1989); Jane F. Gerhard, Desiring Revolution: Second-wave Feminism and the Rewriting of American Sexual Thought, 1920 to 1982 (New York: Columbia University Press, 2001). ${ }^{85}$ Gerhard, Desiring Revolution, 2001.

${ }^{86}$ D'Emilio and Freedman, Intimate Matters, 262.
} 
marital sexual encounters with working-class women but might still expect middle-class partners to be "chaste." ${ }^{87}$ In general, a gendered double standard required women to enforce boundaries during romantic/sexual encounters. Women sometimes negotiated the double standard by allowing sexual permissiveness in the context of more affectionate or more serious relationships, especially if these seemed like they were headed to marriage. ${ }^{88}$ Elaine Tyler May has shown that many middle-class married couples of the 1950s went into marriage with sexual experience. ${ }^{89}$

Postwar Americans had greater expectations of fulfilling sexual experience within marriage (and possibly before marriage) but they were also surrounded with more overt discussion and presence of sexuality in media and discourse. The Kinsey Reports on male sexuality and then female sexuality were published in 1948 and 1953 respectively, further normalizing sexuality as a healthy part of happiness and fulfillment..$^{90}$

Yet the postwar era introduced a new social edict on top of this one: marriage was the most desirable state for an adult; and stable nuclear families were the ideal social organization. In Homeward Bound, Elaine Tyler May argues that men and women of the postwar era saw marriage and nuclear family in a suburban home as a way to ensure stability, peace and security during a politically tense era. ${ }^{91}$

The dramatically pro-marriage culture was somewhat at odds with the growing sexual permissiveness of the previous decades. While couples were encouraged to seek

\footnotetext{
${ }^{87}$ Ibid., 263-4.

${ }^{88}$ Ibid., 263

${ }^{89}$ Elaine Tyler May, Homeward Bound: American Families in the Cold War Era, Revised and updated (New York:, Basic Books, 1999), 101-2.

${ }^{90}$ Alfred C. Kinsey, Sexual Behavior in the Human Male (Philadelphia: Saunders, 1948); Institute for Sex Research and Alfred C. Kinsey, Sexual Behavior in the Human Female (Philadelphia: Saunders, 1953).

${ }^{91}$ May, Homeward Bound, 14.
} 
sexual fulfillment in the marriage bed, the domestic-values culture made the idea of presenting sexually enticing material in media a thorny one. May notes that film and television of the 1950s began to more strongly differentiate between "good" and "bad" sexuality in women, where "bad" sexuality was threatening to men's power and family stability. ${ }^{92}$

Day was a safe sex symbol for an era during which, on the one hand, sex was increasingly a subject of thought and discussion, and on the other, during which efforts were applied to keep sexual energies channeled into the sanctioned arenas of domesticity and marriage. From the moment she entered the public eye, Day drew reactions that pointed to a sexual appeal of her body and voice; but increasingly, these were interspersed or replaced by comments that either deflected this appeal, or focused more on her "wholesome" qualities, and her winning personality.

Viewed in this way, Doris Day the singer and actress was never not a sexual icon. She was simply a safe one. Commentators who heard her sing before she made films, and audience members who saw her perform live in the years before 1947, found her attractive and sexy, not simply "sweet” or "girlish. In her Warner's films, Day played artless, non-threatening characters. Yet in these same films, Day's physique, her smile and her voice invited sexual desire, even as the plots and her reception discourse constantly circled around this fact.

\footnotetext{
${ }^{92}$ May, Homeward Bound, 54.
} 
Doris Day is better known today than many postwar pop singers. While this is largely because of her status as a film icon, it is also true that several present-day critics argue for a reevaluation of her talents as a singer. In some circles, then, Day stands to gain canonic permanence as a vocalist who is comparable, if not equal, to jazz and pop favorites like Ella Fitzgerald or Frank Sinatra. Meanwhile, the image Day projected in film continues to generate a variety of responses including unbridled admiration, and engaged, critical discussion. In this chapter, I have sought to contribute to the discussion on Day's cultural significance by focusing on her work as a singer and then approaching her film image with her vocal persona as a point of departure.

An in-depth analysis of Day's singing reveals what I have termed a "workaround" vocal technique. Day does not demonstrate the same robust technique as some of her peers when it comes to vocal tone and negotiation of registers. But her formative vocal training emphasized expressiveness and communication, and she harnessed her vocal "flaws" to these ends, allowing her to imbue her songs with varied personae: sultry/sexy, tender, and sunny.

The tender and sunny personae Day reflects in her recordings are mirrored by the images she projects in film over approximately the same years. In Day's seventeen Warner films she regularly portrays characters who are earnest, positive, and energetic; and who, when stopping for a moment to sing a love ballad, become tender, conveying direct and palpable warmth. However, Day's sultry/sexy vocal persona does not have an obvious mirror in her Warner's films. These film characters never exude explicit sexual desire nor are involved in explicitly sexual scenarios. And yet, in these same films, Day 
the actress is always a physically appealing presence, and this was not lost on observers of her day, even though writers were inconsistent and sometimes circuitous in how they acknowledged her sexual desirability, if they did so at all.

I have suggested that the Doris Day who appeared on records and in the Warner films up to 1954 was a "safe" sex symbol, highly suitable to her time. The postwar domestic revival, with its emphasis on marriage and child rearing, superimposed an ethic of sexual conservatism overtop of a trend toward sexual liberalism that had begun in the 1920s. The fact that Day and her co-creators in film and recording both allowed and moderated her presentation of sexuality invites us to read Day in ways other than as a mere casualty of 1950 s postwar norms, or as a sexual innocent, or as an unwitting sex object oblivious to her appeal. Rather, it makes more sense to think of Day as in tune with her times, and acting on an instinct in a way that allowed her to present sexual desire and desirability through music and film, along with her other cherished qualities in ways that worked within the thorny and contradictory norms of the time. In this way there are parallels between her adoption of "workaround" vocal technique and her ability to work around (and through and beside) the gender and sexuality and rules of her era. 


\section{Patti Page: Placidity, Poise and Power}

Patti Page died on January 1, 2013, at the age of 85 . Her death prompted the usual obituaries in the press, but did not stimulate reconsiderations of her output. The smoothvoiced singer of "Tennessee Waltz" and "Doggie in the Window," the most commercially successful American performer between 1950-1954, holds little appeal for modern listeners.

When we try and understand Patti Page's dramatic postwar popularity, a typical, "common-sense" explanation is that she reflected the mood, or the essence of the postwar era. For example, New York Times critic Jon Pareles says in his review of Page's 1997 Carnegie Hall concert that, "her voice is still rich and steady, and only a little less sweet than it was in her 1950s heyday, when her even-tempered singing was just what America wanted. As World War II ended and the prosperous 50's began, the American middle class enjoyed contentment and a clear conscience."

It may be true that even-temperedness was a quality of Page's singing that appealed to postwar listeners. But critics who explain Page's popularity by citing the historical tenor of the times end up gliding over the specifics of her singing and they fail to clarify why Page drew more listeners than did, for example Doris Day, Rosemary Clooney, or Jo Stafford, or for that matter male, singing sensations Bing Crosby and Frank Sinatra.

Page had both a strong audio and visual presence in popular culture. As well generating 34 singles that charted on the Billboard top 20, she appeared on several

\footnotetext{
${ }^{1}$ Jon Pareles, "Still Hearing that Tennessee Waltz," The New York Times, June 2, 1997.
} 
television shows during the $1950 \mathrm{~s}$, both as guest and host. (See tables 3.1 and 3.2.) She also continued to tour regularly, balancing live concerts with studio recording and television activities throughout the 1950s.

A strikingly photogenic woman, Page cultivated a glamorous and refined look. Advertisements, sheet music, and record covers provided countless opportunities to showcase her face and body, her elegant hairstyles and increasingly luxurious fashions. In this way, Page embodies a kind of "ultra-feminine" postwar femininity, and the yielding body language and demeanor she presents in still and moving images only reinforces this. Her projection of placid femininity in images can easily dovetail with the even-tempered, steadiness of her voice to bolster our impression that Page was the ultimate "conformist" female icon of postwar mainstream music: she gave a voice and a look to re-vamped but essentialist images of womanhood.

In fact, Page's projection of placidity and ultra-femininity cannot explain the popularity of her music if it explains it at all. Historical reception of her recordings does not turn on descriptors like "passive" or "soothing." While many historical reviewers praised Page for her vocal "warmth," they were just as likely to attest to her vocal "power." To understand Page's particular reign over the mainstream pop music world, then, it is necessary to understand more about how and why this vocal "power" was experienced in its day. I argue that it stems in part from Page's vocal production and technique, which bears some resemblance to classical singing. This power was only heightened through her display of versatility across pop styles, and her records' production, which showcased her singing in uncannily blended duos, trios and quartets, 
thanks to the then-novel technique of multitracking. This chapter will show how Page's

vocal and visual image blended power and placidity.

TABLE 3.1 Hit singles recorded by Patti Page

\begin{tabular}{|c|c|c|}
\hline Year & Song & Top chart position \\
\hline 1948 & Confess & 12 \\
\hline 1949 & So In Love & 13 \\
\hline 1950 & With My Eyes Wide Open & 11 \\
\hline 1950 & I Don't Care if the Sun Don't Shine & 8 \\
\hline 1950 & All My Love & 1 \\
\hline 1950 & Tennessee Waltz & 1 \\
\hline 1951 & Would I Love You & 4 \\
\hline 1951 & Mockin' Bird Hill & 2 \\
\hline 1951 & Down the Trail of Achin' Hearts & 17 \\
\hline 1951 & Mister and Mississippi & 8 \\
\hline 1951 & Detour & 5 \\
\hline 1951 & And So to Sleep Again & 4 \\
\hline 1952 & Come What May & 9 \\
\hline 1952 & Whispering Winds & 16 \\
\hline 1952 & Once in a While & 9 \\
\hline 1952 & You Belong to Me & 4 \\
\hline 1952 & I Went to Your Wedding & 1 \\
\hline 1952 & Why Don't You Believe Me & 4 \\
\hline 1952 & Conquest & 18 \\
\hline 1953 & Doggie in the Window & 1 \\
\hline 1953 & Butterflies & 10 \\
\hline 1953 & This is My Song & 20 \\
\hline 1953 & Changing Partners & 3 \\
\hline 1954 & Cross Over the Bridge & 2 \\
\hline 1954 & Steam Heat & 8 \\
\hline 1954 & What a Dream & 8 \\
\hline 1954 & I Cried & 13 \\
\hline 1954 & The Mama Doll Song & 11 \\
\hline 1954 & Let Me Go Lover & 8 \\
\hline 1956 & Go On With the Wedding & 11 \\
\hline 1956 & Allegheny Moon & 2 \\
\hline 1956 & Mama From the Train & 11 \\
\hline 1957 & Old Cape Cod & 3 \\
\hline 1957 & Left Right Out of Your Heart & 9 \\
\hline
\end{tabular}

Source: Whitburn, 2001; Whitburn 2002. 
TABLE 3.2 Patti Page's television shows

\begin{tabular}{|c|l|l|}
\hline Year & \multicolumn{1}{|c|}{ Show } & \multicolumn{1}{c|}{ Notes } \\
\hline 1952 & Scott Music Hall & $\begin{array}{l}\text { First aired October } 8^{\text {th }} \text { on NBC. Each episode } 30 \text { minutes } \\
\text { long. }\end{array}$ \\
\hline 1955 & Songalongs & $\begin{array}{l}\text { CBS, syndicated internationally. 15 minute musical shows, } \\
\text { broadcast twice weekly for 52 weeks. }\end{array}$ \\
\hline 1957 & The Big Record & $\begin{array}{l}\text { First aired September } 18^{\text {th }} \text {. Aired live from 8-9pm on } \\
\text { Wednesday nights. Designed to compete with Your Hit } \\
\text { Parade. Feature Vic Schoen Orchestra. }\end{array}$ \\
\hline 1958 & The Oldsmobile Show & Last episode May 16, 1959. \\
\hline
\end{tabular}

Source: Page, This is My Song, 2009.

\section{Hearing Page today}

Although Page does not receive much attention in scholarly or journalistic circles, she is generally the recipient of certain goodwill from those who do write about her. In January 2013, Page's obituary-writers were kind to this singer from days gone by. For example, the New York Times called Page a "honey-voiced alto" whose hits were "soothing, sentimental," if "sometimes silly."2

This was not a case simply of speaking kindly of the dead. From the 1970s onward, a small number of critics covered Page's live shows and doled out muted praise as she continued to tour around the country long after her heyday of the 1950s. Will Leonard says of her 1975 Chicago performance that Page "sings schmaltzy songs in a schmaltzy style, and does it so beautifully she has a niche all her own." ${ }^{33}$ About her New York concert in 1990, John Wilson says, "her approach to her songs is straightforward

\footnotetext{
2 Anita Gates, "Patti Page, 'Doggie in the Window' Singer, Dies at 85," The New York Times, January 2, 2013.

${ }^{3}$ Will Leonard, “Down Home with Patti," Chicago Tribune, October 3, 1975.
} 
and largely unadorned," and that there is a "soft coloration of Miss Page's Oklahoma twang [that] gives her singing an identity."4

In his 1997 review, Jon Pareles reflects on the fact that Page's vocal style might sound unimpressive today, since she hails from the pre-rock era: he says that she sings with "perfect enunciation, foursquare timing and soothing vibrato," but that we might find her lacking today: "to rock-trained ears, Ms. Page sounds placid, almost oblivious.",

Music writers Colin Escott and Karen Schoemer go to greater length to understand Page's oeuvre and legacy: each includes a chapter on Page in their books on the once admired but now neglected pop music of the $1950 \mathrm{~s} .{ }^{6}$ "Who else could tackle Patsy Montana's 'I Want to Be a Cowboy's Sweetheart' as convincingly as Noel Coward's 'Mad About the Boy'?” Escott asks about Page, in appreciation of her high competence in singing postwar genres and styles. ${ }^{7}$

Schoemer engages even more thoroughly with Page's legacy of hits than Escott. She takes a sympathetic approach to Page's music, and describes her own path to appreciating the singer:

When I first started listening to Patti, I have to admit I was underwhelmed....After listening to a bunch of her albums I could hardly remember anything I'd heard.... Least compelling were her versions of standards like "What'1l I Do" and "Dancing in the Dark." She lacked the

\footnotetext{
${ }^{4}$ John Wilson, "Easy Sound of Patti Page," The New York Times, July 5, 1990.

${ }^{5}$ Pareles, New York Times, Jun 2, 1997.

6 Colin Escott, "Patti Page: Oklahoma Blues" in Roadkill on the Three-chord Highway : Art and Trash in American Popular Music (New York: Routledge, 2002), 57-70; Karen Schoemer, "Patti" in Great Pretenders : My Strange Love Affair with '50s Pop Music (New York: Free Press, 2006), 23-40. ${ }^{7}$ Escott, "Patti Page," 69-70.
} 
nuance to give the lines the sophisticated readings they deserved; she applied an even coat of regret from beginning to end, without modulating the drama. ${ }^{8}$

However, as Schoemer continues to listen to Page, her appreciation for the vocalist grows: “The more I listened, the more I realized I wasn't giving her enough credit. Patti's even-temperedness may seem like a deficit to those of us who came along later and grew up with the raucousness of rock and roll. But if you pay close attention, you realize the equanimity was also the seed of her greatest virtue."

Schoemer's chapter includes an account of her time spent with Page in conducting the interview. The author reflects on how Page herself exuded a soothing quality that Schoemer experienced as very pleasant; the author felt a tinge of melancholy when the interview was over. She concludes her chapter by attributing Page's soothing essence, and the quality of her music, to something particular about the 1950s:

We have this idea of how bland and repressive and unexciting the fifties were, yet watching Patti [in old television clips] that day, those qualities didn't seem so horrible.... I've had a whole lifetime of angsty music and clangy guitars and pummeling rhythms. Patti's easygoing simplicity made me want to cry with relief. I'm not saying those extreme emotions don't have an important place in our lives. But how nice, once in a while, to steal away and stop thinking so hard and allow yourself to be soothed. ${ }^{10}$

${ }^{8}$ Schoemer, "Patti," 33.

9 Schoemer, "Patti," 34.

${ }^{10}$ Schoemer, "Patti," 35. 
For Schoemer, this marks a sort of epiphany: as a rock journalist who came of age in the 1970s, she is here granting that other popular musics, displaying contrasting aesthetics and emotions from the rock and punk she grew up with, have their "use." Having accepted that one of music's "uses" may be to soothe, Schoemer can now understand Page's historical appeal and even enjoy her music. This is a wonderfully evocative chapter with which Schoemer kicks off a thoughtful book that interweaves personal anecdotes, rigorous research and self-examination with regard to taste and values. What I wish to interrogate, however, is Schoemer's assumption that there is something “essential" about Page's soothing quality that is in turn a direct channeling the of placid qualities of the 1950s.

\section{Postwar placidity}

Whether or not Page's appeal rested firmly on her presentation of placid femininity, I certainly grant that this kind of femininity was encouraged and idealized in the postwar era. Social historians have shown how the postwar era saw a rearticulation of $19^{\text {th }}$ century ideals around femininity, domesticity and the gender divide. They attribute this to demographic shifts after World War II and the tensions of the Cold War that ensued.

William Chafe sees the rise of postwar traditional doctrine as fallout from the war, during which large numbers of women had worked in important, well-paying jobs. While women's wartime employment experiences did not significantly change their postwar job prospects, it did being to shift their attitudes: "the content of women's lives had changed, 
and an important new area of potential activity had opened up to them." 11 Women had new self-perceptions about their potential for outside employment and were in a good position to question the validity of ideas about a woman's traditional place. Chafe sees the renewal of anti-feminist ideas in the postwar era as a backlash against women who would start to pose these questions. ${ }^{12}$

Elaine Tyler May suggests that traditional roles were strongly emphasized after the war for reasons to do with political stability. In Homeward Bound, she argues that there was a connection between political/military containment abroad and the selfcontainment and emphasis on stable domesticity. In the days of the Cold War, politicians sought means to prevent or suppress political discord or disturbance that was thought even remotely to suggest Communist affiliation. Politicians hoped that if Americans could find material security, emotional comfort and pleasure and amusement in the confines of the single-family home, they could be discounted as potential political threats. As May puts it, "Domestic containment and its therapeutic corollary undermined the potential for political activism and reinforce the chilling effects of anticommunism and the cold war consensus." 13

Whether compelled by demographics or politics or other reasons, postwar authorities began to assert theories about the importance of divided gender roles. Chafe shows how psychiatrists argued that the "natural" place of women was at home. Chief

${ }^{11}$ William Chafe, The American Woman: Her Changing Social, Economic, and Political Roles, 1920-1970 (New York: Oxford University Press, 1972), 195.

${ }^{12}$ Chafe points out that the "feminine mystique" was not a novel phenomenon. Rather it was a rearticulation of the "cult of true womanhood" that pervaded nineteenth century culture. See Chafe, The American Woman, 231.

${ }^{13}$ Elaine Tyler May, Homeward Bound: American Families in the Cold War Era (New York: Basic Books, 1999), Xxv. 
among these were Ferdinand Lundberg and Marnya Farnham, who proposed a concerted program to restore the prestige of the sexually ordained roles of wife and mother. Specifically, they urged a governmentsponsored propaganda campaign to bolster the family, subsidized psychotherapy for feminist neurotics, cash subsidies to encourage women to bear more children, and annual awards to mother who excelled at child rearing. [They] insisted the women could achieve mental sanity only if they reclaimed the home as the central focus of their existence.

Housewives had to repossess the duties from which they had been displaced and the revival of such lost arts as canning, preserving, and interior decorating. ${ }^{14}$

Farnham and Lundberg argued that it was imperative for women to adopt traditional gender roles for the good of society and for their own well-being.

Advice about appropriate gender attributes and feminine behavior was also disseminated in women's magazines. May documents the messages women received about cultivating a rejuvenating and serene demeanor after the war:

Listen to your laughter...let it come easily, especially if you're with boys who have had little to laugh at for too long. Laugh at the silly things you used to do together...And if you hear your laugh sound hysterical, giddy or loud, tone it down...Serenity is the wellspring of the romantic look...This Christmas, with our men home, surely we should know serenity. So let us

\footnotetext{
${ }^{14}$ Chafe, The American Woman, 206.
} 
look happy and contented and starry-eyed. ${ }^{15}$

Chafe shows how the suburban wife was urged to create an atmosphere of calm and respite for her family:

Perhaps most important, the suburban wife was expected to make the home an oasis of comfort and serenity for her harried husband. "Modern man needs an old-fashioned woman around the house," the novelist Sloan Wilson declared. Newsweek stressed the importance of a woman understanding the tensions of her husband's job, and in its "Blueprint for a Wife" emphasized how crucial it was for her to be a "model of efficiency, patience and charm.",16

Coontz documents the media impetus for women to adopt roles as caregivers and rejuvenators. Magazine writers argued that a wife should make a special point of deferring to her husband's needs and wishes. "He's the head man again," the magazine House Beautiful reminded its female readers. "Your part...is to fit his home to him, understanding why he wants it this way, forgetting your own preferences." ${ }^{, 17}$

Through formal and more popular channels, women received the message that they would be happiest in adopting traditional gender roles and that they ought to cultivate soothing and serene demeanors that would help them to create comfort and rejuvenation for their husbands and children.

\footnotetext{
${ }^{15}$ May, Homeward Bound, 57.

${ }^{16}$ Chafe, The American Woman, 217-8.

17 Stephanie Coontz, A Strange Stirring: The Feminine Mystique and American Women at the Dawn of the 1960s. (New York: Basic Books, 2011), 50.
} 
Another way that women could become "reacquainted" with their femininity was through fashion. The hallmark silhouette of postwar style, comprising a long full skirt and cinched waist, began in the world of high fashion, as part of the vision of designer Christian Dior. Dior named his 1946 collection the "Corelle Line," but it was so striking to Americans that Life magazine soon re-christened it "New Look."18 Along with its skirts and narrow waists, New Look was characterized by soft contouring around the bust and shoulders, or, in eveningwear, bare shoulders. The potentially sexually appealing nature of these form-fitting bodices was to an extent offset by the "modesty" provided by the full, long skirts that left the contours of the lower body a mystery to the viewer.

Dior would later elaborate on his inspiration for the New Look: "We were leaving a period of war, of uniforms, of soldier-women with shoulders like boxers....I turned [women] into flowers, with soft shoulders, blooming bosoms, waists slim as vine stems, and skirts opening up like blossoms." ${ }^{19}$ His comments suggest that the new fashion line was first off a response to the war's end and a celebration of plenitude after years of rationing. But it also follows that Dior felt that this time of peace invited a new (re-) conception of women as beautiful ornaments rather than functional social contributors.

From its appearance in high fashion spheres, the New Look was adapted and scaled for mass consumption. Karal Ann Marling suggests connections between the New Look and other postwar gender ideals. Marling suggests we might understand New Look fashions as physically constraining to women, providing a physical correlate to the social

\footnotetext{
${ }^{18}$ Karal Ann Marling, As Seen on TV: The Visual Culture of Everyday Life in the 1950s (Cambridge, Mass.: Harvard University Press, 1996), 10.

19 "Dictator by Demand," Time, March 4, 1957, 34, cited in Marling, As Seen on TV, 10.
} 
constraints women experienced in the postwar era, with "heels too high for walking, and dresses too confining for real freedom of movement." ${ }^{20}$ However, Marling notes, Dior conceived of the physical effects of his designs in very different terms: he imagined that in negotiating the heels, the billowy skirts and the tight bodices, women were taught by these outfits to discover a dancelike grace. ${ }^{21}$

A further way that the New Look style might have contributed to definitions of femininity was through the experiences and sensations the garments created for the wearer: "[women in New Look fashions] felt a constant pressure at the waistline, a flutter of drapery around the legs, the friction of flesh and close-fitting fabric across the breasts." ${ }^{22}$ In other words, the clothing did not only serve to reinforce gender differences to the observer by accentuating womanly curves; the clothes could also make women feel more feminine along the lines of white, middle class femininity of the era.

\section{Page's poise}

Through fashion, physique and demeanor, Page reflected many aspects of idealized placid femininity. While it was standard for female postwar pop singers to perform publicly in formal attire, Page quickly became known for an especially feminine presentation. She embraced the New Look wholeheartedly, regularly appearing in its hallmark gowns, and she drew attention in these outfits. In a 1950 concert review, Billboard notes that Page is "costumed in smart blue taffeta." 23 Washington Post theater critic Richard Coe describes Page in one concert as wearing "a dress of blue ostrich

\footnotetext{
${ }^{20}$ Marling, As Seen as TV, 16.

${ }^{21}$ Marling, As Seen as TV, 11.

${ }^{22}$ Marling, As Seen on TV, 16.

23 "Vaudeville Reviews: Chicago," Billboard, May 6, 1950.
} 
features" 24 and in another as "done up in enough filmy, glistening white to clothe 50 wedding processions." 25 A Chicago Tribune interviewer notes that Page has $\$ 50,000$ of clothes in the "roomy closets" of her New York apartment. ${ }^{26}$

That wardrobe was indeed very important to Page is evident in her autobiography when she recounts how she would change dresses four or more times per episode of her television show The Big Record:

It meant a lot of extra work outside the studio, just over my outfits. I'd go to stores like Saks or Bergdorf Goodman to look at gowns. A designer would go down into the garment district and bring other selections back to my apartment or to the studio for fittings. There was a different wardrobe lady at the studio for the day of the show. Of course, I just loved it. When you are young, everything is exciting and wonderful, but the clothes and costumes were a real treat. ${ }^{27}$

When asked recently about her own participation in developing her luxuriant, feminine style, Page said, "I guess I was the one responsible for that, without knowing it. I worked with designers and costumers for certain shows, off and on, but it was mostly my own doing., 28

Whether or not her embrace of New Look fashions structured Page's physical movement and bearing in the ways that Dior had hoped his fashions would, Page exuded

\footnotetext{
${ }^{24}$ Richard L. Coe, "One on the Aisle: Miss Pattie Page Hums and Hogcalls," The Washington Post, November 8, 1952.

${ }^{25}$ Coe, "One on the Aisle: When Patti Booms That Word 'Love'," The Washington Post, March 16, 1951.

${ }^{26}$ Steven Scheuer, “An Hour with Patti," Chicago Tribune, June 23, 1956.

${ }^{27}$ Patti Page, This Is My Song: A Memoir (Bath, NH: Kathdan Books, 2009), 106.

${ }^{28}$ David Nick Ybarra, "Patti Page: Record of a Legend, Journey of a Woman," Daeida Magazine, November 2010.
} 
a physical poise and grace that registered with audiences. A Life article from 1951 features of photo of Page with her arm extended in front of her as if she were blowing a kiss, or acknowledging her audience before curtseying. The caption reads: "Singing Patti has a radiant smile and friendly gestures which bring down the house in her personal appearances. ${ }^{, 29}$ In a 1951 concert review, Richard Coe is impressed by Page's movement (or lack of it): “As to poise, Queen Mary would have nothing to teach her.” A year later, Coe remarks on Page's stillness in performance: "Physically she finds it necessary to move scarcely an eyebrow or a feature."30

We can see examples of Page's graceful movement in her television performances. In song after song, her "choreography" consists of slow and careful steps if she moves across stage at all. She makes slow and floating arm gestures, and she often looks into the distance rather than at the camera as if she were in lost in a dream. Her gentle movements are accentuated by the gauzy fabrics of her full dresses and chiffon scarves, as in, for example, her 1956 televised performance of "Tennessee Waltz." For this number, the camera starts on Page in a medium close-up. She is glamorously coiffed and made up, wearing a formal New Look gown in a satiny fabric. The skirt seems composed of several billowy layers and is cinched with a wide belt. As the camera pulls back we see that Page has retreated outdoors from a ballroom. A chandelier is visible, as are couples dancing through a gauze-covered window. Page proceeds to slowly peel off her long satin gloves as the unseen orchestra introduces "Tennessee Waltz" at a tempo more languorous than the 1950 single version. Page turns away from the camera, and

\footnotetext{
29 "Patti's Platters: Railroad Man's Daughter Sells 5 Million," Life, May 21, 1951.

${ }^{30}$ Coe, "One on the Aisle: Miss Pattie Page Hums and Hogcalls," November 8, 1952.
} 
takes slow, gliding steps to the music's beat. She sits down on a bench under a tree, and faces the camera to sing. Her full skirt fans out around her, and she folds her hands in her laps to sing. Her upper body, flattered in a form-fitting bodice, remains still, and open with the upper body posture of a dancer. She sings the entire song from this posture, conveying wistfulness through her voice and feminine poise through her body. ${ }^{31}$

Even when Page performs more upbeat numbers on television, the combination of her movement, her attire and the context of those around her makes her look still and poised as opposed to energetic and spirited. For example, in her 1958 performance of "With You On My Mind" a moderately fast rhythm number, Page enters the stage by descending a staircase, wearing a New Look gown and carrying a long chiffon scarf. Despite the heavily accented beat and brassy orchestration of the musical number, Page descends the stairs gently, eliding rather than accenting the groove. At several points during the song Page snaps her fingers or sways very gently to the beat. These actions require little overall movement, and allow her to retain her upright, airy posture. It is the mixed-gender chorus of dancers whose movement matches the vitality of the musical groove. The chorus of dancers-singers enters the stage and proceeds to perform around Page while Page herself remains relatively poised and still. ${ }^{32}$

Page's image presented more than physical attributes of placid postwar femininity. Although Page was not a wife or mother until after 1960, she nevertheless conveyed idealized maternal and spousal qualities. In interviews and press pieces Page expressed the same kind of self-sacrifice that was encouraged in wives and mothers, but

\footnotetext{
31 Patti Page, “Tennessee Waltz," Staged Television Performance, Songalongs, 1956.

${ }^{32}$ Patti Page, "With You On My Mind," Staged Television Performance, The Big Record, 1958.
} 
instead of subordinating herself to her family, Page was deferential to her listening public. As early as 1952 Page tells an interviewer that she leads only a "public life," with her schedule allowing no time for a private life. ${ }^{33}$ Four years later she tells a New York Times writer she has never had more than two weeks off since her career took off. ${ }^{34}$ This same Times writer opens his piece on a note of approval about Page's bodily selfdiscipline: "Weighing in at 115 pounds - which is 25 pounds less than a few months ago - a refreshingly slim Patti Page is delighting television audiences this summer." 35 To attain this pleasing appearance, Page reports that she has slimmed down "by just not eating."

Along with the idea of self-sacrifice, Page's persona exuded the sense that she cared about her audiences, in the same way that mothers and wives were expected to meet the needs of their family. Page considers her adolescent fans in a guest column of the Chicago Tribune:

I rely very much on the teen-agers for advice myself, because they always have good sense. I always look forward to getting their opinions on any new records I have released. Altho [sic] my latest release, "Allegheny Moon," is still rather new, I'm looking forward to hearing from your readers as to how they like it. ${ }^{36}$

The deferential, doting language Page uses presents the persona of a mother concerned that she has done all she can to please and comfort her family.

\footnotetext{
${ }^{33}$ Lydia Lane, "Patti Page Found to Be Really 'Girl Next Door'," Los Angeles Times, May 11, 1952.

${ }^{34}$ Scheuer, "An Hour with Patti," 1956.

${ }^{35}$ Scheuer, "An Hour with Patti," 1956.

${ }^{36}$ Patti Page, "Patti Page Likes New Record Page," Chicago Tribune, June 9, 1956.
} 
Page also presented an attitude of deference and subordination with respect to her career. Despite her success, she often appeared to interviewers to be unaffected, even self-doubting, rather than exuding confidence, assertiveness or self-importance. For example, columnist Lydia Lane notes that success has "not gone to [Page's] head," which is good, Lane adds, because "nothing spoils beauty faster than conceit." Lane reports further on her conversation with Page:

"I've been lucky," Patti said with appreciation for her Cinderella story, "but I've had to work extra hard because I was accepted as a professional years before I felt I was one myself." ${ }^{37}$

Page's self-assessment here is so rife with self-deprecation as nearly to fold on itself: she attributes her success to "luck," thereby discounting her own role in her success. But then she admits that she has worked very hard, suggesting that her success is at least in part due to her own actions. However, she then attributes her motivation to work hard to a lack of self-confidence.

To the New York Times writer who asks how Page copes with her demanding television schedule, Page replies, "it's easy... I just do things people tell me to do." 38 Here, Page preemptively corrects a mistaken notion that she is an assertive or demanding presence on the television set. She implicitly assures readers that she is not a "diva." Instead, her remarks suggest, she accepts her role as a deferential performer, just as many American women were urged to accept their roles as supportive, subordinate wives and mothers.

\footnotetext{
${ }^{37}$ Lane, "Patti Page Found to Be Really 'Girl Next Door'," 1952.

${ }^{38}$ Scheuer, "An Hour with Patti," 1956.
} 


\section{Hearing Page historically}

Listeners who today hear Page's recordings as primarily placid are not completely disconnected from what historical commentators heard. The theme in Page's historical reception corresponding most nearly to "placidity" is that of "warmth." For example, Billboard writes of "All My Love," that it is "sung with warmth and persuasion,"39 and about "Once in a While" that Page is "singing in her usual warm style." " Fred Reynolds of the Chicago Tribune says of "Tennessee Waltz" that it a "wistful tune that fits Patti's warm style to a fur-lined mitten."

Additional themes, however, appear in Page's reception as often or more frequently as that of "warmth." (See table 1.5.) In particular, historical writers often commented on Page's vocal power, her distinctiveness and her versatility. As early as 1949, music writers for Billboard are struck with the power of Page's voice. One critic writes of a live show in 1949 that Page's “canarying power lies in easy delivery, sock voice control, sales savvy and a faculty for hitting each note right on the noggin. Lass shouts and carols 'em with equal skill and she's big league with the sultry species, too." Her hit "Would I Love You" is called "strong" and "virtuosic."43 "Mockin' Bird Hill" is deemed a "smash job,"44 "Mister and Mississippi is a "superb, intimate job" and a "super performance. $" 45$

\footnotetext{
${ }^{39}$ Billboard, July 29, 1950, 118.

${ }^{40}$ Billboard, June 28, 1952, 38.

${ }^{41}$ Fred Reynolds, "Platter Chatter," Chicago Tribune, November 27, 1950.

${ }^{42}$ Billboard, June 18, 1949. A note on Billboard jargon: this trade publication is replete with "hip," "insider" language. Here are some translations: "Canarying" is one of many synonyms for (female) singing. "Sock": powerful. "Sales savvy": persuasion, commitment. "Carols": sings ballads.

${ }^{43}$ Billboard, January 13, 1951.

${ }^{44}$ Billboard, February 20, 1951.

${ }^{45}$ Billboard, May 12, 1951.
} 
Generally, these positive reviews do not yield details about the kind of power the writers hear in Page's performance - are commentators struck by Page's vocal tone, by impressions of loudness or breath control? The review for "Come What May" is a bit more specific. Billboard describes it as "a simple, appealing ballad....sung with super projection." ${ }^{46}$ The term "projection" provides clues about power. In the Billboard context, "projection" might be used to designate a voice that sounds "loud" and "strong" - a voice that would carry well in a live venue. ${ }^{47}$ And yet, "Come What May," is one of Page's more gently delivered songs. The reviewer may instead be pointing to Page's unwavering delivery, long lines and clear enunciation. Regardless of how exactly "projection" is being used here, the writer is commenting at least to some extent on technical proficiency.

As well as noting her vocal power, reviewers often make of note of Page's versatility. During an era when a significant degree of versatility is expected from pop singers, Page stands out for being especially versatile. Some of Page's earliest reviews describe her in terms that suggest critics see her as simply "fitting in" with the recent trend of big band female singers transitioning to solo singing: as one writer says, "she has a "tear-in-her-voice" quality and "poignant appeal" 48 (meaning she sings moving ballads) and her style is "jazzappealwise." $"$ These comments suggest Page is at first heard in

\footnotetext{
${ }^{46}$ Billboard, January 19, 1952, 38.

${ }^{47}$ Jonathan Ross Greenberg, "Singing Up Close: Voice, Language, and Race in American Popular Music, 1925-1935" (PhD diss., University of California, Los Angeles, 2008), 52. Greenberg argues that listeners of recordings "hear the physical effort required to sing loudly, whether that effort is "necessary" or not." In other words, the volume of sound (the intensity) emitted by two singers over a playback device may be comparable (if measured in decibels) but a listener will still intuit which of the two is singing more loudly.

${ }^{48}$ Billboard, review of "I've Got Some Forgetting to Do," 1947.

${ }^{49}$ Billboard, review of "Goody Goodbye," 1947.
} 
terms of the evolving tradition of a "girl singer" for a big band.

But Page's ability to sing in a heavier vocal style is noted from early in her career when she is deemed a "fine blues singer" $" 50$ in 1947; she is said to give a "race-flavored piping" to a song in $1948^{51}$; and she shows a "strong blues feeling on some pleasant lyrics" on the record "With My Eyes Wide Open" and its B-side "Oklahoma Blues., The reviews of some recordings are explicit in connecting her singing to " $\mathrm{r} \& \mathrm{~b}$ " style (rhythm and blues.) For example, her recording of "What Dream," is deemed a "bluesy opus sung beautifully." 53 And "Come What May" is described as "a simple, appealing ballad sung with super projection in Patti's splendid, r\&b affected style with organ and vocal group backing.",54

Billboard also notes that Page's versatility extends to her ability to sing country songs in convincing style: so, for the song "Money, Marbles and Chalk," "Patti proves her versatility by handling this Western song with full folk feeling and making it just as acceptable for pop buyers." ${ }^{, 55}$ And Page is praised for her cover of the country song "Detour": "Patti does a forthright job of reviving a country hit item of some years ago. Should do particularly well in the c\&w market, where Patti has a following."56

As well as pointing to Page's success with adopting the performance stylings suited to non-mainstream pop (r\&b, country), some critics comment on a more general versatility in performance: "She's become a polished entertainer and has learned to set a

\footnotetext{
${ }^{50}$ Billboard, May 24, 1947.

${ }^{51}$ Billboard, September 18, 1948, 31.

${ }^{52}$ Billboard, December 24, 1949, 32.

${ }^{53}$ Billboard, July 17, 1954, 52.

${ }^{54}$ Billboard, January 19, 1952, 38.

${ }^{55}$ Billboard, March 5, 1949, 104.

${ }^{56}$ Billboard, July 28, 1951, 35.
} 
mood, with her rhythm numbers giving an entirely different treatment from the extra saccharine job she gave 'Tennessee Waltz." ${ }^{, 57}$ In a review for "Ever True, Evermore," Billboard welcomes the return of Page's "great beat for a crisp reading of a classic set in a rhythmic frame." Billboard further commends her with the statement, "Good change-up effort for the thrush." ${ }^{58}$ By 1954, Page's versatility is a truism. The review of "What a Dream" states, "Patti can sing any type of tune and sing it with feeling.,"59

Finally, the theme that appears most frequently around Page's singing involves her “uniqueness.” In a 1950 Billboard piece, Johnny Sippel comments on Page's recordings and her "unusual delivery that's building with every release." ${ }^{60}$ In 1952 , the phrases "her own powerful style" and "her inimitable style" are used to describe Page's singing. ${ }^{61}$ In 1954 , the idea of her uniqueness is accepted as fact, according to reviews which carry pronouncements like "She sings it as only she can," the song "'I Cried' is sold as only Patti can." 62

To call a singer "unique" is in one sense to state the obvious, since no two singers are exactly alike. The question, then, is why writers return to this descriptor when it comes to Page's singing in ways they do not for other singers. Two surprising reviews from Washington Post critic Richard Coe help to shed light on this issue. Coe was the regular theatre critic for the Post from 1946 until 1981. While popular music was not his beat, he reviewed hundreds of live musical performances over his tenure there and

\footnotetext{
${ }^{57}$ Billboard, January 20, 1951, 34.

${ }^{58}$ Billboard, April 21, 1951, 87.

${ }^{59}$ Billboard, July 17, 1954, 52.

${ }^{60}$ Johnny Sippel, "Vaudeville Reviews, Billboard May 6, 1950, 49.

${ }^{61}$ Billboard, August 16, 1952, 46; Billboard, November 15, 1952.

${ }^{62}$ Billboard, January 30, 1954; Billboard, July 17, 1954, 52.
} 
showed an appreciation for commercially successful acts with middlebrow appeal. He was a well-respected and well-liked reviewer. ${ }^{63}$

In his column "One on the Aisle," Coe published two remarkable reviews of Patti Page: first in 1951 and then 1952. These two pieces constitute the most detailed historical impressions of Page's voice and delivery. Coe's language is far from the pat, repetitive or “hip-jargon" language of Billboard, but is instead very idiosyncratic and colorful.

In his March 1951 piece, "When Patti Booms that Word 'Love,"' Coe reviews Page in a pre-film performance. ${ }^{64}$ After describing Page's appearance in highly flattering terms, Coe then describes her voice. He prefaces this section with the statement, "Since the sound of her pipes is patently well known, there's little need to describe her voice..." which is unfortunate from the present perspective of a historian! Nevertheless, Coe does proceed with this strange but suggestive passage:

The word "Love" appears in all of Miss Patti's songs and the cannonade sound she manages to give it — a sort of rich, Nelson Eddy sincerity — is clearly one of her stocks in trade. Other ladies in her trade approach, but never quite achieve, the tortured anguish she booms into the word. Surrounding syllables may be be whispered or given the delicate, Margaret Truman touch, but, if only by sheer contrast with her rivals, Miss Patti gives that chanted word the soul-reaching emotion of a rhinoceros

\footnotetext{
${ }^{63}$ Gerald Bordman and Thomas S. Hischak, "Coe, Richard L[ivingstone]," The Oxford Companion to American Theatre (Oxford University Press, 2004.)

${ }^{64}$ A common engagement for postwar pop singers involved performing a musical set preceding the showing of a Hollywood feature film.
} 
under a cold shower. Add to this a Southern accent and you'll find Miss Patti is unique and understandably a wow. ${ }^{65}$

Late the following year, Coe again devotes his column to Page:

What matters in Miss Page's repertoire is her ability to bring to single words or single syllables volumes of meaning: she can split that abrupt word "when" into a thousand parts, each falling physically into the muscles and sinews of her hearers. If she seems to embark on a lullaby tone for the beginning of some one-syllable word like "I," you could get odds that it will wind up an unashamed hog call. While this approach has been Miss Page's from her almost remote jukebox queendom, as indeed it is Johnny Ray's, there has come into it a refinement, even a subtlety, that is downright impressive. Her gamut is like a combination of honey and mercury. ${ }^{66}$

Taken together, these two reviews by Richard Coe showcase the fanciful writing style of their author. They are also potentially offensive: few women, if any, would appreciate being compared to a rhinoceros (either in shape or in sound), and neither would a postwar pop singer who strives for vocal smoothness want her singing to sound like a "hog call." However, Coe's descriptions need to be contextualized within the complete articles. The reviews are laden with flattering remarks: Coe praises Page's beauty and poise, and he also uses complimentary terms for her voice: "cannonade sound" and "lullaby tone." He compares Page to Nelson Eddy and Margaret Truman, two classically-trained singers

\footnotetext{
${ }^{65}$ Coe, "When Patti Booms that Word Love," Washington Post, March 16, 1951.

${ }^{66}$ Coe, "Miss Patti Page Hums and Hogcalls," Washington Post, November 8, 1952.
} 
who achieved mass appeal in film and on radio. Furthermore, given Coe's reputation as a warm and knowledgeable critic, there is no reason to suspect he is being ironic or backhanded. Rather, it appears that Coe is trying to get at the ways that Page is more than just a beautiful singer with a beautiful, classical-like voice.

The comparisons to male singers Nelson Eddy and Johnny Ray further suggest that Page conveys a power and vocal depth that Coe associates more readily with male rather than singers. What's more, the evocation of these two very contrasting male stars suggests the gamut Coe hears in Page's voice. ${ }^{67}$ Nelson Eddy's classical baritone was polished and pure, whereas Johnnie Ray shocked audiences with his unbridled vocal anguish, and rock historians often cite Ray's vocal style as an early influence in rock and roll singing. ${ }^{68}$

Another important aspect of Coe's assessment of Page is that he considers her performances in terms of the smallest unit of pronunciation and delivery: that of a single word, even a single syllable. In the first review, Coe meditates on Page's pronunciation of the word "love," and in the second review, Coe notes that her melodic delivery of the word "I" can be a kind of journey. This suggests that Coe heard Page's voice as affecting listeners, at least in part, on the level of "sound" over "song." That is, whereas some singers create more of an impression by stamping their personality on a song, telling a

${ }^{67}$ Also for the Washington Post, Coe had reviewed Johnny Ray in performance in March 1952. Coe's review of Ray bears similarities in tone to the potentially offensive and assuredly strange pieces on Page. Yet as with his pieces on Page, Coe's review of Ray is ultimately glowing. While Coe describes Ray's performance in almost animalistic terms - Ray "writhes around" and "closes his eyes and screws up his face"- Coe concludes that "the effect is sensational....By the time the curtains staggered closed on the nearly disintegrated performer I was all on his side." Washington Post, March 28, 1952.

${ }^{68}$ See, for example, James Miller, Flowers in the Dustbin: The Rise of Rock and Roll 1947-1977, (New York: Simon \& Schuster, 1999), 72. Miller connects Elvis Presley to Frankie Laine and Johnnie Ray, "two white singers of the era who had launched their pop careers with emotive recordings that sounded so authentically "black" that both men were briefly bona fide black music stars." 
story, or projecting “themselves" Page's vocal tone, and her articulation of individual words and melodic notes invites listeners to lose themselves in "pure" vocal sound. As a whole, the historical commentary on Page's singing suggest that in her own time, Page's performances were heard as warm, but that she was also perceived as a powerful singer, who was notable for her flexibility across styles, and her seeming ability to sing "anything." Moreover, many writers circle around the idea that there is something "unique" in Page's voice. Considered on its own, the descriptor "unique" is not very helpful. However, in parsing some of the longer reviews written by newspaper Richard Coe, we can surmise that the uniqueness, the "inimitable style" of Page is due not only to her flexibility across styles, but to the fact that whether she is honing a more "beautiful" vocal style, or a more "forceful" one, that she does so with richness and power.

\section{"She can sing anything"}

The idea that Page was a powerful singer may have been reinforced by the fact that she was perceived as versatile. To some extent, this was a requirement of postwar pop singers: Alban Zak has noted how the mainstream pop music industry of the 1950s was marked by a "search for the new." While in the 1930s and 1940s, pop singers sang mostly Tin Pan Alley songs in swing arrangements, in the 1950s, major labels were constantly seeking out new varieties of song material for their vocal stars. ${ }^{69}$ Both Zak and Elijah Wald have shown how record executives and producers became more interested in the potential for producing pop "crossover" records: having pop singers record songs that

\footnotetext{
${ }^{69}$ Albin Zak, I Don't Sound Like Nobody: Remaking Music in 1950s America (Ann Arbor, Mich: University of Michigan Press, 2010), 46.
} 
have shown success on either country charts or rhythm and blues charts. ${ }^{70}$

However, even in the context of postwar pop's "normative versatility," Page's output was diversified. This is in part because Page was so comfortable in a variety of styles. As a teenager, Page had sung on radio for both pop music and country music programs. Other formative experiences included weekly a capella hymn singing in church, and close harmony singing with her sisters, both for fun and professionally as short-lived radio act. ${ }^{71}$

In one sense, all of Page's hits are "pop" hits because they were created for the pop market. However, we can divide Page's hits into styles based on a combination of the following factors: how the records were described by industry writers; the qualities of the song compositions; the songwriters' backgrounds; the existence of recordings preceding Page's versions; and what kind of arrangement and performance Page and her musicians gave the songs. (See tables 3.3 and 3.4.)

Figure 1.1 contrasts the style distribution of Page's top hit singles with those of Doris Day and Mary Ford/Les Paul. The Ford/Paul duo was unusual in their commitment to their unique rhythm-country blend and guitar-based instrumentation. However Day was a more typical postwar pop act in terms of style output, and while she covered all the same styles as Page, her output is not as diversified as Page's. In particular, Day is lacking in the Latin and country categories.

\footnotetext{
${ }^{70}$ Zak, "Chapter 4: Crossing Over," in I Don't Sound Like Nobody; Elijah Wald, How the Beatles Destroyed Rock " $n$ " Roll: An Alternative History of American Popular Music (Oxford University Press, 2009), 159-165.

${ }^{71}$ Page, This is My Song, 15-16, 22-24;
} 
TABLE 3.3 Style of Page's 34 top-charting singles

\begin{tabular}{|c|c|c|}
\hline Year & Song & Style \\
\hline 1948 & Confess & Rhythm ballad \\
\hline 1949 & So In Love & Latin \\
\hline 1950 & With My Eyes Wide Open & Sweet ballad \\
\hline 1950 & I Don't Care if the Sun Don't Shine & Rhythm uptempo \\
\hline 1950 & All My Love & Latin \\
\hline 1950 & Tennessee Waltz & Country \\
\hline 1951 & Would I Love You & Latin \\
\hline 1951 & Mockin' Bird Hill & Country \\
\hline 1951 & Down the Trail of Achin' Hearts & Country \\
\hline 1951 & Mister and Mississippi & Country \\
\hline 1951 & Detour & Country \\
\hline 1951 & And So to Sleep Again & Sweet ballad \\
\hline 1952 & Come What May & Rhythm ballad \\
\hline 1952 & Whispering Winds & Sweet ballad \\
\hline 1952 & Once in a While & Sweet ballad \\
\hline 1952 & You Belong to Me & Sweet ballad \\
\hline 1952 & I Went to Your Wedding & Country \\
\hline 1952 & Why Don't You Believe Me & Sweet ballad \\
\hline 1952 & Conquest & Latin \\
\hline 1953 & Doggie in the Window & Novelty \\
\hline 1953 & Butterflies & Novelty \\
\hline 1953 & This is My Song & Sweet ballad \\
\hline 1953 & Changing Partners & Country \\
\hline 1954 & Cross Over the Bridge & Rhythm moderate \\
\hline 1954 & Steam Heat & Novelty \\
\hline 1954 & What a Dream & Rhythm ballad \\
\hline 1954 & I Cried & Rhythm ballad \\
\hline 1954 & The Mama Doll Song & Novelty \\
\hline 1954 & Let Me Go Lover & Country \\
\hline 1956 & Go On With the Wedding & Country \\
\hline 1956 & Allegheny Moon & Sweet ballad \\
\hline 1956 & Mama From the Train & Sweet ballad \\
\hline 1957 & Old Cape Cod & Sweet ballad \\
\hline 1957 & Left Right Out of Your Heart & Novelty \\
\hline
\end{tabular}

TABLE 3.4 Style of Page's 34 top-charting singles: count and proportion

\begin{tabular}{|l|r|r|}
\hline \multicolumn{1}{|c|}{ Style } & Count & \multicolumn{1}{c|}{ Proportion (\%) } \\
\hline Country & 9 & 26 \\
\hline Sweet & 9 & 26 \\
\hline Rhythm & 6 & 18 \\
\hline Novelty & 6 & 18 \\
\hline Latin & 4 & 12 \\
\hline
\end{tabular}




\section{Sonic House of Mirrors}

While Page's style diversification impressed reviewers with her versatility, the historical perception of her records as unique and powerful was surely in part attributable to their frequent use of mulitracking. Les Paul and Mary Ford would also use the technique extensively on their records, creating multitudes of textural voice-guitar combinations. In contrast, Page used the technique only for vocal overdubbing, and nearly always to create "self-harmony": block chord textured vocals containing between two and four separate musical lines.

This facet of Page's hit output is striking today. While the practice of overdubbing voices continues to the present, it is now used more subtly, usually to enrich or add depth to a lead vocal. Today, overdubbed vocal tracks are not usually incorporated to suggest a distinct vocal presence in addition to the lead. Page's records, on the other hand, purposefully project the illusion that two, three or four simultaneous iterations of "Patti Page" are singing at the same time.

"Confess" was Page's first song to break into the Billboard charts, and it uses multitracking to emulate call and response. ${ }^{72}$ Billboard's description of the newly released record shows that the "gimmick" stood out to reviewers, but not necessarily captivated them. The review states, "An unspecified thrush does an echo chamber obbligato in back of Patti's vocal. Sounds like Patti might have dubbed it in herself."73

\footnotetext{
${ }^{72}$ The record was released during the same week as a competing version on Columbia: a duet by Doris Day and Buddy Clark.

${ }^{73}$ Billboard, May 22, 1948, 125. While it does not appear in this review, the term "gimmick" is often used to describe multitracking in the records of Page and Les Paul/Mary Ford. Billboard's postwar use of this term seems neutral rather than pejorative, though I cannot rule out the idea that it conveys a certain
} 


\section{FIGURE 3.1 Excerpt of "Confess" showing call and response overdubbing}

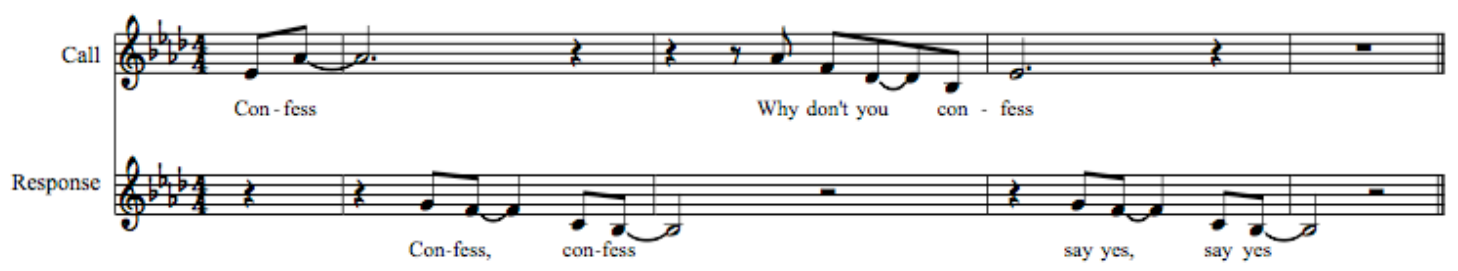

However, most of Page's multi-tracked records involve block chord harmony.

The first of its kind in her output is "With My Eyes Wide Open." In her memoir, Page describes the challenges in recording four-part harmony with herself.

The process was quite an education. You see, I was used to three-part harmonies, which are simple. If you're doing a three-part harmony, it sounds good as soon as you put the second harmony on, and the third one just fits in. When it's four parts, it's a different thing altogether because in the third part you sing notes that you wouldn't ordinarily and the full sound doesn't come together until you add the fourth voice. If you make a mistake on the third voice, you might not hear it until you try to add the fourth. The whole thing didn't sound natural until I added the fourth part. ${ }^{74}$

The feat was not just technological. ${ }^{75}$ It required skill and concentration on Page's part.

Since she could not read music, she learned all four parts as individual lines. The fourth

ambivalence.

${ }_{74}^{74}$ Patti Page, This Is My Song: A Memoir (Bath, NH: Kathdan Books, 2009), 43.

75 In her account of the "Confess" recording session, Page says that is was her idea to do record with herself, and that her engineer Bill Putnam "somehow figured out the technical details." Page, This is My Song, 36-37. 
part and its "notes you wouldn't ordinarily" sing refers to the sixths and sevenths coloring close-harmony triads, pitches that are not always intuitive to connect into individual lines, especially on their own. It was a technical feat for Page to learn and perform the densely packed vocal lines with steady intonation.

Whether or not audiences could know or intuit the labor involved in Page's multitracked records, they may have been beguiled by these records that emulated those of close harmony groups, but presented a novel level of blend and "sameness" between voices. "With My Eyes Wide Open," was Page's follow-up hit to "Confess," and reached number 11 on the charts. The record impressed Billboard reviewers, who said, "Patti sings all voices in the Quartet here. It's a fine feat musically, and the blend, of course, is great, as is the old tune. Jocks should favor this one for its unusual gimmick."76

Close harmony singing was popular in Page's time. Many vocal groups, male and female, attained commercial success through the 1930s and 1940s, including the Boswell Sisters, The Andrews Sisters, the Ink Spots, and the Mills Brothers. Before Page's family settled in Tulsa, they spent time in Wichita, Kansas, during which Page was a neighbor to the Dinning family_-from which hailed the singing group the Dinning Sisters. There is nothing to suggest that Page sang with or directly learned from the Dinning Sisters trio. But any close proximity Page had to them and their singing would have simply added to her experience of close harmony singing. In fact, Page drew inspiration for "With My Eyes Wide Open" by hearing the tune performed by a vocal group with whom she shared the stage for an extended resort gig:

$\overline{{ }^{76} \text { Billboard, December 24, 1949, } 32 .}$ 
I would sit and listen to them. They did such neat songs, they were a pleasure to hear! I loved the song and told Jack [Rael, Page's manager] I should record it, although I meant to do only one voice on it. Jack liked the idea but the more we talked about it, we realized it just lent itself to four voices, so why shouldn't I do all four? ${ }^{77}$

In her memoir, Page notes how she formed a trio with two of her sisters in seventh grade. "For months, we were regulars on a [radio] show with a fantastic guitar player, doing the Pop songs of the day."78 Singing with her sisters, formally or informally, was something Page continued to do through early adolescence: "Since my sisters and I loved to sing, we'd just sit out on the porch or in the swing and sing our hearts out doing mostly Pop songs we learned from song sheets in Song Hits magazine. The boys would come to listen, and the girls, too. It was just people enjoying the music, but nothing big because the town was no more than 100 people or so.",79

And while Page's church singing experience might not have taught her harmony, it gave her a chance to observe and practice the art of vocal blend:

The Church of Christ was a regular Christian church, like the Methodist or Baptist churches, and there was a lot of singing of hymns. The big difference was that there was no musical accompaniment. I always thought it was interesting that I grew up attending a church where there were no musical instruments played during the service. None of the churches we attended had a choir. The hymn was started with a little pitch

\footnotetext{
${ }^{77}$ Page, This is My Song, 42.

${ }^{78}$ Page, This is My Song, 16.

${ }^{79}$ Page, This is My Song, 16.
} 
pipe blown by the singing leader. We sang from hymnals like most other Christian churches. There was an emphasis on not being showy and fitting in with the congregation, which might be why, even when I was becoming well known as a singer on the radio in high school, no one ever asked me to sing a solo at church. ${ }^{80}$

The blend Page achieves in multitracked self-harmony may owe something to her church experience of "not being showy."

Page's execution of self-harmony in "With My Eyes Wide Open" is notable not only for its intonation, but for her ability to blend the different timbres of her voice. (These will be discussed in detail below.) Page uses relaxed pop singing for the lower notes while she belts the higher notes. The top melody of this song starts with a held note of B b 4 going down to A4. This is above Page's normal break and so her chest voice at this range is necessarily an intense and brassy belt. As we will discuss below, Page rarely uses belt style for an entire song, and when she does it is for uptempo numbers. "With My Eyes Wide Open," is a sweet ballad and would not be suitable for Page's belt voice from beginning to end were she singing solo. However, the mellow lower voices attenuate the higher belted notes throughout this song. So, while the top voice sounds brash in its upper range, the lower voices remain in comfortable relaxed-pop territory and thus they round out the sound. This kind of blend involves Page knowing well her own voice and its capabilities, and Page and her producers knowing instinctively what combinations of vocal timbres and ranges blend palatably.

\footnotetext{
${ }^{80}$ Page, This is My Song, 15.
} 
Page's copious use of multitracking is one of the aspects that can deter modern listeners from her records. ${ }^{81}$ Even the Billboard writers were ambivalent about it, referring to it as a "gimmick." Other pop singers did use the technique occasionally_ For example, Rosemary Clooney uses a similar call-response to "Confess" in her song "Hey There," and Kay Starr uses two-part harmony in the chorus of her hit "Wheel of Fortune." But it was a technique that Page and her producers enjoyed or felt compelled to repeat again and again.

Tables 3.7-3.9 show the distribution of vocal textures across Page's top hit singles. Half of Page's hit records present Page's overdubbed voice for at least a portion of the song. Yet it is also notable that of the songs that feature overdubbing, all but one feature at least some solo singing. (The only exception is “Tennessee Waltz.”) A pattern repeated across many hit songs is one where Page sings the verse solo, and then a Page duo, trio or quartet sings the refrain.

It need not have been the sheer novelty of the technology that drew listeners - it may also have been Page's mastery of the technique, because Page executed the technique so well, in matching phrasing between vocal parts, and in blending different vocal timbres to complement each other across a given pitch range.

${ }^{81}$ Friedwald, for example, decries the extensive use of multitracking in Page's output. In contrast, he notes, "on the very few [records] where she has good songs, good charts, and doesn't use multitracking, Patti Page flies in a very high orbit." Friedwald, "Patti Page," 362. 
FIGURE 3.2 Excerpt of “With My Eyes Wide Open” showing overdubbed 4-part harmony

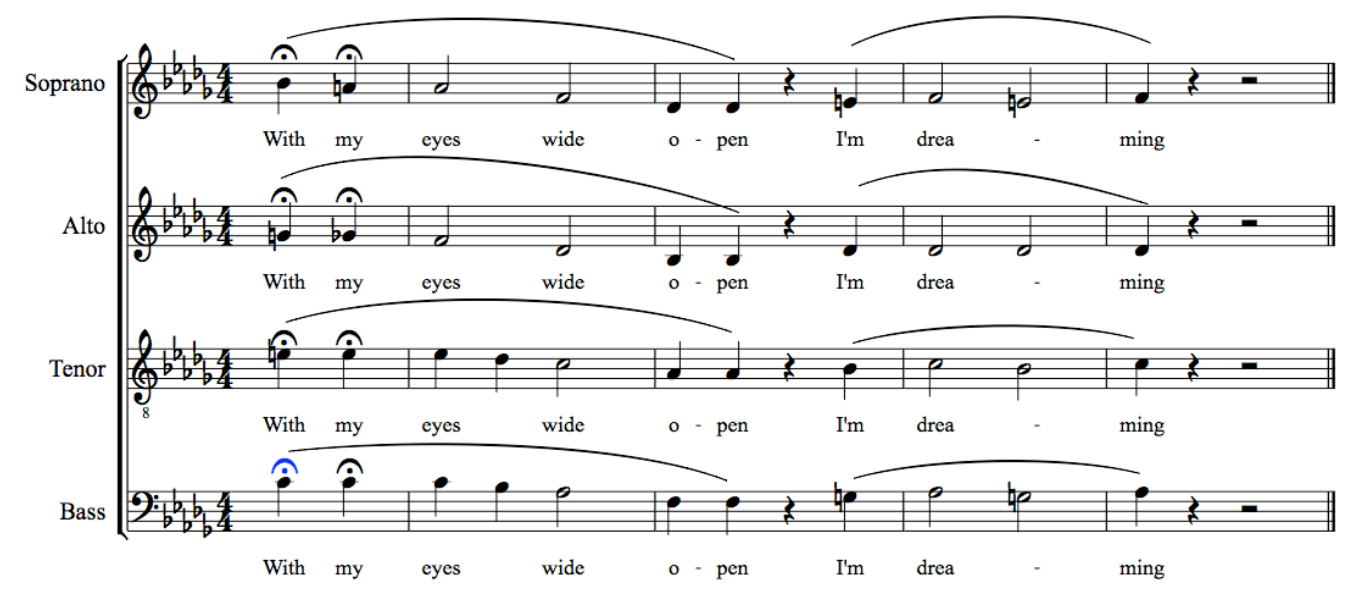

TABLE 3.5 Vocal textures on Page's 34 top-charting singles: descriptions, codes

\begin{tabular}{|l|r|}
\hline \multicolumn{1}{|c|}{ Vocal texture type } & Code \\
\hline Solo throughout & $\mathrm{SV}$ \\
\hline Overdubbing throughout & $\mathrm{S}+\mathrm{OV}$ \\
\hline Solo plus overdubbing & $\mathrm{S}+\mathrm{CH}$ \\
\hline Solo with (other voices) chorus & $\mathrm{S}+\mathrm{OV}+\mathrm{CH}$ \\
\hline Solo plus overdubbing with chorus & \\
\hline
\end{tabular}

TABLE 3.6 Vocal texture on Page's 34 top-charting singles

\begin{tabular}{|r|l|l|}
\hline \multicolumn{1}{|c|}{ Year } & \multicolumn{1}{|c|}{ Song } & Vocal texture \\
\hline 1948 & Confess & S+OV (counterpoint) \\
\hline 1949 & So In Love & S+CH \\
\hline 1950 & With My Eyes Wide Open & S $+\mathrm{OV}$ \\
\hline 1950 & I Don't Care if the Sun Don't Shine & S \\
\hline 1950 & All My Love & S \\
\hline 1950 & Tennessee Waltz & OV \\
\hline 1951 & Would I Love You & S \\
\hline 1951 & Mockin' Bird Hill & $\mathrm{S}+\mathrm{OV}$ \\
\hline 1951 & Down the Trail of Achin' Hearts & $\mathrm{S}+\mathrm{OV}$ \\
\hline 1951 & Mister and Mississippi & $\mathrm{S}+\mathrm{OV}$ \\
\hline 1951 & Detour & $\mathrm{S}+\mathrm{OV}$ \\
\hline 1951 & And So to Sleep Again & $\mathrm{S}+\mathrm{OV}$ \\
\hline 1952 & Come What May & $\mathrm{S}+\mathrm{CH}$ \\
\hline 1952 & Whispering Winds & $\mathrm{S}+\mathrm{OV}$ \\
\hline 1952 & Once in a While & $\mathrm{S}+\mathrm{OV}$ \\
\hline 1952 & You Belong to Me & $\mathrm{S}$ \\
\hline 1952 & I Went to Your Wedding & $\mathrm{S}$ \\
\hline
\end{tabular}




\begin{tabular}{|r|l|l|}
\hline \multicolumn{1}{|c|}{ Year } & \multicolumn{1}{|c|}{ Song } & Vocal texture \\
\hline 1952 & Why Don't You Believe Me & $\mathrm{S}+\mathrm{CH}$ \\
\hline 1952 & Conquest & $\mathrm{S}+\mathrm{OV}$ \\
\hline 1953 & Doggie in the Window & $\mathrm{S}+\mathrm{OV}$ \\
\hline 1953 & Butterflies & $\mathrm{S}+\mathrm{OV}$ \\
\hline 1953 & This is My Song & $\mathrm{S}$ \\
\hline 1953 & Changing Partners & $\mathrm{S}$ \\
\hline 1954 & Cross Over the Bridge & $\mathrm{S}+\mathrm{OV}$ \\
\hline 1954 & Steam Heat & $\mathrm{S}+\mathrm{OV}$ \\
\hline 1954 & What a Dream & $\mathrm{S}+\mathrm{CH}$ \\
\hline 1954 & Cried & $\mathrm{S}$ \\
\hline 1954 & The Mama Doll Song & $\mathrm{S}$ \\
\hline 1954 & Let Me Go Lover & $\mathrm{S}+\mathrm{CH}$ \\
\hline 1956 & Go On With the Wedding & $\mathrm{S}$ \\
\hline 1956 & Allegheny Moon & $\mathrm{S}+\mathrm{CH}$ \\
\hline 1956 & Mama From the Train & $\mathrm{S}+\mathrm{OV}+\mathrm{CH}$ \\
\hline 1957 & Old Cape Cod & $\mathrm{S}+\mathrm{OV}+\mathrm{CH}$ \\
\hline 1957 & Left Right Out of Your Heart & $\mathrm{S}+\mathrm{CH}$ \\
\hline
\end{tabular}

TABLE 3.7 Vocal texture on Page's 34 top-charting singles: count and proportions

\begin{tabular}{|l|r|r|}
\hline \multicolumn{1}{|c|}{ Vocal texture code } & Count & Proportion (\%) \\
\hline Solo throughout & 10 & 29 \\
\hline Solo with (other voices) chorus & 7 & 21 \\
\hline Solo plus overdubbing & 14 & 41 \\
\hline Solo plus overdubbing with chorus & 2 & 6 \\
\hline Overdubbing throughout & 1 & 3 \\
\hline
\end{tabular}

\section{The Singing Rage}

The impressive versatility and the novel, vocal sound world Page offered through her records would not have drawn a sustained following if the quality of her singing was not also compelling. Discussion of Page's work rarely takes on a technical dimension, whether in historical or later writings, but it does not follow that her vocal appeal defies consideration on technical terms. In fact, close listening to her singing, along with comparisons to her contemporaries reveals several technical constants that help to explain 
her moniker "The Singing Rage."

Page, who rarely spoke about her technique or what was special about her vocal sound, did make at least one comment on her abilities, and it was in relation to her breath control. In a latter day interview in which she gently complains about the material she recorded in her heyday, Page says, "The same writer who wrote 'Doggie in the Window' wrote 'People' if you can imagine. That is a beautiful song that you can put some heart into. You're not thinking of holding a phrase for four bars in 'Doggie in the Window.' I doesn't matter if you do or not." ${ }^{\prime 82}$ The main point of Schoemer's inclusion of this quote in her essay is that Page, in the 1990s, wished she had had more repertoire given to her "that you can put some heart into." What is important here is that Page preferred material that allowed her to sing long phrases, for example ones of at least four bars, suggesting that her good breath control to have been important to her self-concept as a competent singer.

The ability to sing long lines is a necessity for classical singers. The best breath control (in coordination with the whole vocal apparatus) also allows the singer to change volume within a phrase - to go from loud to soft or soft to loud within a phrase without taking a new breath. While Page may not have had this mastery of breath management, she did compare favorably to other pop singers in this aspect of technique.

To show the relative ease of breath control Page has, we can consider Page's performance of songs that were recorded by other singers, comparing the breath management of key passages to see how Page presents better breath control in a similar

\footnotetext{
${ }^{82}$ Schoemer, "Patti," 28.
} 
melodic situation.

"You Belong to Me" was a song first introduced to the country market, and then covered by several pop singers. Jo Stafford had the biggest pop hit with the song. As was the practice then, Page and her label decided to record the song shortly thereafter.

Both Page and Stafford take "You Belong to Me" at a slow tempo, and generally breathe in the same places. For the line that starts the bridge section, "I'll be so alone without you," the text is stretched over four bars, making it 16 counts long, and showcasing the singer's ability to hold for this length. However, Stafford's line here is arguably less successful because the quality sounds strained compared to the rest of the song; Stafford anticipates the beat slightly in a way that does not sound like a rhythmically playful or adroit choice, but rather a response to faltering breath management; and Stafford's final note somewhat peters out. Whereas Page's phrase sounds within her control: the final last note does not trail off as Stafford's does; and Page's voice quality and phrasing is more consistent so that this section does not seem like a strain. ${ }^{83}$

Another opportunity for contrasting Page's singing with a contemporary's comes with the song, "Why Don't You Believe Me," most famously recorded by Joni James, but also a hit for Patti Page. The performances are taken at similar tempo and similar range. This ballad gives several opportunities for the singer to hold long lines, especially in the B section with the lyrics:

${ }^{83}$ Preceding both Page's and Stafford's recordings was the version by country singer Sue Thompson (Mercury 6407.) Thompson takes a similar tempo to Page's and Stafford's, but she makes no attempt to sing the line "I'll be so alone without you" without a break. She breathes after "alone," and to my ears this is a perfectly good decision. 
(B section)

Here is a heart that is lonely

Here is a heart you can take

Here is a heart for you only

That you can keep or break
(A section)
How else can I tell you
What more can I do

For the first three lines of B, Page and Jones breathe at the same place in the lyrics, though the exact length of time they hold their phrases differs, with Jones holding her note for a shorter length or equal length to Page each time:

TABLE 3.8 Breath control: comparison of Joni James and Patti Page in "Why Don't You Believe Me"

\begin{tabular}{|l|r|l|r|}
\hline \multicolumn{1}{|c|}{ James } & Duration (sec) & \multicolumn{1}{|c|}{ Page } & Duration (sec) \\
\hline Here is a heart that is lonely, & 5 & Here is a heart that is lonely, & 6 \\
\hline Here is a heart you can take, & 3 & Here is a heart you can take, & 5 \\
\hline Here is a heart for you only & 5 & Here is a heart for you only & 5 \\
\hline
\end{tabular}

However, in the next phrase we see a big difference in the breaths the two singers take. Jones sings: (breath represented by $\mid$ ):

That you can keep | or break |

How else can I tell you

Page sings through the end of B and moves into the new A section without taking a 
breath, and then sneaks a breath after "How else."

That you can keep or break (no breath $\rightarrow$ )

How else | can I tell you

Whereas James splits “That you can keep or break" into a 2-second and then a 4-second phrase, Page sings "That you can keep or break... How else" in one breath lasting for 9 seconds.

Deciding where to take breaths is informed by the combination of a pop singer's technical abilities and expressive intentions. James likely decided that a breath in the middle of the line "that you can keep or break" was a suitable choice given her abilities, whereas Page breathes through this line and into the next. Page may have thought this long line would sound more beautiful, or more impressive. When several singers recorded the same song around the same time artists and producers might have sought to find ways to put their own stamp on the song. Page's record came out after Joni James' version, and it is possible that Page and her producers sought to distinguish their record in particular by displaying Page's solid technique.

\section{Classical cannonade, measured belting}

There is no way to assuredly assign sonic characteristics to the aspects of Page's voice production and timbre that dominate her reception. However, there are ways to at least suggest possible correlates for Billboard's vaguer descriptions such as "unique," or "inimitable," or the more evocative descriptions of Coe, such as "cannonade sound" or “tortured anguish." Extensive listening to Page's output and comparison to that of her 
contemporaries helps to create a familiarity with her voice and a competence for distinguishing it from those contemporaries. In addition, observing spectrograms of Page's recordings can help to solidify or give descriptive power to audio observations. There are two ways in which spectograms yield helpful observations in listening to Page's records:

1. Noting the presence and extent of vibrato. A regular presence of vibrato, especially a vibrato that is relatively wide is a sign that the mode is relaxed pop singing. A tone with no vibrato (i.e. straight tone) is more likely a sign of belt.

2. Noting the presence and intensity of overtones. Titze is one of several voice scientists to suggests that female belting produces a strong second harmonic — in other words, the pitch one octave above the perceived pitch is of high energy (i.e., loud) in relation to the rest of the frequencies in the spectrum being projected. ${ }^{84}$ Often in the female belt voice, the energy of the octave overtone is higher than that of the fundamental. (Although we still hear the voice as singing the fundamental.) This very striking aspect of belting is sometimes visible in spectrograms of Page's records.

Extensivie listening and graphic visualization of Page's voice suggests that Page's singing can be grouped into two broad categories: relaxed and intense, which in turn correspond to the relaxed pop style and the belt style of singing. Relaxed pop singing is low-head voice predominant, and is characterized by a mellower tone, and prominent

\footnotetext{
${ }^{84}$ Ingo R Titze, Albert S. Worley, and Brad H. Story, "Source-Vocal Tract Interaction in Female Operatic Singing and Theater Belting," Journal of Singing - The Official Journal of the National Association of Teachers of Singing 67, no. 5 (May 2011): 561-572.
} 
vibrato. The belt style is brassier, shows little or no vibrato and is generally perceived as "louder." This categorization of Page's singing does not strongly distinguish her from her contemporaries: as discussed in Chapter 1, most postwar pop singers combined relaxed pop singing with some belt. What is different about Page is that the quality of her relaxed pop singing is almost classical; and her deployment of belt tone is often very measured and well integrated into passages of relaxed singing rather than standing out as jarringly brassy. These aspects of her approach to belt and relaxed pop are perhaps what draw comments like "unique." Her relaxed pop and her belt are more "refined" than in other singers.

Page's relaxed pop singing shares some features with classical singing. ${ }^{85}$ Although there is no single set of defining characteristics for classical singing, I present components that most vocal experts and pedagogues agree constitute classical vocal style: these include the ability to project (in volume) very loudly, without amplification; to sing long legato lines; to sing with a pleasing vibrato; to sing with a timbre that combines a dark rounded tone with a bright "ring," to transition smoothly up and down the pitch compass (sometimes called "equalizing registers"); and to possess vocal flexibility.

Another component of the classical singing style is a correlate of the technical demands. The technical requirements of classical singing favor the pronunciation of

${ }^{85}$ This discussion of classical singing components results from my engagement with dozens of articles authored variously by scientists, pedagogues and musicologists. Most helpful were pieces in which authors address both classical and popular singing styles. The most influential works to me are: Ingo R. Titze, “The Human Instrument," Scientific American, January 2008; Jeannette L. Lovetri, "Contemporary Commercial Music: More Than One Way to Use the Vocal Tract," Journal of Singing The Official Journal of the National Association of Teachers of Singing 58, no. 3 (January 2002): 249252; Laura Anne Bateman, "Soprano, Style and Voice Quality: Acoustic and Laryngographic Correlates" (Master of Arts Thesis, University of Victoria, 2003,) and Greenberg, "Singing Up Close." 
vowels that are "pure" (no diphthongs); and the vocal tract shaping that produces the classical style most readily involves a "north and south" mouth shape, and discourages a "smiley" mouth shape. As a result, applying classical technique to lyrics in English results in pronunciation that differs from most strains of American English speech. In fact, American English speakers who are unaccustomed to classical singing may find that hearing English sung by a classical singer is as hard to decipher as German or Italian.

Although Page never trained formally in classical singing (or in any style) she nevertheless possesses some technical abilities in common with classical singers, as shown in table 3.11. What she shares in common with classical technique most of all includes her ability to sing a long legato line, and her steady, wide vibrato. The main difference is that even when Page is in relaxed pop mode, her timbre and pronunciation depart from those of a classical singer. Compared to a classical singer, Page always chooses vocal tract and mouth shapes that allow for American English speech-like vowels.

Although it was never put in these terms, Page's ability to present some of the virtuosic qualities of classical singing into a popular context may have been both an attractive element of her voice, and a main distinguishing feature.

\section{TABLE 3.9 Elements of classical vocal technique applicable to Page's singing}

\begin{tabular}{|l|l|l|}
\hline $\begin{array}{c}\text { Aspects of } \\
\text { classical } \\
\text { technique }\end{array}$ & \multicolumn{1}{|c|}{ Description } & \multicolumn{1}{|c|}{ Applicability to Page's singing } \\
\hline Timbre & $\begin{array}{l}\text { Women singing with classical } \\
\text { technique produce a timbre that is } \\
\text { "darker" and "purer" than that of pop } \\
\text { singers. }\end{array}$ & $\begin{array}{l}\text { Page rarely if ever, is mistakable for a } \\
\text { classical singer. Granted her tone is more } \\
\text { pure, than many pop singers - she rarely } \\
\text { permits "noise" associated with huskiness } \\
\text { or strain into her voice. }\end{array}$ \\
\hline
\end{tabular}




\begin{tabular}{|c|c|c|}
\hline $\begin{array}{l}\text { Aspects of } \\
\text { classical } \\
\text { technique }\end{array}$ & Description & Applicability to Page's singing \\
\hline & & $\begin{array}{l}\text { But her vocal tract shaping creates a } \\
\text { brighter tone that of classical singers. }\end{array}$ \\
\hline Pronunciation & $\begin{array}{l}\text { Classical singers shape their vocal } \\
\text { tracts so that their mouths create a } \\
\text { "north-south" shape. This produces } \\
\text { vowel sounds that differ dramatically } \\
\text { from those of spoken American } \\
\text { English. Classical singers avoid } \\
\text { diphthongs. }\end{array}$ & $\begin{array}{l}\text { Page keeps more of an "east-west" shape } \\
\text { to her mouth, which allows vowel } \\
\text { pronunciation more akin to spoken } \\
\text { American English. Popular singers } \\
\text { pronounce diphthongs. }\end{array}$ \\
\hline $\begin{array}{l}\text { Equalization of } \\
\text { registers; } \\
\text { consistency of } \\
\text { tone }\end{array}$ & $\begin{array}{l}\text { As the female classical singer goes up } \\
\text { and down her pitch range, she avoids } \\
\text { stark or sudden changes in the timbral } \\
\text { profile, volume, and vibrato. }\end{array}$ & $\begin{array}{l}\text { When Page sings in relaxed pop style, her } \\
\text { equalization is not seamless; for example, } \\
\text { she tends pull back in volume as she } \\
\text { increases in pitch. But her vibrato profile } \\
\text { stays similar, so the effect is not jarring. }\end{array}$ \\
\hline Legato & $\begin{array}{l}\text { Classical singers learn to sing long lines } \\
\text { of music, with melodies that to } \\
\text { different pitches on different syllables } \\
\text { without. }\end{array}$ & $\begin{array}{l}\text { Page can sustain long lines, does so more } \\
\text { often than her peers, and appears to do so } \\
\text { with ease. }\end{array}$ \\
\hline $\begin{array}{l}\text { Volume/ } \\
\text { projection }\end{array}$ & $\begin{array}{l}\text { Traditionally, classical singing } \\
\text { technique allows the singer the ability } \\
\text { to produce enough volume to be } \\
\text { audible within a large venue above an } \\
\text { orchestra }\end{array}$ & $\begin{array}{l}\text { Page always performed with amplification. } \\
\text { Like most professional pop singers, she was } \\
\text { never expected to sing unmiked. However, } \\
\text { as listeners we still tend to judge whether } \\
\text { or not a singer "sounds loud" or "sounds } \\
\text { soft" in a recording. Page tends to pull back } \\
\text { - become softer - on her higher notes in } \\
\text { relaxed style. }\end{array}$ \\
\hline Vibrato & $\begin{array}{l}\text { A typically acceptable vibrato in } \\
\text { classical singing is nearly always } \\
\text { present (withheld only very judiciously } \\
\text { for certain emotional effects); it is } \\
\text { present nearly on onset, and it is } \\
\text { regular and consistent. }\end{array}$ & $\begin{array}{l}\text { Page's vibrato in relaxed mode is similar to } \\
\text { that of a classical singer, with the exception } \\
\text { that she often minimally delays the onset. }\end{array}$ \\
\hline
\end{tabular}

A good way to get an idea of the extent (and the limits) of Page as a classical singer is to compare her to a classical singer. And a good way to do this is to compare Page at her most "classical" to a classical singer at her most "popular."

Deanna Durbin was a "middlebrow soprano" popular in Hollywood musicals of 
the 1930s and 1940s. ${ }^{86}$ She was one of a handful of singing female film stars who sang with a classical style (Jeanette MacDonald was another) in film musicals with operetta leanings. Durbin's most famous performances and recordings showcase her classical soprano range: she sang easily in the C5-C6 octave, a full octave above the typical compass of a female pop singer. Many of Durbin's most famous recordings are English language versions of famous opera arias, for which there are no Page equivalents. However, Durbin did record some more popular repertoire and some of these songs unfold in a range that allows for a useful contrast with Page.

Durbin's recording of Irving Berlin's “Always” and Page's “This is My Song” are both moderate-tempo sweet ballads unfolding in comparable pitch ranges. (A b $3-\mathrm{B}$ b 4 for Page and B b 3-D b 5 for Durbin.) A comparison between them shows that even at her more "classical," Page's relaxed pop technique differs from classical style.

In “This is My Song," Page's vibrato is very prominent and regular, but it begins after a slight delay on most of her notes compared to Durbin's vibrato in "Always," which regularly occurs at onset. Page pronounces vowels with a more spoken-American quality, both in terms of the vowel colors, and the use of diphthong. Durbin takes some pronunciation liberties she would not if she were singing on the classical stage, but for the most part, she uses conventions of classical pronunciation.

The singers manage voice production across range differently. Durbin, who, as a classical singer, is well used to singing in her low and high head voices, has no trouble ascending the scale to her peak note of $\mathrm{D}$ b 5 - she does so while increasing volume.

\footnotetext{
${ }^{86}$ I was introduced to the term "middlebrow soprano" and to Deanna Durbin by Holley Repogle-Wong, "Mid-Century Hollywood Film Musicals and the Middlebrow Soprano," presented at the Society for American Music, $37^{\text {th }}$ Annual Conference, Cincinnati, Ohio, 2011.
} 
Whereas Page has to pull away from her top notes in order to sustain the relaxed low head technique, since she does not have a high head voice to move into.

However, there are also commonalities between these performances: both feature legato lines, both feature low head voice rather than chest voice, and both feature plentiful vibrato. While most listeners would not mistake Page for a classical singer of the Deanna Durbin variety, in records like "This is My Song” Page shows a kind of breath control, comfort in the low head voice vocal setting, relaxed sound and plentiful vibrato that we expect in classical singers, and these aspects all make Page stand out as a popular singer.

While Page's relaxed pop singing mode has elements of classical singing, she has an equally strong belt technique. However, she uses her belt voice judiciously, blending it in with her relaxed pop technique. She often reserves her belt voice for the song's climactic high point, and then resumes relaxed pop singing as she descends in pitch. This involves a good understanding of her own voice and capabilities, and working with arrangers who can coordinate melodic high points with Page's preferred melodic "money note" pitches of G4-A4.

Page's recording of "Spring is Here" demonstrates well her ability to blend relaxed pop and belt singing. For the most part, the song showcases Page in her very relaxed-pop quasi-classical style. (See figure 3.3.) However, Page shifts to belt technique for the ascending scale to project the climactic G4 with intensity. Her delivery remains very relaxed until the line "maybe it's because nobody needs me." The quality on "needs" becomes intense, suggesting Page is using her chest voice. The vibrato is late in 
onset and narrow when it unfolds, all of which suggest Page has shifted to belt technique.

One of the only examples of her using both techniques in a song, but using striking contrast rather than blend, is in her number one hit "I Went to Your Wedding." In this song, Page uses relaxed voice for the first sixteen measures, and then at the refrain, in which she leaps from a $\mathrm{C} 4$ to an $\mathrm{A} 4$, she shifts to belt technique. The timbre, the reduction in vibrato presence and the volume all contrast with what came before. This can also be seen very easily in a spectrogram. (See figures 3.4 and 3.5.)

Knowing how to differentiate Page's use of relaxed pop singing from belting, it is then possible to categorize the frequency with which she uses these two techniques exclusively or in combination. I have established five categories to cover the different ways Page combines belting and relaxed pop singing. (See table 3.15.) The five categories are Relaxed (R), Mostly Relaxed, (MR) Belt-Relaxed Mix (BR mix), Mostly Belt (MB), and Belt. (B.) I have also added optional descriptors: $+\mathrm{V}$ is added to songs in which she has a very prominent vibrato; and $+\mathrm{S}$ on songs in which she barely has any vibrato.

In the category "Relaxed" I have put songs in which Page never uses any belt that is, any pitches higher than G4 are sung in low head voice. These are Page's "gentlest" songs - they include "Tennessee Waltz" and "This is My Song." (See table 3.15.) On the other extreme are Page's songs that I categorize as Belt, i.e. songs that belted throughout: these are songs in which Page not only uses chest voice above G4, but also sings mostly in straight tone, through the whole song, and has a brassy quality to her voice throughout. I have marked only three songs in this category: "Conquest," "Cross 
Over the Bridge," and "Left Right Out of Your Heart." All three are uptempo numbers with an emphasis on rhythmic drive.

Most of Page's songs, however, include a mix of these two styles: as table 3.12 shows, about two-thirds of Page's songs show some kind of relaxed-belt mix (Mostly Relaxed; Mixed; or Mostly Belted.) Although Page does use belt in many songs, on the whole she uses relaxed singing slightly more often: if we compare relaxed/mostly relaxed to belt/mostly belt to mix, we get a breakdown of $60 \%-25 \%-15 \%$ respectively. Yet, at the same time, only one quarter of her hit songs are completely devoid of belt. Taken together, this breakdown shows an impressive distribution in Page's making use of both relaxed pop singing and belt.

Having surveyed these dimensions of Page's singing, it becomes possible to connect some of the press commentary and themes to actual qualities in Page's voice. The idea of her versatility makes sense when we look at the diversification across styles of her top hits, even within an era in which versatility was considered a requirement to be a pop singer. As to commentaries referring to Page's vocal power, a number of vocal qualities addressed above might explain this: the idea that Page holds long breaths, that she can sound very loud, and that nothing she sings seems beyond her or challenging her to her limits. In other words, commentators who describe Page's “power" are likely referring to Page's demonstration of "technique." And finally, Page's "uniqueness" is perhaps explained by her ability to combine aspects of classical technique - the very free vibrato and relaxed control of a classical singer-with popular styling. To audiences who had not heard much classical singing (or who would have found it off-putting) Page's 
singing in relaxed pop style would offer some of the beauty of classical singing not often found in pop singing - a very controlled but relaxed sound, the pleasing vibrato, the relatively purity of the tone, and the illusion of endless sound - but without the distortions of pronunciation or the unfamiliar language of classical music. Moreover, Page's ability to move in and out of belt with ease would also have been unique. Her training from her earliest years as a professional singer involved switching roles between country and pop singing. As a soloist she was then able to draw from this experience as she saw fit and the range it provided was unparalleled.

\section{FIGURE 3.3 "Spring is Here" excerpt}

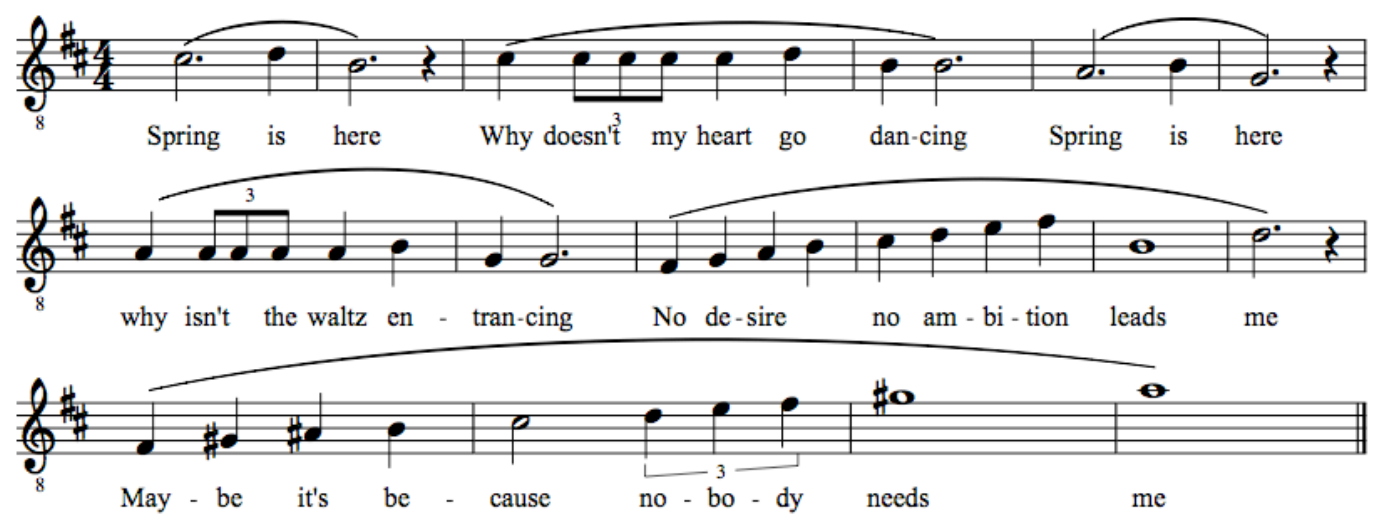


FIGURE 3.4 “I Went to Your Wedding” excerpt

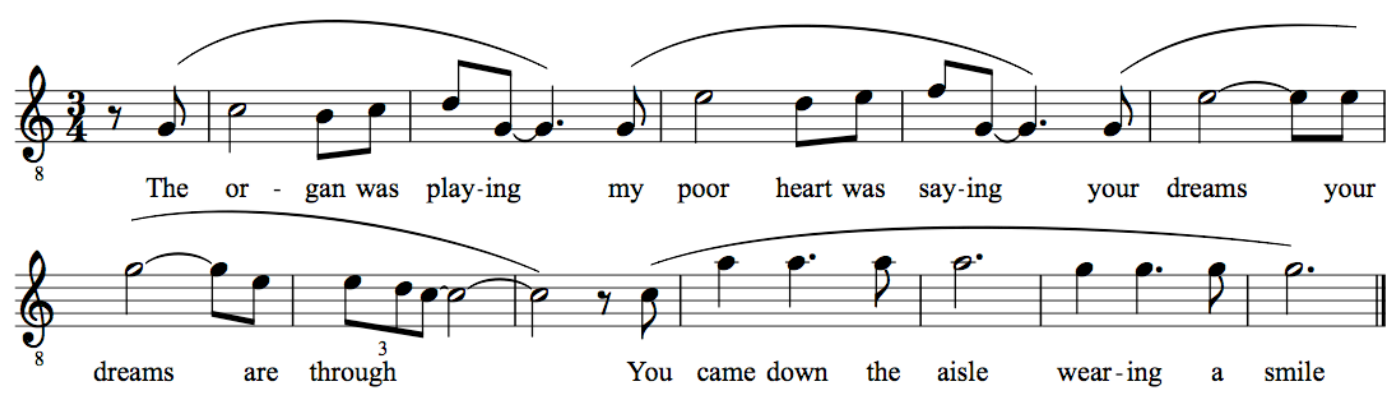

FIGURE 3.5 "I Went to Your Wedding" spectrogram showing shift to belt technique

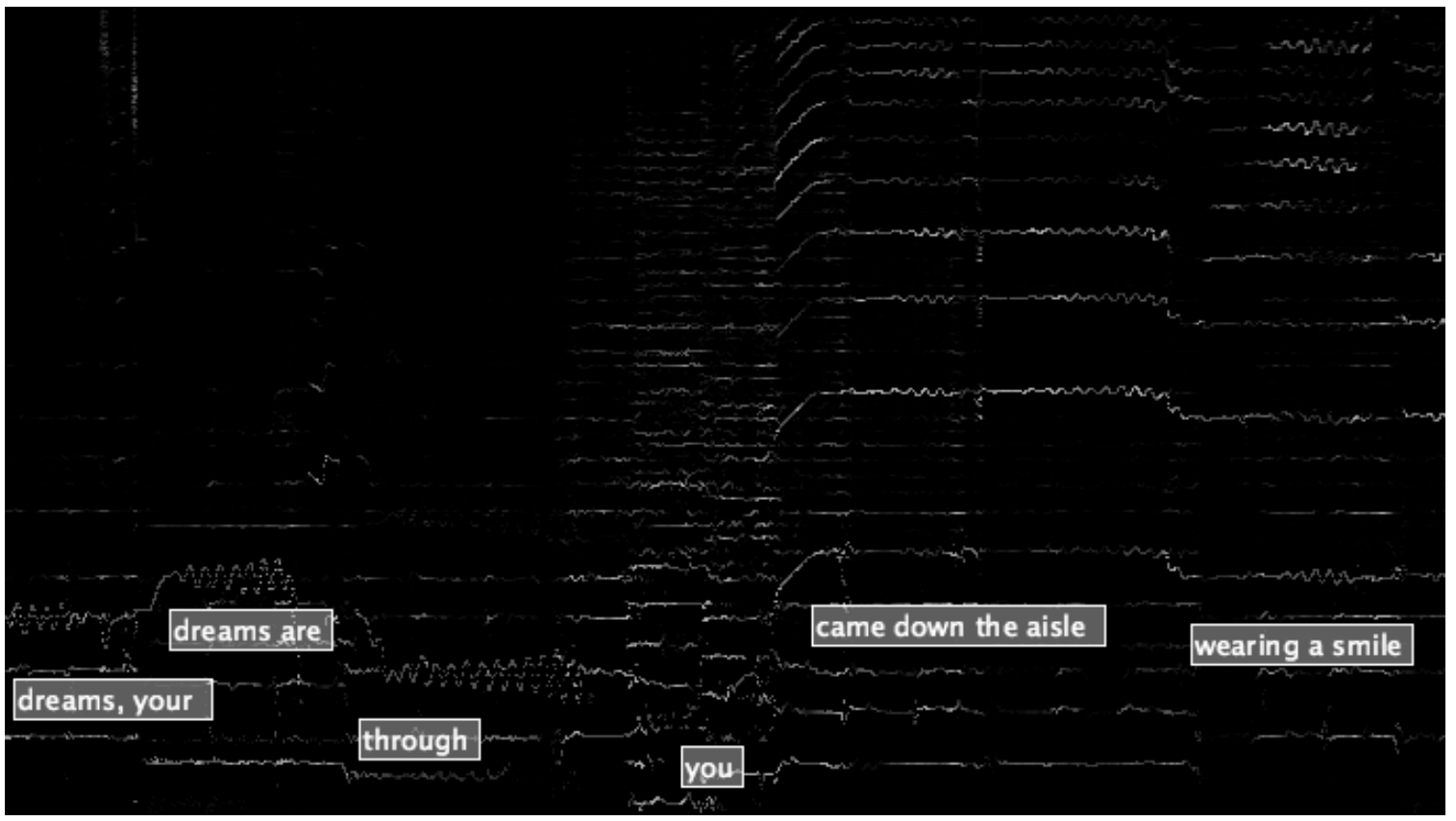

TABLE 3.10: Codes for Page's vocal style

\begin{tabular}{|l|l|}
\hline \multicolumn{1}{|c|}{ Abbreviation } & \multicolumn{1}{c|}{ Code } \\
\hline $\mathrm{R}$ & Relaxed \\
\hline $\mathrm{MR}$ & Mostly relaxed \\
\hline $\mathrm{B}$ & Belt \\
\hline $\mathrm{MB}$ & Mostly belt \\
\hline BR mix or contrast & Smoothly bridged belt/relaxed or contrast \\
\hline$+\mathrm{V}$ & + Prominent vibrato \\
\hline$+\mathrm{S}$ & + Straight tone \\
\hline
\end{tabular}


TABLE 3.11 Page's vocal style across recordings

\begin{tabular}{|c|c|c|}
\hline Year & Song & Vocal style \\
\hline 1948 & Confess & $\mathrm{MR}+\mathrm{V}$ \\
\hline 1949 & So In Love & $M R+V$ \\
\hline 1950 & With My Eyes Wide Open & $\mathrm{MB}$ \\
\hline 1950 & I Don't Care if the Sun Don't Shine & BR mix \\
\hline 1950 & All My Love & $\mathrm{MR}+\mathrm{V}$ \\
\hline 1950 & Tennessee Waltz & $\mathrm{R}$ \\
\hline 1951 & Would I Love You & $\mathrm{BR} \operatorname{mix}+\mathrm{V}$ \\
\hline 1951 & Mockin' Bird Hill & MR \\
\hline 1951 & Down the Trail of Achin' Hearts & MR \\
\hline 1951 & Mister and Mississippi & BR \\
\hline 1951 & Detour & MB \\
\hline 1951 & And So to Sleep Again & $\mathrm{MR}+\mathrm{V}$ \\
\hline 1952 & Come What May & $\mathrm{R}$ \\
\hline 1952 & Whispering Winds & MR \\
\hline 1952 & Once in a While & MB \\
\hline 1952 & You Belong to Me & $\mathrm{MR}+\mathrm{V}$ \\
\hline 1952 & I Went to Your Wedding & BR mix \\
\hline 1952 & Why Don't You Believe Me & $\mathrm{MR}+\mathrm{V}$ \\
\hline 1952 & Conquest & $B+S$ \\
\hline 1953 & Doggie in the Window & $\mathrm{R}$ \\
\hline 1953 & Butterflies & $\mathrm{R}$ \\
\hline 1953 & This is My Song & $R+V$ \\
\hline 1953 & Changing Partners & $R+V$ \\
\hline 1954 & Cross Over the Bridge & $B+S$ \\
\hline 1954 & Steam Heat & MB \\
\hline 1954 & What a Dream & $\mathrm{MB}$ \\
\hline 1954 & I Cried & MR \\
\hline 1954 & The Mama Doll Song & $M R+V$ \\
\hline 1954 & Let Me Go Lover & $B R \operatorname{mix}+V$ \\
\hline 1956 & Go On With the Wedding & MR \\
\hline 1956 & Allegheny Moon & $\mathrm{R}$ \\
\hline 1956 & Mama From the Train & $\mathrm{R}$ \\
\hline 1957 & Old Cape Cod & MR \\
\hline 1957 & Left Right Out of Your Heart & $B+S$ \\
\hline
\end{tabular}


TABLE 3.12 Distribution of vocal mode across Patti Page's top 34 hit singles

\begin{tabular}{|l|l|r|r|}
\hline \multicolumn{1}{|c|}{ Abbreviation } & \multicolumn{1}{c|}{ Code } & \multicolumn{1}{c|}{ Count } & Percent \\
\hline R & Relaxed & 8 & 23 \\
\hline MR & Mostly relaxed & 13 & 38 \\
\hline B & Belt & 3 & 9 \\
\hline MB & Mostly belt & 5 & 15 \\
\hline BR mix or contrast & Smoothly bridged belt/relaxed or contrast & 5 & 15 \\
\hline & TOTAL & $\mathbf{3 4}$ & $\mathbf{1 0 0 . 0 0 \%}$ \\
\hline
\end{tabular}

Page's placid image as it was projected in photos, on television and in interviews may have appealed to her audiences because it reflected the postwar ideal of "ultrafemininity." And yet, to restrict our understanding of Page's singing to an embodiment of a particularly passive postwar femininity occludes what in fact may have made her such a popular singer: her vocal power.

The historical reception surrounding Page's voice suggests that she pushed relaxed pop singing to its limits. And yet this is not an obvious conclusion to a presentday listener, because, since the advent of rock ' $n$ ' roll, "powerful” female pop singing signifies chest-register dominant voice production, with an intense, even strained quality as the singer approaches the limits of her range and volume. Whereas, Page channeled a classical-like technique into her popular singing: her rich tone, her steady vibrato, her impressive breath control, and her assured maneuvering across her range and between registers set her apart from her contemporaries. And, although Page's technique showed classical-like elements, she was a markedly different kind of singer from the middlebrow sopranos of the 1930s and 1940s. Page was through and through a pop singer. While she possessed some of the technical robustness of a classical singer, she was at home across diverse vernacular pop styles and could move in and out of belt technique with ease. Her 
nickname "The Singing Rage," arose as reviewers began to comment that she could "sing anything." Of course Page could not sing anything, but what is important is that she offered the possibility of a vocal omnipotence: to many listeners, her voice seemed infinitely capable, perhaps superhuman.

We cannot "unhear" the six decades of popular singing history that have shaped our present-day reactions to pop singers past and present. For this reason, when we listen to Page today, we must resign ourselves to the fact that we might never hear what the "Singing Rage" really sounded like. 


\section{Mary Ford: Unsung Talent, Interactive Muse}

When Les Paul died in 2009, his former wife and musical partner Mary Ford had been gone for over three decades, having passed away quietly in 1977 at the age of 53. She and Paul had divorced 13 years prior, ending a marital and professional partnership that had taken the early 1950s pop world by storm: between 1950 and 1955 they recorded a string of top-charting records, they toured and performed extensively in the US and abroad, and they hosted their own radio and television shows. (See tables 4.1-4.2.)

Although the duo is ranked as the fourth top selling pop act in the first half of the 1950s (see table 1.4), the music they made together was minimally discussed within tributes and written farewells in the wake of Les Paul's death. And in general, the PaulFord duo receives little attention either in tributes to Les Paul, or accounts of popular music history. It is true, though, that in the last two decades, Les Paul (as a solo entity) has enjoyed a resurgence of popularity and institutional recognition. Paul was inducted into the Rock and Roll Hall of Fame in 1988, and into the National Hall of Fame of Inventors in 2005; he was the subject of Chasing Sound!, a PBS American Masterworks documentary in 2007; and, he was awarded a National Medal of Honor in 2008. The tributes following Paul's death focused on his musical-technical contributions to popular music: specifically his innovations to the solid-body electric guitar, and his development of multi-track recording. These contributions of Paul's have been especially important and influential to guitar players, rock musicians, and producers and engineers.

Alongside institutional accolades and posthumous tributes, Paul has been the topic of some limited academic and general interest writing in the past two decades. The 
best source on his life is Les Paul, An American Original, a rigorously researched and well-sourced biography by Mary Shaughnessy. ${ }^{1}$ Not only does this volume provide a fairminded account of Paul's life, but Shaughnessy's chapters about Paul and Ford together comprise the only substantive biographical material on Ford. Thanks to interviews with Ford's surviving relatives and former colleagues, Shaughnessy is able to provide invaluable and otherwise undocumented details about Ford's childhood and early adulthood.

In Les Paul in his Own Words, Paul tells his own life story in a colorfully illustrated, glossy-paged coffee-table tome. While the work is no doubt valued by fans for its first-hand accounts and photographs, it has a rambling, repetitive quality. Paul's anecdotes can be simultaneously detailed and vague in a way that makes the book a challenging scholarly source. $^{2}$

On top of this coverage from journalistic and non-fiction spheres, there now exists some academic work on Les Paul. Serge Lacasse, Peter Doyle and Albin Zak have discussed the music of Les Paul and Mary Ford and its importance in being one of the first repertoires to use echo, reverb and overdubbing so effectively. ${ }^{3}$ These audiotechnical innovations help to explain the novelty and the enormous appeal the Ford/Paul

\footnotetext{
${ }^{1}$ Mary Alice Shaughnessy, Les Paul: An American Original, 1st ed. (New York: W. Morrow, 1993.) Unfortunately, Paul withdrew his support for Shaughnessy's book while her research was underway. She proceeded with its completion and publication nevertheless because she had already devoted considerable effort to it.

${ }^{2}$ Les Paul and Michael Cochran, Les Paul: In His Own Words (York Pa.: Gemstone Publishing, 2008.)

${ }^{3}$ Serge Lacasse, “'Listen to My Voice': The Evocative Power of Vocal Staging in Recorded Rock Music and Other Forms of Vocal Expression." (Ph.D. dissertation, University of Liverpool, 2000), 126-130; Peter Doyle, "From 'My Blue Heaven' to 'Race with the Devil': Echo, Reverb and (dis)ordered Space in Early Popular Music Recording," Popular Music 23, no. 1 (2004), 38-40; Albin Zak, I Don't Sound Like Nobody: Remaking Music in 1950s America (Ann Arbor, Mich: University of Michigan Press, 2010), 152, 157.
} 
duo presented to their audiences.

The most sustained scholarly analysis of the music of Les Paul and Mary Ford appears in Instruments of Desire, Steve Waksman's history of the electric guitar in popular music and its successive and varying associations with masculinity. ${ }^{4}$ Waksman devotes a fascinating and insightful chapter to Les Paul in which he describes Paul's search for "purity" in the electric guitar's tone. Waksman argues that this goal of achieving a "pure tone" related to Paul's wider goal of "domesticating" the electric guitar, stripping it from its more anarchic or brazen associations arising from connections with blues, jazz and hillbilly. Paul, Waksman argues, made the electric guitar domesticfriendly, that is, acceptable and attractive to a white middle-class pop audience. While Waksman's main focus is the electric guitar, in this chapter he accords considerable attention to the image that Ford and Paul projected as a couple, and provides an account of the way in which audio technology in the Paul-Ford home mediated their public and private relationship.

Waksman's chapter has been an inspiring antecedent for my work because of the thoughtful analysis of the gender dynamics at play in the couple's image. I pick up on Waksman's argument to suggest how gendered images of the couple might be audible in the records themselves. I further suggest how Ford's musical contributions to the partnership and the recorded output are crucial, yet seldom acknowledged. In this chapter, I show how Ford was not only a skilled vocalist, but an exceptional rhythm guitar player and a versatile musician with a keen musical ear and a wealth of

\footnotetext{
${ }^{4}$ Steve Waksman, "Pure Tones and Solid Bodies: Les Paul's New Sound," in Instruments of Desire: The Electric Guitar and the Shaping of Musical Experience (Cambridge, Mass.: Harvard University Press, 1999), 36-74.
} 
performance experience. She understood Les Paul's aesthetic and could keep up with his ambitious recording goals, facilitating his production of the records that made him so famous.

TABLE 4.1 Les Paul and Mary Ford: singles charting in top 20, 1950-1955

\begin{tabular}{|l|r|r|}
\hline \multicolumn{1}{|c|}{ Song } & Year & Top Chart Pos \\
\hline Tennessee Waltz & 1950 & 6 \\
\hline Mockin' Bird Hill* & 1951 & 2 \\
\hline How High the Moon & 1951 & 1 \\
\hline I Wish I Had Never Seen Sunshine & 1951 & 18 \\
\hline The World Is Waiting for the Sunrise & 1951 & 2 \\
\hline Just One More Chance & 1951 & 5 \\
\hline Tiger Rag & 1952 & 2 \\
\hline I'm Confessing & 1952 & 13 \\
\hline In the Good Ol' Summertime & 1952 & 15 \\
\hline Smoke Rings & 1952 & 14 \\
\hline Take Me In Your Arms & 1952 & 15 \\
\hline My Baby's Comin' Home & 1952 & 7 \\
\hline Bye Bye Blues & 1952 & 5 \\
\hline I'm Sitting On Top of the World & 1953 & 10 \\
\hline Johnny is the Boy For Me & 1953 & 15 \\
\hline Vaya Con Dios* & 1953 & 1 \\
\hline Doncha Hear Them Bells & 1953 & 13 \\
\hline I Really Don't Wanna Know & 1954 & 11 \\
\hline I'm a Fool To Care & 1954 & 6 \\
\hline Wither Thou Goest & 1954 & 10 \\
\hline Hummingbird & 1955 & 7 \\
\hline
\end{tabular}

Source: Whitburn 2001, Whitburn 2002.

TABLE 4.2 Les Paul and Mary Ford: radio and television programs

\begin{tabular}{|c|l|}
\hline Year(s) & \multicolumn{1}{c|}{ Program } \\
\hline $1949-1950$ & $\begin{array}{l}\text { The Les Paul Show with Mary Ford, NBC Radio, } \\
\text { 15-minute radio show broadcast from Los Angeles Station KFI, Friday nights. 23 episodes. }\end{array}$ \\
\hline 1953 & $\begin{array}{l}\text { Les Paul and Mary Ford at Home, Syndicated Television Show, } \\
\text { Filmed at the couple's Mahwah, New Jersey home. Five-minute show broadcast daily. } \\
\text { Sponsored by Listerine. 170 episodes. }\end{array}$ \\
\hline
\end{tabular}

\section{Musical girl, professional teen, soft-shell country singer}

Although it was not until partnering with Les Paul that Mary Ford became a nationally known performer, she had shown a passion and skill for music since 
childhood, and constantly impressed her family members, teachers and coworkers with her musical talent. By the time she met Les Paul in 1945, the 21-year old Ford held multiple years of performance experience.

Née Colleen Summers, Ford was born in 1924 in Pasadena, California, the third of seven children to a Nazarene minister father. Both of Ford's parents were musical, and all of the siblings learned to play and sing at a young age. Ford's mother taught her seven-year old daughter guitar chords, and Ford's sister would later recall how Mary used to sneak her older brother's guitar out to play it whenever he left the house. ${ }^{5}$

By her teens, Ford was performing regularly with her family and with her own trio. Her father spearheaded a weekly religious radio show in which the whole family played and sang between his preaching sessions. Outside of the performances with her family, Ford formed a group with her neighbors, brother and sister Milly and Marvin Watson. This trio would perform whenever they could in churches across Pasadena. Milly and Mary won a talent contest in $1939 .^{6}$

For a year during high school, Ford's parents sent her to the small town of El Centro, in hopes that she would focus more on her studies. Although Ford was unhappy being so far from the rest of her family, she there benefitted from a music teacher who gave her guitar lessons and encouraged her to perform in concerts and in contests, one of which she won. ${ }^{7}$

Ford returned to Pasadena after this year away, and convinced her parents to let her give up school in favor of a music career in Los Angeles. By 1942, Ford secured the

\footnotetext{
${ }^{5}$ Shaughnessy, Les Paul, 147.

${ }^{6}$ Shaughnessy, Les Paul, 148.

${ }^{7}$ Shaughnessy, Les Paul, 148.
} 
first of several regular spots performing on Los Angeles country radio, starting with a show hosted by country artist Cliffie Stone. Ford's performing relationship with Stone extended to live gigs all around Los Angeles as well as to the radio show Hollywood Barn Dance, a program comparable to Nashville's Grand Ole Opry and Chicago’s National Barn Dance. Ford's last professional accomplishment before joining Les Paul was as a singer with Gene Autry on his Melody Range radio show.

When Ford partnered with Les Paul to make pop music, all of her performance experience to that point had been in country and white gospel spheres. And yet, Ford's vocal style would prove easily adaptable to mainstream popular music. In his book on country music, Richard Peterson recounts how there is a continually evolving, dialectical relationship between two country substyles, which he calls hard-core and soft shell. ${ }^{8}$ Hard core country singers tend to feature some or all of the following traits: "untrained voice with nasal tone," "rough harmonies," "raw emotion," southern or Southwestern accent, southernism in speech, white southern grammar. ${ }^{9}$ In contrast, soft shell singers tend to showcase "trained voice with full tone, smooth harmonies," "songs sung, not emoted," "singers interpret experiences and feelings of the songwriter in a way that they may be shared by all listeners," "standard American grammar, "relatively unaccented or having a melodious regional accent with all the hard edges extracted."10

The LA radio artists Ford had performed with were all on the soft shell side of the

\footnotetext{
${ }^{8}$ Richard A. Peterson, Creating Country Music: Fabricating Authenticity (Chicago: University of Chicago Press, 1997), 138.

${ }^{9}$ Peterson, Creating Country Music, 151.

${ }^{10}$ Peterson, Creating Country Music, 151. Although I take his meaning, I disagree with Peterson's use of the term "trained voice" since few country singers of either of Peterson's types receive institutional "training." However, I agree with what I think he wishes to communicate: that soft shell country singers have smoother pop voices.
} 
country divide Peterson describes. For example, Ford sang backup for Jimmy Wakely on the CBS network's Hollywood Barn Dance. Heard on recordings like “One Has My Name” and "I Love You So Much It Hurts Me," Wakely's voice is rich, has a regular, even vibrato, and he projects relaxation rather than tension in his singing. Wakely's soft shell country style is further evidenced in that one of his biggest hits was a duet with pop singer Margaret Whiting. The pair's “Slippin' Around” was a number 1 hit on both the country and mainstream pop charts. The vocal blend that Whiting achieves with Wakely on this record would not have been possible with a hard core country singer like Hank Williams or Ray Acuff.

The fact that Ford always worked with soft shell country colleagues like Wakely would have encouraged her to develop a soft shell vocal style of her own. One of the few existing recordings of Ford's pre-Les Paul singing, "I Wonder Where You Are Tonight," confirms this. ${ }^{11}$ Ford's soft, pop-friendly approach to country vocals on this song is particularly obvious compared to a recording by Kitty Wells, a female postwar country singer whom Peterson deems hard-core. On her hit "It Wasn't God Who Made Honky Tonk Angels," (1952) Wells' voice is nasal, sounding tense and strained, and it evinces a rapid, irregular vibrato. This strained quality does not indicate a vocal flaw in Wells' technique but rather a specific aesthetic. On "I Wonder Where You Are Tonight," Ford is certainly identifiable as a country rather than a pop singer: her voice is brighter and more nasal than it would be for most of her pop music records with Les Paul. She also sings

\footnotetext{
${ }^{11} \mathrm{I}$ became aware of this recording through an Internet search, and have been able to stream it, but have not been able to obtain it through more traditional or official means. The best information I have been able to glean about the recording suggests that it is a radio transcription of a late 1940s performance by Ford's group the Sunshine Girls, a vocal trio that accompanied Jimmy Wakely on radio, on television and on some recordings.
} 
with a stronger southern accent than she would for her pop hits, for example, pronouncing "tonight" as "tonahht." However, unlike the hard core Wells, Ford performs with a steady vocal tone, and her slower-rate vibrato suggests a more relaxed voice production.

\section{Ford's pop-country technique}

Ford and Paul met in 1945 when Paul was seeking a female vocalist for his hillbilly radio show. This meeting came at a crossroads for Paul: he had been a professional musician since 1929, first playing in hillbilly circles, and then living a dual musical life alternating between country and jazz ensembles. Alongside his performing, he cultivated an interest in sound technology that would eventually lead him to his major contributions to development of the solid-bodied electric guitar and multi-track recording. By 1945, he was losing interest in the direction jazz was taking, and was contemplating how he might enter the more lucrative and audience-accessible pop music market. $^{12}$

Paul hired Ford for a hillbilly radio stint, one of many gigs that tided him over financially as he contemplated how to penetrate the mainstream pop music market. This particular radio gig was short-lived, but the occasion sparked the beginning of the Paul/ Ford relationship. Despite Paul's appreciation of Ford's singing, he did not initially think her a suitable vocalist to partner with him in his quest to create the mainstream pop records. Shaughnessy recounts that, "although he loved the lush sound of Mary's voice, he had pigeon-holed her as a "hillbilly singer, a lightweight." He wanted a vocalist with

\footnotetext{
${ }^{12}$ Shaughnessy, Les Paul, 136.
} 
more vibrato, more guts. .... In any case, he finally decided to give it a whirl with [Mary.]"13

On the Paul/Ford recordings, Ford sings differently depending on song style and vocal texture. (See table 4.3). In ballads, Ford's voice is usually featured as a solo singer and she uses a relaxed, or mostly relaxed voice for these songs. The uptempo numbers tend to present a multi-tracked Ford singing in block-chord harmony with herself. In these choral configurations, Ford usually blends different vocal timbres across voices, often singing the principal melodic line with a brighter, and sometimes belted quality. The vocal texture and vocal quality on the duo's waltzes lie between these extremes.

When Ford's voice is perceptible as a solo voice, she shares several characteristics of other postwar pop singers. Her relaxed style sounds smooth and unstrained, and she pronounces words clearly. A quality that sets her relaxed singing apart, though, is her tendency to work in the lowest section of her vocal range with a very breathy tone on some of her ballads.

Ford's pitch range, as heard across all the top-charting recordings she produced with Paul, is very low for a female pop singer. (See table 4.4) On average, Ford sings a half tone lower than Patti Page and a whole tone lower than Doris Day. Even more striking is the extent to which Ford reserves her lowest-pitched singing for ballads. Compared to her overall pitch range, Ford sings ballads across a compass that dips a whole tone lower than her average, and that peak a perfect fourth below her overall average melodic peak. These low ballads tend to unfold in the octave between E3 and E4,

\footnotetext{
${ }^{13}$ Shaughnessy, Les Paul, 170.
} 
and convey a sensuous, relaxed tone.

It is on these low-pitched ballads that Ford's singing is further rendered unique among contemporaries through Paul's recording practices. Due to Paul's preference for close miking, on these slower numbers, Ford's voice sounds as if she were singing mere inches from the listener. In addition to this recording technique, Paul often further enhances the sound of Ford's voice through the addition of echo or reverb. Nearly all of the top 21 singles display some amount of reverb or echo applied to Ford's voice. The effect, when pronounced, can result in the surreal sound of "I'm Confessin'," but when used more subtly serves to add pleasing warmth to Ford's vocal performances.

TABLE 4.3 Summary of vocal textures and Ford's voice quality across top singles according to song style

\begin{tabular}{|l|l|l|}
\hline Style/tempo & \multicolumn{1}{|c|}{ Dominant Vocal texture } & Dominant or most prominent voice quality \\
\hline Ballad & $\begin{array}{l}\text { Solo or solo with limited block chord } \\
\text { harmony with wordless backing (i.e. } \\
\text { "ooh," "ahh.") }\end{array}$ & $\begin{array}{l}\text { Relaxed or mostly relaxed; often soft and } \\
\text { breathy }\end{array}$ \\
\hline Uptempo & $\begin{array}{l}\text { Block chord harmony throughout or } \\
\text { nearly throughout }\end{array}$ & $\begin{array}{l}\text { Mostly belted; dominant voice usually more } \\
\text { nasal and with straight tone }\end{array}$ \\
\hline $\begin{array}{l}\text { Waltz/ } \\
\text { midtempo }\end{array}$ & $\begin{array}{l}\text { Solo or solo with up to half block } \\
\text { harmony or wordless backing }\end{array}$ & Combination of belt and relaxed \\
\hline
\end{tabular}

TABLE 4.4 Average singing ranges on 4 highest charting singles by Ford, Page and Day

\begin{tabular}{|l|l|l|}
\hline \multicolumn{1}{|c|}{ Mary Ford } & \multicolumn{1}{|c|}{ Patti Page } & \multicolumn{1}{c|}{ Doris Day } \\
\hline How High the Moon & Tennessee Waltz & Love Somebody \\
E3-E4, top voice belts A4 & F3- C5 & A3-B4 \\
\hline $\begin{array}{l}\text { The World is Waiting for the Sunrise } \\
\text { A b3- B4 }\end{array}$ & Mockin Bird Hill & It's Magic \\
\hline Tiger Rag & G3 to A b4 & F3-B $b 4$ \\
Top pitch D5 & I Went to Your & Again \\
\hline Vaya Con Dios & G3 to A4 & B b3-B4 \\
E3-F4 & Doggie in the Window & Secret Love \\
\hline Average range: & G3 B4 & F\#3-B4 \\
F\#3 - A4 & Average range: & Average range: \\
\hline
\end{tabular}


TABLE 4.5 Comparison of Ford's average range in top 5 highest charting singles to average across 5 lowest range songs and 5 highest range songs

\begin{tabular}{|c|c|c|}
\hline Top 5 highest charting hits & Lowest range songs & Highest range songs \\
\hline $\begin{array}{l}\text { Mocking Bird Hill } \\
\text { F3-G b4 }\end{array}$ & $\begin{array}{l}\text { I'm Confessin } \\
\text { E3 -E4 }\end{array}$ & $\begin{array}{l}\text { Tennessee Waltz } \\
\text { Eb3-Bb4 }\end{array}$ \\
\hline $\begin{array}{l}\text { How High the Moon } \\
\text { E3-E4, top voice belts A4 }\end{array}$ & $\begin{array}{l}\text { In the Good Old Summertime } \\
\text { E3 -E4 }\end{array}$ & $\begin{array}{l}\text { How High the Moon } \\
\text { E3-E4, top voice belts A4 }\end{array}$ \\
\hline $\begin{array}{l}\text { The World is Waiting for the } \\
\text { Sunrise } \\
\text { A b 3- B4 }\end{array}$ & $\begin{array}{l}\text { Take me In Your Arms } \\
\text { D3-E4 }\end{array}$ & $\begin{array}{l}\text { Tiger Rag } \\
\text { Top pitch D5 }\end{array}$ \\
\hline $\begin{array}{l}\text { Tiger Rag } \\
\text { Top pitch D5 }\end{array}$ & $\begin{array}{l}\text { Vaya Con Dios } \\
\text { E3-F4 }\end{array}$ & $\begin{array}{l}\text { The World is Waiting for the Sunrise } \\
\text { A b 3-B4 }\end{array}$ \\
\hline $\begin{array}{l}\text { Vaya Con Dios } \\
\text { E3-F4 }\end{array}$ & $\begin{array}{l}\text { I'm a Fool To Care } \\
\text { E3-E4 }\end{array}$ & $\begin{array}{l}\text { Whither Though Goest } \\
\text { E b 3-A } b 4\end{array}$ \\
\hline $\begin{array}{c}\text { Average range } \\
\text { F\#3 - A4 }\end{array}$ & $\begin{array}{c}\text { Average range } \\
\text { E3-E4 }\end{array}$ & $\begin{array}{c}\text { Average range } \\
\text { F3-B4 }\end{array}$ \\
\hline
\end{tabular}

\section{Interactive muse}

The pop partnership to which Ford would lend her voice resulted in a collection of records that are utterly unique in the postwar pop repertoire. The Paul/Ford recordings feature a distinctive sound palette, an eclectic selection of song material, a mixture of country style and jazz idiom peppered by the occasional "exotic" musical allusions. The arrangements combine predictability with surprise: while the records never stray far from initial melodic material, the sequence and the diversity of textures the pair present across a three-minute record can be dazzling.

Paul and Ford produced their array of familiar and novel sounds thanks to both their "raw materials" as well as through Paul's manipulation of their sounds with studio effects. To Ford's flexible voice was added Paul's guitar: he sometimes augmented his already-robust technique by speeding up his performances on final mixes, so that his fast passages sound superhuman. As he did with Ford's voice, Paul multi-tracked several lines of his guitar playing, combining a wide range of pitches and timbres on a given 
track, but always foregrounding a clean, bright guitar timbre - this is what gives many of the records their "sparkle."

The unusual and ambitious vision Paul had for his pop records was well served by Ford's musical skills that went beyond the flexibility of her voice. In fact, by the time Ford joined Paul, she had already thoroughly impressed her country music colleagues. Former collaborator Cliffie Stone spoke favorably of her to Shaughnessy: "She was a delicate talent with an amazing ear.... She sang quietly, succinctly and always in tune."14 Stone further commented on Ford's guitar skills:

But the most remarkable thing about her was her guitar playing. She was a terrific rhythm player, which was very hard to find. She had such a natural feel for the instrument. I eventually started giving her lessons on upright bass. She was already playing bass notes on the guitar, so it was merely a matter of teaching her proper fingering and how to use a bow. She picked it up immediately....It was very unusual to find the combination of talents Mary had. $^{15}$

While there is no indication that Ford carried on with bass playing in any serious way, it is clear that she was a quick learner. Guitarist Bucky Pizzarelli, who first saw the duo perform in 1958, told Shaughnessy how Ford's facility with the guitar took him by surprise: "She was supposed to be doing these little throwaway bits, just filler, but she was playing brilliantly."16

For his part, Paul acknowledges Ford's musical gifts in his autobiography: "She

\footnotetext{
${ }^{14}$ Shaughnessy, Les Paul, 150.

${ }^{15}$ Shaughnessy, Les Paul, 150.

${ }^{16}$ Shaughnessy, Les Paul, 235-6.
} 
learned quickly and never forgot anything, and she had a great sense of rhythm. She played just excellent, solid rhythm guitar, which was an important part of our sound. And it was another gift. Lead guitar players are everywhere, but good rhythm players are very rare." ${ }^{17}$ Paul also admired Ford's "ear like a hawk," ${ }^{18}$ and enjoyed the fact that they both had near-perfect pitch, shown by a story he recounted to Shaughnessy:

Mary's ear and my ear were pretty well matched....We'd be [driving] out in New Mexico somewhere and we'd tune in to the hum of the motor. I'd say, 'That's A flat.' She'd say, 'It's A.' So we'd pull out the guitar and give it a strum to see who was right. She was something else. ${ }^{19}$

Not only did Ford bring guitar skills, a keen ear and sense of rhythm to the table, but she was also quick to learn, and willing to throw herself into Paul's unorthodox, sometimes painstaking recording practices. Shaughnessy recounts how the duo recorded "How High the Moon" from evening through to the early morning hours in a small onebedroom apartment. A friend who witnessed the session told Shaughnessy, "I think they did at least six takes of the thing. Les cut the rhythm track first. Then he laid down all the countermelodies. The son of a gun had worked out the whole arrangement in his head, and it sounded great. He was so happy when he finished that he cut another song on the same machine, with me playing accordion and Ford singing. ${ }^{, 20}$ This marathon recording session resulted in a mini-opus featuring twelve layered tracks that would constitute the duo's first number 1 hit. Although Paul generated the arrangement and directed the

\footnotetext{
${ }^{17}$ Paul and Cochran, Les Paul, 308.

${ }^{18}$ John Paulson et al., Chasing Sound! The Les Paul Story. Musician, Inventor, Architect of Rock " $n$ " Roll, vol. 1 videodisc (Northcote, Vic.: Manufactured \& distributed by Shock, 2007).

${ }^{19}$ Shaughnessy, Les Paul, 176.

${ }^{20}$ Shaughnessy, Les Paul, 185-6.
} 
session, Ford's understanding of his vision and her precise work are central to the record's success.

Ford further facilitated Paul's vision because she appreciated his recording aesthetic, including his desire to close-mike her vocals, which creates the intimate atmosphere of their ballads. Paul's close miking required deft performances with respect to "self-limiting," that is, monitoring one's own audio output so as not to overload microphones. In an interview for Audio magazine, Paul explained how he preferred a microphone position much more proximate to the performer, compared to the miking practices used during the swing era: "In the Big Band Era....you never walked right up to the mike. You never got right where you had lipstick on the mike, no." When asked what tools he used to limit sound input and to avoid distortion, Paul explained that he and Ford self-limited, i.e. controlled their output at the level of performance:

It's simple for me because I'm my own limiter. I didn't know the word "limiter"....I do my own balancing, controlling by playing the guitar. I'm looking right at a meter. And when Mary sings she's lookin' at the meter. I'm watching that meter all the time so that I don't overshoot or undershoot - that I keep the level up. I pick softer, I pick louder. ${ }^{21}$

The intimate sound of Ford's voice is so well captured on record thanks not only to Paul's choice of microphone position, but to Ford's ability to control her vocal output to, in Paul's words, "keep the level up" without overshooting.

While Paul acknowledges Ford's musical skills, he patently denies in his

\footnotetext{
${ }^{21}$ Paul Laurence and Bob Rypinski, “Interview with Les Paul,” Audio, December 1978, 56-7
} 
autobiography that she had any part of the conception of the duo's arrangements: "Mary was talented beyond belief with her voice and rhythm and sense of pitch, but she was not creative. She had to be led to the arrangements because it didn't come naturally to her."22 For Paul, then, there is an unequivocal difference between the "creation" and the "execution" of their recorded work. Yet, Paul also implies that Ford's skills were virtually a precondition for the records' coming into existence: "Mary had to lay down her vocal parts in a backwards order, and I had to do the same thing with all the instrumental parts.... Mary had a tremendous talent for being able to do this, and it was not an easy thing to do. I wouldn't even try it now.",23

The fact that Ford could not be replaced supports the idea that she was a necessary condition of the Paul/Ford act, and not simply a performer. After the couple separated, Paul sought out substitute vocalists with little success. In Chasing Sound!, Bucky Pizzarelli alludes to Ford's irreplaceability: “When she left I don't think Les could ever find anybody that could sing like that. Nobody, we searched all over New Jersey, all over, he had everybody. He had Miss Universe and all kinds of gals. And he would try them out at that little saloon on Route 17."24

Accepting that Ford was not a co-creator of the recordings in the generative sense, it is nonetheless difficult to accept that her skills had no bearing on Paul's musical imagination. The timbral possibilities of her voice, her keen sense of pitch and rhythm, her guitar playing and her quick learning all provided Paul not with just a talented coperformer, but with an expanded musical palette with which to envision new

\footnotetext{
${ }^{22}$ Paul and Cochran, Les Paul, 307.

${ }^{23}$ Paul and Cochran, Les Paul, 210.

${ }^{24}$ John Paulson et al., Chasing Sound!
} 
arrangements, and a facilitator for his emerging ideas. In this sense, she was what I call an "interactive muse." Unlike the mythological muse who inspires the artist unilaterally, Ford would have provided to Paul a continuous feedback loop of inspiration, since she was always by his side, ready to test out his ideas as he developed them.

\section{Performing marriage, projecting connection}

Although Ford and Paul first met to work together on Paul's 1945 hillbilly radio show, they did not marry until December 1949. It is not entirely clear when their musical partnership became a romantic one - it may have been in 1947 — but by the time the pair presented their novel records to the public as a musical duo, they were married. Their popularity as a musical act and married couple occurred during a time when strong promarriage trends permeated society. The proportion of married to unmarried people reached an all-time high during the postwar era. Elaine Tyler May summarizes this phenomenon in numbers:

Those who came of age during and after World War II were the most marrying generation on record: 96.4 percent of the women and 94.1 percent of the men .... Not only did the average age at marriage drop, almost everyone was married by his or her mid-twenties. ${ }^{25}$

May adds that this trend affected Americans from all classes and backgrounds, and that the median age for marriage dipped down to 23 for men and 20 for women. ${ }^{26}$ To be married was normal and to be unmarried was an aberration.

\footnotetext{
${ }^{25}$ Elaine Tyler May, Homeward Bound : American Families in the Cold War Era (New York: Basic Books, 1999), 14.

${ }^{26}$ May, Homeward Bound, ix, xii.
} 
Given these numbers, it is not surprising that attitudes evolved so that marriage was increasingly equated with "normality," where "normality" required not only marriage but gendered role division, whereby husbands were responsible for paid labor and wives for domestic labor. As Coontz says:

[T]he long decade of the 1950 s, stretching from 1947 to the early 1960 s in the United States.... was a unique moment in the history of marriage.... The cultural consensus that everyone should marry and form a male breadwinner family was like a steamroller that crushed every alternative view. $^{27}$

In this context it is understandable that as Paul and Ford grew in popularity, they increasingly sought to present themselves publicly as models of marital contentment. In an age of pro-marriage consensus, this would seem to be a sure way to further connect with listeners. The duo's radio show was a first opportunity to invite audiences to "get to know them" as a married couple. The Les Paul Show with Mary Ford ran on NBC radio starting in 1950. The fifteen-minute weekly program featured up to three musical performances per episode punctuated by friendly banter. In a typical episode, Paul assumes the role of host and leads the dialogue between songs. Ford plays his goodnatured respondent, replying to his questions and laughing at his jokes.

This early presentation of the couple as a couple is interesting in that it both adopts and pokes fun at normative postwar marital ideals. In several episodes, Paul jokingly refers to Ford as his "squaw," which she counters with a hearty, eye-rolling

\footnotetext{
${ }^{27}$ Stephanie Coontz, Marriage, a History: From Obedience to Intimacy, Or How Love Conquered Marriage (New York: Viking, 2005), 229.
} 
"ugh." The exchange comes off as an oft-repeated routine, as if the couple often carries on this way to tease each other and to entertain whoever is listening.

Although the radio program's musical performances were all pre-recorded, there is nevertheless a relatively naturalistic, "live" sound to many of them, suggesting that Paul did not invest as much effort in the production of these tracks compared to those he would release as commercial singles. Interestingly, these episodes provide some of Ford's most "unproduced" pop vocal performances available, and they are invariably of high quality: her tone is rich and steady, her intonation excellent, and her phrasing and ornamentation choices are subtle but compelling. Not only do these radio episodes suggest that Ford's singing was excellent with or without Paul's studio interventions, but what's more, her performance choices project more of a sense of a distinct musical identity than is palpable on the commercial singles.

It would seem that the format and tone of the radio show should have been replicable on the duo's television show Les Paul and Mary Ford at Home. This program began airing in 1953, and each five minute episode features the couple partaking in a domestic or leisure activity, some minimal dialogue, and the performance of two or three short musical numbers. By this time, the duo had attained a critical degree of success, and had settled in a large home in Mahwah, New Jersey, the on-location setting for the program. The show demonstrates the "normative" nature of the couple's domestic lifestyle: despite the fact that they are international music industry stars, the program suggests, their cozy home life consists of "everyday" chores and leisure pursuits. The trappings of television as a medium, however, work against their attempts to 
project this cozy image: neither Paul nor Ford have the charisma to fill up the small screen, so there is nothing natural-seeming or cozy about their presentation. Ford, especially, seems uncomfortable and stilted to the point of near paralysis. Whether singing or reciting the "casual" lines of the script, she barely moves her body, and when she speaks, her face seems frozen in a smile.

What is worse is that their musical performances lose impact, rather than gain impact, through the televised medium. The musical performances are pre-recorded, so Paul and Ford are synching on screen. This in and of itself does not make a filmed performance unsuccessful—most film musicals and some television shows were routinely produced in this manner. However, unlike on the radio show, the musical numbers on the television show are highly multi-tracked. Paul and Ford's records are so very mediated in their production that the endeavor to present them as spontaneous and live in televised format is unpersuasive and unsettling.

The television show was rather inconsequential with respect to the couple's musical and media output and therefore did not attract much commentary or criticism. It is likely that historical audiences would not have had a particularly negative reaction to them: television was still a new medium, and its novelty likely invited audiences to enjoy the programs without a critical mindset. Viewed today, however, what is striking is the extent to which the couple sought to project the image of contented domesticity with at best mixed results.

Alongside the couple's own presentations, images of them as would-be models of marital contentment appeared in the press. But, as Steve Waksman notes, these pieces 
have a tendency to undercut the image they purport to present. Waksman points to a 1953 Newsweek article that describes a "typical day" in the home of the couple. The article's prose describes Ford and Paul as engaged in a pleasant combination of work and leisure, owing to their ability to produce all their recordings in their home studio. However, the photos show Ford and Paul to be constantly separated in different parts of the house or engaged in different activities, with Paul photographed around the sound equipment and Ford photographed doing housework. Waksman suggests that this separation reveals the gendering effects of technology in the home: rather than modernizing and equalizing gender relations, the postwar trend of increased technology in the home tended to reinscribe the separation of gendered spheres. ${ }^{28}$ Waksman is right to point out that in this Newsweek piece Paul is marked as the team's technical wizard in a way that minimizes Ford's role as a contributor to the duo's output. I further take Waksman's point as an example of the couple's purportedly ideal marriage that in fact reads as less than ideal, whether because of signs of stiltedness, discomfort or separation.

Meanwhile, a review of a 1953 live performance by Paul and Ford recalls the radio show's mood of casual warmth and friendly teasing. Critic Richard Coe writes of the duo's Washington DC engagement:

Mr. and Mrs. Paul are quite a couple, as no doubt you've heard from their 10 million discs in the folksong style. They have the happy faculty of seeming to indulge in a private party of their own while they play such things as "Mocking Bird Hill," "Bye, Bye, Blues" or "Tiger Rag" on their

\footnotetext{
${ }^{28}$ Waksman, "Pure Tones and Solid Bodies," 65.
} 
peculiarly strident machines. They have a genius for being themselves with that if-you-don't-like-us_-go-home approach. This kind of honesty, or seeming honesty, is excellent if it can be got away with, and the Pauls are terrific at it. .... Their easy-going way with harmonies that are remarkably intricate, and their kidding around about who's going to attack a phrase first, are amusing and delicately deft. ${ }^{29}$

In this live concert setting, the duo are not performing the role of a "normal" domestic couple who place as much importance in housework and home leisure as they do in performing. The cozy atmosphere and warm connection they project from the stage could certainly suggest a happy marriage - just not a marriage that is tied to happiness at home and domestic pursuits.

To the extent that the couple's onstage chemistry may have pointed to real-life romantic and sexual connection, this reflected a different set of postwar marriage ideals, ones that were not directly tied to domesticity. Alongside the retrograde reinstatement of Victorian-era gender division and domesticity, marriage ideals with respect to emotional and sexual connection remained distinctly "modern" in the postwar era.

The 1920s marked a turning point in conceptions of marital sexuality in the United States, and these extended to the postwar era. Before the 1920s, a Victorian view of marital sexuality prevailed, holding that sexuality was a "necessary evil," and that sexual urges, even within marriage, needed to be repressed outside of procreative duty. ${ }^{30}$ However, beginning in the 1920s, doctors and other experts began to endorse new

\footnotetext{
${ }^{29}$ Richard L. Coe, “Electric Guitars Liven Capitol Bill,” Washington Post, February 6, 1953.

${ }^{30}$ John D'Emilio and Estelle B. Freedman, Intimate Matters : a History of Sexuality in America, vol. 1st Perennial Library (New York: Perennial Library, 1989), 265.
} 
conceptions of marital happiness. John D'Emilio and Estelle Freedman show this change by comparing older and newer marriage manuals. The nineteenth century handbooks emphasize sexual control, whereas by the 1920s and 1930s they encourage sexual expression, and there is an increased agreement that sexual connection and fulfillment was crucial for the psychological wellbeing of a married couple. ${ }^{31}$

This more modern view of marital sexuality persisted into the $1950 \mathrm{~s}$, even as couples were encouraged to adopt more traditional gender roles with respect to division of labor and domestic endeavors. Elaine Tyler Mary notes how sexual expression within postwar marriage was endorsed and considered essential, and that particular importance rested on women's keen participation: “Unlike Victorian mothers who were expected to be reluctant sexual partners who tolerated sex for reproduction only, wives in the postwar era were recognized as sexual enthusiasts whose insistence on conjugal satisfaction would contribute to erotically charged marriages." 32 Also carrying through from the 1920s was the idea that marriages would be most successful if the partners were emotionally well connected. In his manual Companionate Marriage, Ben Lindsay emphasized not only the importance of mutual sexual satisfaction for husbands and wives, but also advocated that marriage required emotional compatibility. ${ }^{33}$ By the postwar era, this would come to mean not only an ability for partners to relate emotionally but also to be able to embrace the new "fun morality" together, to enjoy each other's company in the pursuit of leisure. ${ }^{34}$

\footnotetext{
${ }^{31}$ D'Emilio and Freedman, Intimate Matters, 267.

${ }^{32}$ May, Homeward Bound, 90.

${ }^{33} \mathrm{D}$ 'Emilio and Freedman, Intimate Matters, 266.

${ }^{34}$ Coontz, Marriage, a History, 233.
} 
While there is no doubt that Paul and Ford's image as a couple touched on the postwar ideal of domesticity, it is unclear the extent to which they were successful in projecting that image with ease and naturalness. On the other hand, a non-domesticcentered romantic/sexual chemistry between the pair emerges from their radio show and their live performances. This palpable connection may have resonated with audiences who hoped for emotional and sexual connection in their own marriages.

If onstage chemistry between Paul and Ford was an important dimension of their live shows, it is plausible that at least some of this chemistry might have made its way onto their recordings. Of course the novel soundscapes, virtuosic performances and exciting arrangements certainly drew listeners to the Paul/Ford recordings. But if the couple also projected a "marriage persona" that suggested emotional and sexual connection, this might have further endeared them to listeners.

\section{Mary Ford, (discreet) sex symbol}

While Billboard reviewers most often describe Ford's voice as "warm," and "tender," there is also a suggestion that commentators hear a desirable sexuality in her singing. ${ }^{35}$ However, the first reviews of the duo's records do not accord positive attention to Ford's voice. For example, in the review of "Jealous" (1950) Billboard notes that the record contains a "trick" vocal (the term they used for overdubbing), but says nothing about the quality of Ford's vocal. ${ }^{36}$ As for the duo's version of “Tennessee Waltz," which rose to number 6 in the wake of Patti Page's smash success with the song,

\footnotetext{
${ }^{35}$ It may be that this line of commentary is muted because writers recognize that, as a married woman, Ford is not "available" as a sex symbol in the same ways that her solo female contemporaries are.

${ }^{36}$ Billboard, June 3, 1950.
} 
Billboard compares Ford's voice unfavorably to her competitor's: "Mary Ford duplicates Patti Page's duet with herself but her warbling hasn't the potency of the original.",37 But after the success of "How High the Moon," critics begin to appreciate the appeal of Ford's solo voice. Of "Just One More Chance," Billboard says, “"Chance' is Miss Ford's side — a reasonably straight, and very sincere performance of the ballad standard." ${ }^{38}$ Later in the issue the same song is deemed a "very compelling torch side that could hit on sheer sentiment." From this song onward, similar descriptors of Ford's ballad delivery follow: her voice is "mighty warm," 39 she sings with "tender feeling,"40 and she provides a "warm, soft reading of [a] lovely oldie.".41

Although reviewers do not describe Ford as "sexy" or "sultry" they use vocabulary that borders on the sensual: a reviewer of "I'm a Fool to Care" notes that Ford "caresses the song" with her voice, ${ }^{42}$ and a live concert reviewer suggests that Ford "purrs" her lyrics. ${ }^{43}$ Attention is drawn to Ford's body, if indirectly, with the compliment that she has "honeyed pipes.",44

The restraint with which Billboard reviewers ascribe sexuality to Ford's singing may reflect propriety with regards to her married status, or simply the fact that outside of her singing, Ford did not present a particularly glamorous or vivid persona that captured the imagination. Additionally, the hushed discretion with which writers approach Ford's

\footnotetext{
${ }^{37}$ Billboard, December 9, 1950, 66. "Warbling" here is neither a compliment nor a dismissal; just one of many pieces of industry jargon that fills the pages of Billboard.

${ }^{38}$ Billboard, October 13, 1951, 33.

${ }^{39}$ Billboard, August 9, 1952, 42.

${ }^{40}$ Billboard, October 18, 1952, 48.

${ }^{41}$ Billboard, May 3, 1952, 37.

${ }^{42}$ Billboard, June 12, 1954, 40.

${ }^{43}$ Billboard, May 8, 1954.

${ }^{44}$ Billboard, January 14, 1956.
} 
sexuality may parallel postwar attitudes about marital, or "wifely" sexuality more generally. This was an era in which marital sexuality was strongly endorsed and wives were hoped to be, in May's words, "sexual enthusiasts." And yet, this was still a relatively private era in matters sexual compared to the decades that would follow. The fully sanctioned, and ideally charged sexual act remained a private experience between husband and wife: only in the seclusion of the marital bedroom would the ideal postwar wife reveal her sexual self.

Ford's performance in "Take Me In Your Arms" may illustrate the discreet sexuality that Billboard reviewers hear in Ford's singing. The song was written by country songsmith Cindy Walker, and first made famous in 1949 by country singer Eddy Arnold. Paul and Ford would release their version in August 1952.

The lyrics present a "real-time" description of emotional and physical intimacy of a couple reunited after a separation. The song is in 32 bar AABA form, and in their recording, Paul and Ford perform one full chorus plus a half chorus.

The song's harmonic progression includes several applied dominants and a local tonicization, all of which introduce a degree of harmonic motion and tension unusual for a postwar pop song. (See table 4.6.) Over top of this progression, the melodic contour of the A section is very disjunct: the first eight measures include a descending third, an ascending fifth, a descending octave, an ascending seventh, then descending and ascending sixths.

Ford masks the disjunct quality of the melody because she delivers the line with such steadiness and evenness. This is possibly in part due to the duo's decision to record 
the song in the key of F, allowing Ford to sing in the lowest register of her voice, dipping down to D3. With the exception of one F4, Ford's highest note is E b 4. The choice of F major allows Ford to maintain an evenness of timbre and dynamics-breathy and softthroughout.

Beyond her timbre and dynamics, Ford's nuances of pronunciation help to maintain a soft and steady vocal line. She avoids the glottal stop normally used for pronouncing words that begin with vowels, thereby preventing a rupture in her breathy tone: she does this on the word "arms" (m.2) by adding a very faint " $\mathrm{h}$ " to the word, thereby saying "harms" instead of "arms." (Though not perceptibly on a casual listen.) On the word "in" (m.1), Ford quickly moves to the "n" sound, effecting an "n-hmm" which is easier to sing softly than a sung vowel.

Aspects of the recording beyond Ford's singing bolster the mood of intimacy. The close-miked recording allows for audibility of consonants " $\mathrm{t}$ " and " $\mathrm{k}$ " every time Ford pronounces the words "take me." The fact that these consonants are so audible in Ford's singing conveys the sense that she is close by, and singing very softly, suggesting intimate, palpable presence.

Within the context of a harmonically and melodically gymnastic song, Ford delivers her vocal line with low-pitched, low-dynamic steadiness. Her smooth negotiation of leaps suggests attentiveness, care and control. Her low breathy voice and her delicate consonants convey palpable closeness. Taken together these qualities may have been experienced as a sonic image of the ideal, discreetly sexual postwar wife, who reveals her sexual self only in the most private and intimate of spaces. 
TABLE 4.6 Harmonic progression of "Take Me In Your Arms"

\begin{tabular}{|c|c|c|c|c|c|c|c|}
\hline \multicolumn{8}{|c|}{ A section - first 8 measures } \\
\hline m.1 & $\mathrm{m} .2$ & m.3 & $\mathrm{m} .4$ & $\mathrm{~m} .5$ & m.6 & $\mathrm{m} .7$ & $\mathrm{~m} .8$ \\
\hline I & $\mathrm{V} \# \rightarrow$ & $\mathrm{V} \nvdash \rightarrow$ & & V7 & & I & \\
\hline $\mathrm{F}$ & $\mathrm{D}$ & G & & C7 & & $\mathrm{F}$ & \\
\hline \multicolumn{8}{|c|}{ B section } \\
\hline$[b \|$ & $\mathrm{V} \#] \rightarrow$ & II & & $\mathrm{V} \# \rightarrow$ & & Vnat7 $\rightarrow$ & V7 \\
\hline$A b$ & $\mathrm{D}$ & $\mathrm{Gm}$ & & $\mathrm{D}$ & & G7 & C7 \\
\hline
\end{tabular}

FIGURE 4.1: "Take Me In Your Arms" excerpt

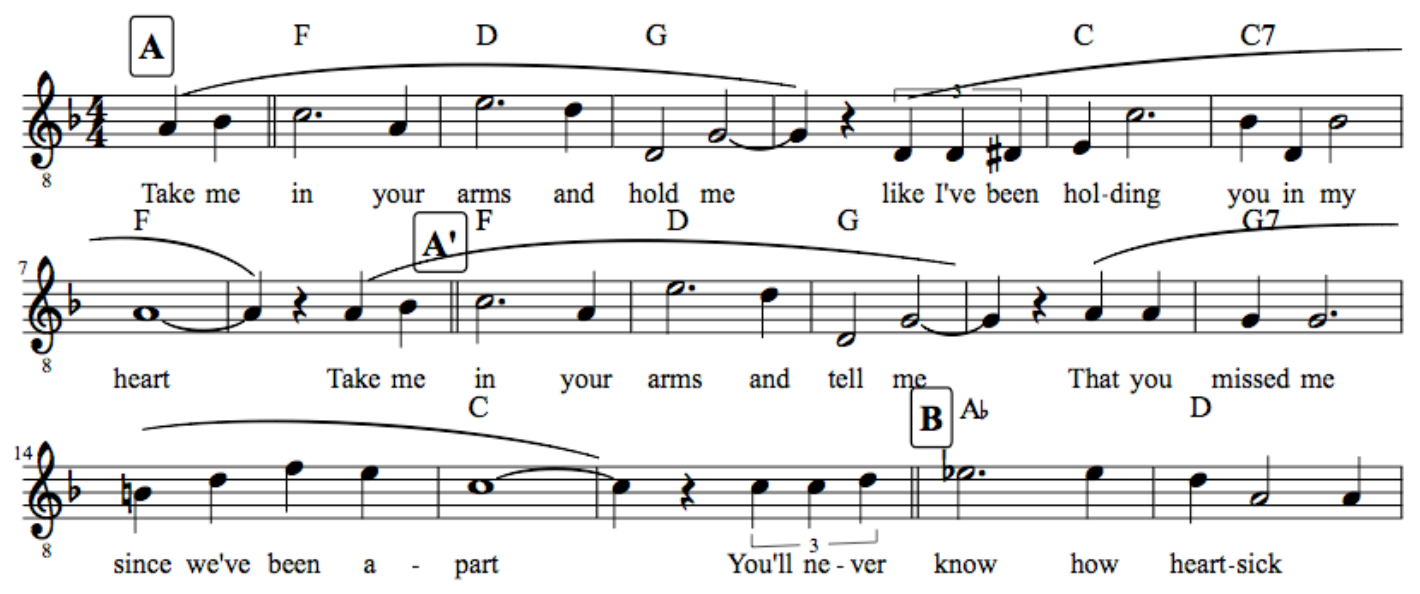

\section{Alone together}

While "Take Me In Your Arms" may be read as sonic image of Ford as discreet

"wifely" sex symbol, "Just One More Chance" suggests a sexual connection between 
Ford and Paul. Bing Crosby first made "Just One More Chance" famous in 1930. Paul and Ford released their version in 1950. The song is in 32-bar AA'BA chorus form, and the duo performs in a moderately slow tempo with gentle swing.

The lyrics present a speaker who attempts to win back her lover after an unspecified transgression. However, aspects of the lyrics and melody suggest that the speaker is trying to charm and beguile rather than win back her lover through a good faith apology. She uses several rhetorical means to persuade him including a demonstration of religious conviction ("Each night I say a little prayer"), flattery ("to taste the kisses that enchant me"), pathos ("now I'm back to cry my heart out"), and an extended judicial metaphor ("Now you're the jury at my trial/I know that I should serve my sentence.") The "pull out all the stops" nature of this entreaty suggests that she is not so much humble and repentant as experiencing herself as a pathos-worthy creature who deserves to be forgiven and relieved of her misery.

The melodic construction of the song bolsters this reading of the lyrics - that the speaker is being circular rather than direct. The melody avoids the tonic until the second last measure of A'. During the 15 measures preceding tonic arrival, the melody leaps over the tonic several times without landing on it. (See figure 4.2.) In this song, Ford does not use not the low breathy voice of "Take Me In Your Arms," but rather a fuller, richer tone. She sings within E3 and E4, which allows mostly for a comfortable, unstrained sound. The only exception is when she leaps up to E4, there is just enough edge to her tone to suggest pleading, but without discomposure. Overall, Ford's vocal performance presents a pleasant lulling quality as she works her way up and down the E3-E4 octave. 
Ford's vocal persona, with its pleasantly hypnotic charm, is supported by Paul's guitar interactions as he punctuates her lines between phrases. (See figure 4.3) This sonic contrast is effective and pleasurable in a few ways. First, because the bright and focused guitar tone and guitar register contrast with that of Ford's voice. Paul also provides melodic contrast through directional counterpoint: when Ford sings an ascending line, he responds with a descending (albeit zigzagging) line with a "wonky" pitch cluster. This pitch cluster [E F\# G\#] moves to [D\# F G] and then to [D E F\#]. It provides color in and of itself, but it is not without harmonic content. In its first iteration, two of the notes of the pitch cluster are chord tones (in the chord Amaj7) and in its third iteration, the pitch cluster creates an E7 chord with an added $9^{\text {th }}$. Heard this way, the second pitch cluster is a passing chord between the first and third. The "zig zag gesture" is thus both oddly colorful, and somewhat harmonically cogent.

Finally, Les Paul's zigzag gesture helps rhythmically: it outlines the groove and rhythm of the piece. These are otherwise hard to determine, since Ford starts singing on the downbeat without introduction, and her half note/quarter note/quarter note opening tells us little about meter or groove. Paul's first zig zag line introduces and then takes on the song's groove (swing) and pulse/tempo. His lines also serve as anchors that allow Ford to sing slightly "lazily" behind the beat.

The way Paul ornaments and adorns Ford's performance might be read as intimate physical exchange. The sonic balance between their lines, and the give and take quality of their musical dialogue might suggest passionate, quiet, lovemaking.

As well as providing musical support and counterpoint to Ford's vocals, Paul's 
guitar lines also provide extra meaning to the song's lyrics by musically demonstrating "how charm works." For example, at m. 8, after Ford finishes the verse with the lyrics “Just one more chance," Les Paul plays a filigree gesture, ornamenting Ford's last note. He approaches her last pitch from below, performs a turn around it, then jumps up the octave to the upper neighbor and delicately trails off.

This ornamentation adds emphasis and meaning to Ford's lyrics in the following sense. After Ford sings the lyric "Just one more chance" (an entreaty), Paul tags on his filigree gesture, helping her to punctuate her question with a hopeful question mark. It is as if she is batting her eyelashes coyly waiting for an answer. This sequence allows the Ford persona to present herself as sober and direct, taking ownership of her past mistakes; but she lets Paul's guitar augment her words with wordless gestures. The pairing suggests how seductive or charming people can say one thing with their words, but something else with their gestures, or tone, or demeanor.

Paul's persona in this song_-insofar as his persona as "guitar player" emerges in the song - does not appear to be the addressee of Ford's speaker, because Paul's gestures are not easily read as "answers" to her lines. Instead, he seems to be helping her cause: he augments her charm and seductive power with his delicate gestures. We might read from this that Paul is conspiring with Ford to make her as charming as possible; that he and she are a single persona performing the song to an outside addressee. Or perhaps we might understand that Paul's persona is one-part helping the Ford's persona project as much charm as possible; and one-part enamored with her himself. "How could anyone stay mad at a woman, no matter what she's done, if she's as beguiling as my wife?" his 
guitar seems to ask. As well as depicting sonically a charged marital connection, this song may illustrate Paul's attraction to his wife.

\section{FIGURE 4.2 "Just One More Chance" melody AA' section}
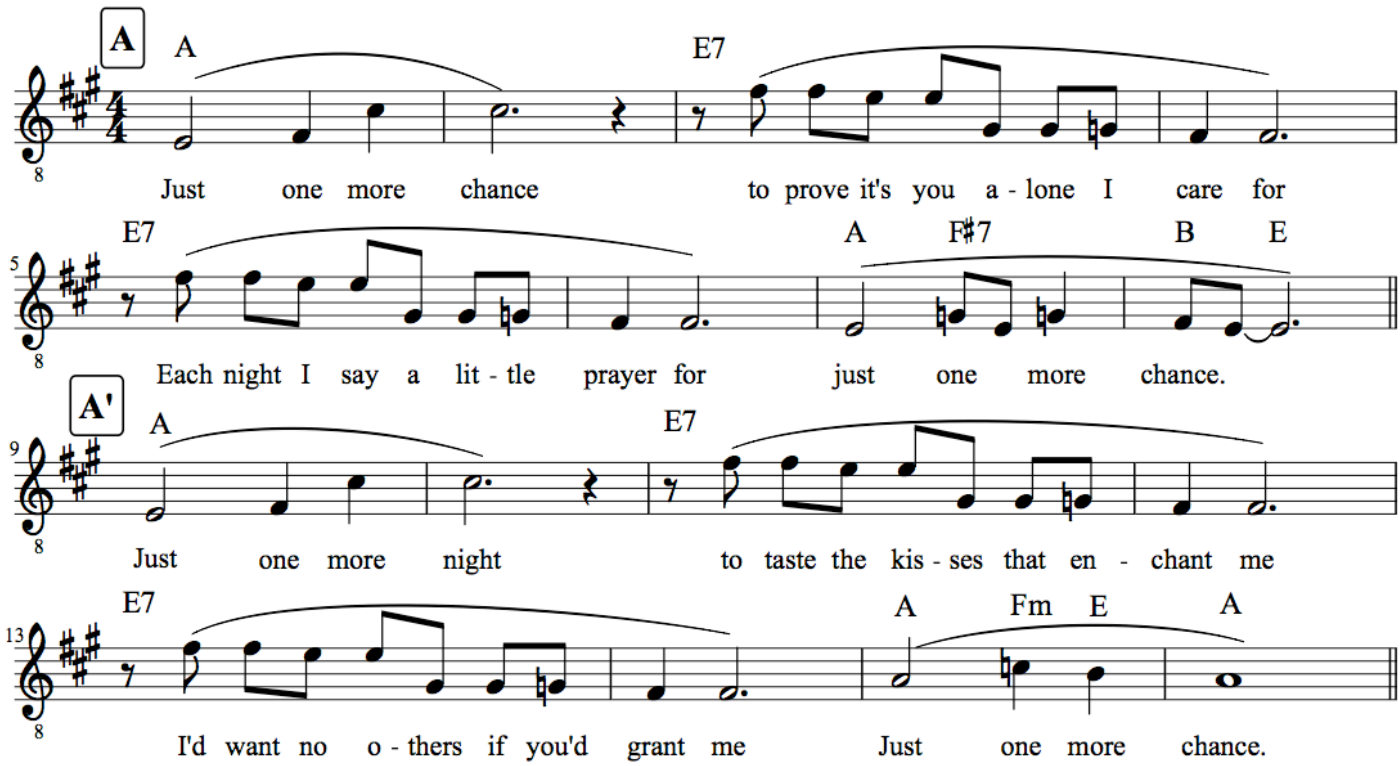
FIGURE 4.3 Voice-guitar interaction in Les Paul/Mary Ford's "Just One More Chance"

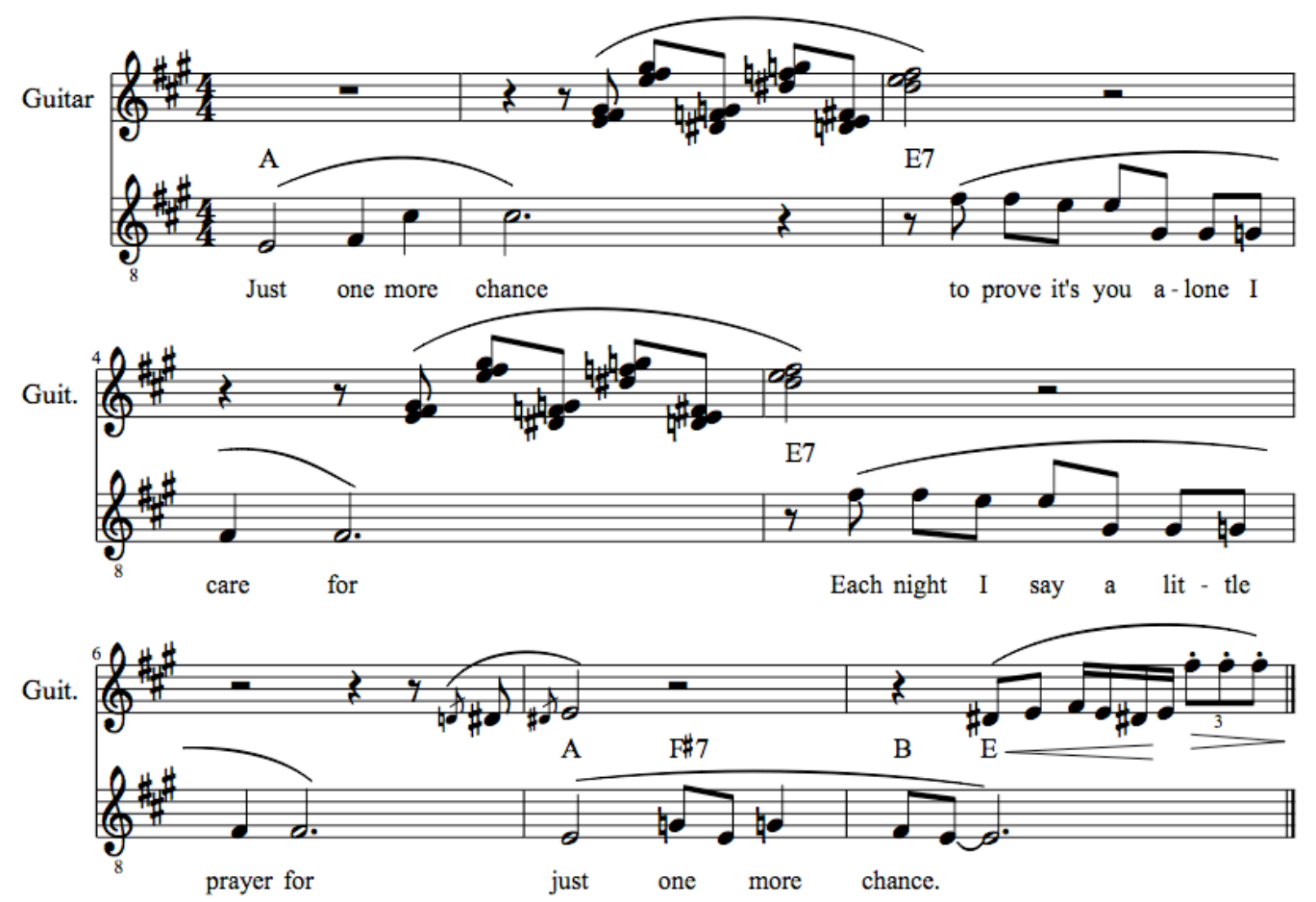

\section{Together, in flight}

In contrast to the languorous, lulling Paul/Ford ballads, "How High the Moon" dazzled audiences with its sparkle and speed. It was the duo's first number one hit, and upon its 1951 release, Billboard glowed, "[Les] Paul, blazing hot on wax at the moment, has produced a gem in this unusual treatment of the standard. Effort is keyed around his guitars, multiple-dubbed a dozen times, and a vocal dubbing job which produces a choral effect. Has a country flavor which could draw action in folk sectors as well.",45

This positive reception is at least partly linked to the fact that Paul and Ford were able to offer such a novel iteration of a ten-year-old standard. The song was written by

\footnotetext{
${ }^{45}$ Billboard, March 24, 1951.
} 
Nancy Hamilton (lyrics) and Morgan Lewis (music) for the 1940 Broadway musical Two for the Show and was soon after covered by Benny Goodman. It would become a signature song for Ella Fitzgerald in 1947, and a vocal showpiece for June Christie with Stan Kenton in 1948. In the jazz world, the song is notable for giving rise to Charlie Parker's 1946 “Ornithology,” a contrafact of "How High the Moon.” For his part, Les Paul had released a V disc of the tune with his jazz trio in 1945, but he wished to record a new version with Mary Ford. Capitol Records initially refused Paul's request: by 1950, the label had already made 23 recordings of the song by various artists and saw no more commercial potential for the composition. But Paul persisted and eventually won; and critics and record buyers proved the label wrong. ${ }^{46}$

Novelty and freshness permeate all aspects of the Paul/Ford version of "How High the Moon" including style, timbre, performance, form and arrangement. Like many of the duo's records, this one mixes elements of jazz and country into an accessible pop blend. Paul's lengthy solo, spanning 49 measures of a 123-measure song, owes much to jazz solo style in his use of melodic paraphrase and harmonic improvisation. Yet many of Paul's gestures are more country than jazz or pop: his solo is peppered with moments of countryish twang.

The sound world created by the record was novel for postwar listeners: it combines twelve layered tracks, four of which feature Ford's voice, and another eight that are devoted to lead, rhythm and bass guitar lines. Beyond the sheer quantity of sound is its striking quality: Paul's bright, sparkling guitar rings out, and Ford presents a varied

\footnotetext{
${ }^{46}$ Shaughnessy, Les Paul, 186.
} 
array of vocal timbres. This soundscape is a marked departure from all previous versions of the song, which feature traditional jazz instrumentation.

Perhaps the most exciting difference from previous versions is the couple's approach to form. The tune is in 32-bar ABAB' chorus form, and previous artists who recorded it adhere to jazz-pop norms in presenting a series of choruses, sometimes including a half-chorus at the end. Musical interest in these early versions arises through the quality of performance, through soloing or through the variation of instrumentation over top of the fixed harmonic structure. (See tables 4.7 and 4.8.)

In contrast to any of these versions, it is easier to conceive of the Paul/ Ford version as composed of sections, not choruses. (See table 4.9.) Section 1 comprises a full vocal chorus, but sections 2 and 3 do not. In section 2, the full harmonic progression ABAB' never gets to unfold. Instead, the harmony gets "stuck" on $A B$, and the AB halfchorus progression becomes a unit for vamping, over which Paul plays his extended solo. Section 3 consists of a half chorus (AB'), a common way to end a postwar pop tune. But what is uncommon here is that the harmonic rhythm of the final AB' is slowed in half.

The formal novelty of the Paul/Ford version allows for surprise and pleasurable contrasts: Paul's solo in section 2 builds tension in that it goes on "too long," and in that it disallows an expected return to the tonic. When section 3 finally arrives, the tension subsides; Ford's reprise of the lyric suggests the duo are "wrapping up," and "heading home." However, the unexpected change in harmonic rhythm creates a dreamy, floating sense. Time seems to have stretched out.

While the musical creativity and stylistic hybridity that Paul and Ford pour into 
"How High the Moon" was likely a main draw for postwar listeners, their "couple persona," as it emerges through music, may also play a role in the song's appeal. The breathless tempo of the performance, the charged interactions between voice and guitar, and the sense of adventure conveyed through the duo's formal innovation all work to project the sense that this is a fun-loving couple basking in each other's company and enjoying their musical journey together.

The relationship between Ford's voice and Paul's guitar presents balance and also intense connectedness. Formally, the arrangement allows each performer a chance to dominate the musical foreground. Ford starts "center stage," then yields to Paul's solo. When Ford returns for the final section, her voice is in the foreground, but Paul's guitar is woven into the texture, giving him more of a constant presence compared to the first section during which he "answers" rather than "accompanies" Ford.

But beyond the balance at the level of the form, there is also a sense of connectedness between the artists in terms of how they support or interact with each other at the levels of section and phrase. For example, in section 1, when Ford is singing, Paul punctuates her lines with short gestures that seem to comment and urge her on. Then, in anticipation of his solo at section 2, Paul plays a three-beat pick-up that barely allows for Ford to finish her last lyric ("how high the moon.") This hasty anticipation may convey Paul's impatience to take the spotlight, but it might equally express excitement about the musical partnership: as if Ford's first vocal chorus has imbued him with such energy that he is compelled to take over (relay-race style) and renew the musical energy with his own means. When Ford re-enters, it is as if she were in turn compelled by Paul's solo. It is as 
if her ascending multi-tracked "ahhs" are deployed to "carry him through" to the last portion of his solo.

Finally, when considered as a whole, the three-part structure of the Paul/Ford arrangement might be heard as a narrative of romantic or sexual bliss, where section 1 is "hot," section 2 is "hotter" and section 3 presents, rather than a return to the cooler character of section 1, a blissful plateau that extends the heat of section 2 .

Section 2 builds in energy from section 1 because of the breakdown of formal expectations and because of Paul's lengthy solo. Ford's choir of “ahhh's" then pushes section 2 to its climax. For its part, section 3 does not simply resume the character of section 1 . The pulse for section 3 is continuous from section 2 , but the harmonic rhythm and the pace of lyrical delivery are cut in half. Further, across every musical element, there is a change from music that evokes verticality to music that evokes horizontality. The section 3 backup vocals provide simple counterpoint (rather than block chord harmony) moving slowly, and with little syncopation to create rhythmic contrast. The bass guitar line, triadic and disjunct in section 1, becomes stepwise. The lead guitar, which created sharp, groovy punctuations in section 1, now plays an unaccented steady ostinato. (See table 4.10.)

All of this creates in section 3 a sense of floating, stretched time, in contrast with the more dug-down, swinging groove of sections 1 and 2. One possible reading of this expansive section is well reinforced by the lyrics: it is the idea that the couple have literally "taken off": their virtuosic playing has propelled them to the heavens. Marketing material supports this reading: an advertisement for the record features Ford hovering 
atop Paul's guitar with the moon in the background. Clearly the idea that this song "takes flight" was part of Paul's vision, and his marketing team agreed that this was a tenable association for the song. And integral to making this song "take flight" is section 3 with its floating, soaring quality.

However, an additional, complementary reading is possible if we consider the narrative of the song as a dialogue and intimate exchange between the couple. If section 1 is hot, and section 2 further heats up, and then builds to a climax, section 3 could be a sonic depiction of sexual, possibly post-coital bliss, wherein the duo bask in their connection, for the moment floating in their own private sonic/sexual world.

TABLE 4.7 Basic form of "How High the Moon" (32-bar chorus ABAB')

\begin{tabular}{|c|c|c|c|c|c|c|c|c|c|}
\hline & Lyrics & m1 & $\mathrm{m} 2$ & m3 & m4 & m5 & m6 & m7 & $\mathrm{m} 8$ \\
\hline A & Somewhere there's music... & A & -- & Am & -- & $\mathrm{G}$ & -- & $\mathrm{Gm}$ & -- \\
\hline $\mathrm{B}$ & There is no moon above... & $\mathrm{Fm}$ & $E$ & $\mathrm{Am}$ & -- & $\mathrm{A}$ & -- & $\mathrm{E}$ & -- \\
\hline A & Somewhere there's music... & A & -- & $\mathrm{Am}$ & -- & G & -- & $\mathrm{Gm}$ & -- \\
\hline $\mathrm{B}^{\prime}$ & The darkest night... & $\mathrm{F}$ & $E$ & A & -- & $E$ & -- & A & -- \\
\hline
\end{tabular}

TABLE 4.8 Comparison of formal structures in five recordings of "How High the Moon"

\begin{tabular}{|c|c|}
\hline Artist & Form \\
\hline $\begin{array}{l}\text { Benny Goodman } \\
1940\end{array}$ & $\begin{array}{l}\text { Chorus 1: } A B A B^{\prime} \text { instrumental } \\
\text { Chorus 2: } A B A B^{\prime} \text { : vocal (vocalist?) } \\
\text { Chorus 3: } A B^{\prime}: \text { instrumental }\end{array}$ \\
\hline $\begin{array}{l}\text { Les Paul Trio V Disc } \\
1945\end{array}$ & $\begin{array}{l}\text { Chorus 1: } A B A B^{\prime} \\
\text { Chorus 2: } A B^{\prime}\end{array}$ \\
\hline Ella Fitzgerald 1947 & $\begin{array}{l}5 \text { full choruses; all vocal, all ABAB' } \\
\text { Chorus 1: some melodic improv second half } \\
\text { Chorus 2: altered lyrics } \\
\text { Chorus 3: scatting } \\
\text { Chorus 4: scatting (quoting “Ornithology") } \\
\text { Chorus 5: improvised words } \\
\text { Coda }\end{array}$ \\
\hline $\begin{array}{l}\text { Stan Kenton/June } \\
\text { Christy } 1948\end{array}$ & $\begin{array}{l}\text { Chorus 1: } A B A B^{\prime} \text { vocal } \\
\text { Chorus } 2 A B A B^{\prime} \text { instrumental } \\
\text { Chorus 3: } A B A B^{\prime}: \text { ( } A B \text { - instrumental; } A \text {; scatting; } B^{\prime} \text { vocal (lyrics) }\end{array}$ \\
\hline Les Paul/Mary Ford & Section 1: ABAB' Vocal \\
\hline
\end{tabular}




\begin{tabular}{|l|l|}
\hline \multicolumn{1}{|c|}{ Artist } & \multicolumn{1}{c|}{ Form } \\
\hline 1951 & $\begin{array}{l}\text { Section 2: ABABAB instrumental } \\
\text { Section 3: } A B^{\prime} ; \text { harmonic rhythm halved }\end{array}$ \\
\hline
\end{tabular}

TABLE 4.9: Formal structure of Les Paul/Mary Ford's “How High the Moon”

\begin{tabular}{|c|c|c|c|c|c|}
\hline Section & Measures & $\begin{array}{l}\text { Duration } \\
\text { (measure) }\end{array}$ & $\begin{array}{l}\text { Formal } \\
\text { material }\end{array}$ & Texture & $\begin{array}{l}\text { "Marital } \\
\text { narrative" }\end{array}$ \\
\hline Intro & $1-8$ & 8 & & & \\
\hline 1 & $9-40$ & 32 & $\mathrm{ABAB}^{\prime}$ & $\begin{array}{l}\text { MF vocals; ABAB' lyrics } \\
\text { LP lead guitar punctuations }\end{array}$ & "Hot" \\
\hline $2 a$ & $41-56$ & 16 & $A B$ & $\begin{array}{l}\text { MF tacit } \\
\text { LP lead guitar solo }\end{array}$ & \multirow[t]{3}{*}{ "Hotter" } \\
\hline $2 b$ & $57-72$ & 16 & $A B$ & $\begin{array}{l}\text { MF vocals m } 69 \text { "ahh" } \\
\text { LP lead guitar solo continues }\end{array}$ & \\
\hline $2 c$ & $73-89$ & $17(16+1)$ & $A B$ & $\begin{array}{l}\text { MF vocals "ahh" continue ", } \\
\text { tacit m } 78 \\
\text { LP lead guitar solo continues }\end{array}$ & \\
\hline $3 a$ & $90-105$ & 16 & $A$ & $\begin{array}{l}\text { MF vocals; A lyrics } \\
\text { LP contrapuntal lead guitar }\end{array}$ & \multirow[t]{2}{*}{ "Bliss" } \\
\hline $3 b$ & $106-123$ & $\begin{array}{l}18(8+5+ \\
5)\end{array}$ & $B^{\prime}$ & $\begin{array}{l}\text { MF vocals; B' lyrics; } \\
\text { LP contrapuntal guitar }\end{array}$ & \\
\hline
\end{tabular}

TABLE 4.10 Texture differences between section 1 and section 3 of "How High the Moon"

\begin{tabular}{|c|c|c|}
\hline Musical element & Section 1 & $\begin{array}{c}\text { Section } 3 \text { to the end of } \mathrm{m} 111 \text { (just before } \\
\text { "Until you will") }\end{array}$ \\
\hline Lead vocals & $\begin{array}{l}\text { MF sings in three part harmony, } \\
\text { block chord texture; some } \\
\text { syncopation }\end{array}$ & $\begin{array}{l}\text { MF sings with unison doubling (no block } \\
\text { chord harmony); minimal syncopation }\end{array}$ \\
\hline Backup vocals & Block chord vocal harmony & $\begin{array}{l}\text { Unison "oohhs" in counterpoint to lead as } \\
\text { backup }\end{array}$ \\
\hline Bass guitar & $\begin{array}{l}\text { More of a triadic, leapy line with } \\
\text { just a bit of stepwise motion }\end{array}$ & Mostly stepwise motion \\
\hline Rhythm guitar & Quite prominent & More muted in the mix \\
\hline Lead guitar & $\begin{array}{l}\text { Accented plunky riffs punctuating } \\
\text { the vocals }\end{array}$ & $\begin{array}{l}\text { Steady figuration/ostinato, even, } \\
\text { unaccented, played throughout }\end{array}$ \\
\hline
\end{tabular}




\section{Marital-musical highs and lows}

The sense of elation that emerges from "How High the Moon" echoes accounts of the real-life couple during the initial phase of their relationship. According to Paul, the two fell in love on first meeting in 1945. Ford's friends and relatives, in contrast, reported to Shaughnessy that Ford was reluctant at first to enter into a relationship with Paul, but that he persisted and won her affections. Whatever the length of time between first meeting and romantic involvement, there is agreement that the couple quickly became intensely attached. Among Shaughnessy's informants are former colleagues who knew the couple when they first got together:

They were head over heels in love.... It was touching to watch them. He stared at her, practically salivating, and she looked at him like she couldn't believe he was real. You could feel the heat across the room.

We [drove long distances] several times, them in the front seat, me in back. He and Mary were so much in love they didn't seem to mind the long drives. But they almost had to put me away. All the hand holding and kissing was sickening. I used to tell them I was going to put a towel over my head if they didn't knock it off. ${ }^{47}$

The fact that they enjoyed each other's company so intensely suggests something of the “companionate marriage" espoused by marriage advice writers since the 1920 s, and reendorsed, albeit with even more emphasis on sexuality, in the 1950s.

\footnotetext{
${ }^{47}$ As told to Shaughnessy, Les Paul, 176, 192. First quotation, former deejay Bob Maxwell; second quotation, former Capitol Records staff member Dick Linke.
} 
Meanwhile, Paul and Ford's behavior with respect to marriage as an institution suggests that they were not struck by the conformist consensus, at least not in their early years together. They met while Paul was still married to and living with his first wife, Virginia. When Paul's first marriage did finally end in 1948, Ford moved in with him immediately. The pair did not get married until December 29, 1949, another year and a half after they began living together. The unconventional nature of this relationship was perhaps acceptable in the musical circles they moved in, but would have been frowned on by the public at large. It is likely for this reason that the couple decided to make their relationship official through marriage before beginning public performances together.

The whirlwind, passionate start of their relationship gave way to a tumultuous middle. The couple truly broke out commercially in spring 1951 with "How High the Moon," and by the end of the year they had earned $\$ 500,000$, and purchased a home in Mahwah, New Jersey. Success affected Paul and Ford differently: Paul maintained enthusiasm toward every new performance or promotional opportunity, whereas Ford began to desire tapering off performance and beginning to raise a family.

Shaughnessy describes the subsequent years of the Paul-Ford marriage as characterized by peaks and valleys. At the best of times, the couple still enjoyed recording together and still found enjoyment in each other's company. At the worst times, Ford was no longer able to cope with Paul's high energy and the busy performance schedule he imposed on them and she began to drink, perhaps as a coping mechanism. She balked over the fact that Paul controlled all of the finances and was incredibly thrifty despite their financial comfort. 
In November 1954, Ford gave birth to a premature infant who only survived for four days. This devastated the couple, and especially Ford, but they did recover for a time. They had two children five years later (one born to Mary, the other adopted) a development that seems to have buoyed the marriage for a few years longer, but again it started to fail. Ford left Paul in 1963, without her children, without possessions, or money, moving across the country to take refuge with her extended family. Over the next year, the couple engaged in a divorce battle in which Ford accused Paul of cruelty and Paul accused Ford of adultery. ${ }^{48}$

Although the reasons for their breakup are likely manifold, the start of the downward marriage trajectory is possibly connected to what would ideally have been the entrance to blissful domesticity, that is, the purchase of a home. An article about the couple's 1955 album Les and Mary carries an implicit (and unintentional) suggestion that home-owning did not in fact suit the couple very well. In his Chicago Tribune piece, Fred Reynolds explains to his readers that before Paul and Ford had the luxury and resources to work out of a home studio, the couple lived a nomadic lifestyle and recorded in adverse conditions, usually in hotel rooms during months-long tours. ${ }^{49}$ Reynolds evokes the contrast between the nomadic then and the domestic now to explain why the album under review is of such high quality: "In the matter of length [the album] is by far their longest.... and it is tops from a standpoint of sound too. Perhaps that is because it was all done leisurely at home." ${ }^{50}$ And yet Reynolds' contrast between then and now is ironic because several of the tracks recorded in "non-leisurely" conditions became big hits, and

\footnotetext{
${ }^{48}$ Shaughnessy, Les Paul, 249-251.

${ }^{49}$ Fred Reynolds, "Platter Chatter," Chicago Tribune, May 14, 1955.

${ }^{50}$ Reynolds, "Platter Chatter."
} 
by the time of this review, the duo's career was past its peak. It is true that their musical decline was part of a much broader trend in the music industry: most of their pop contemporaries experienced similar declines owing to the rise of rock ' $n$ ' roll. Yet looking at Reynolds' article in hindsight, it appears that "settling" into "normal" domestic married life did not help the couple's career as musicians, and neither did it help their marriage.

\section{Musical loneliness}

The couple's second of two number one hits was "Vaya Con Dios." Just as we might hear some of the Paul/Ford recordings through the lens of a sexually charged marital relationship, we might hear this record as a simultaneous presentation of connection and fracture in a way that echoes the dynamics of the real Paul-Ford relationship.

Billboard was lukewarm in its assessment of the 1953 single, saying, "This one is a slow semi-religious item which is handled in quiet style by the pair... [It] grows on you after a few plays." ${ }^{51}$ In contrast to Billboard, the record buying public was unequivocal: "Vaya Con Dios" reached number one on the pop charts and stayed there for 11 weeks.

The moderate tempo waltz ballad shows neither the flashy performance, nor the exciting arrangement features of the duo's best uptempo numbers; and it shows less guitar-voice interaction than many of their ballads. The record's incredible popularity is perhaps due to its status as a sad, wistful song that is nevertheless "catchy." It is easy to

\footnotetext{
${ }^{51}$ Billboard, June 6, 1953, 28.
} 
sing along with, and may have afforded listeners a chance to experience or share its measured expressions of yearning and regret.

The lyrical content invokes the category of what Gustavo Perez Firmat calls a "latune": an English-language American pop song that draws on oft-stereotyped Latin musical idioms and themes. With its Spanish title and refrain, and its inclusion of the Spanish word "hacienda," this song situates the speaker and her addressee in an unspecified Latin locale. As Perez Firmat points out, the geographic allusions in latunes are seldom meant to be specific; instead they can be used to create a sensual romantic atmosphere, or to conjure a place that is "so near, yet so far." 52

The lyrics present a tension between sorrow and hope. The speaker acknowledges that her imminent separation marks "the time for weeping," and yet she shows resolve and hopefulness rather than forlorn despair. She imagines she will be beside her lover in spirit while they are separated in the flesh ("Wherever you may be I'll be beside you/ Although you're many million dreams away"); and she draws solace from the fact that she will retain memories of their connection.

Ford's vocal performance communicates the tension between sadness and hope in the lyrics with her manipulation of rhythm and timbre. The melody centers on descending gestures, often moving in stepwise motion, major or minor seconds. The descending second which in classical music is known as a "sob" or "sigh"" motif takes on similar affective value here, particularly for the minor second on the syllables "Di-os" (from [E

\footnotetext{
${ }^{52}$ Gustavo Pérez Firmat, “Latunes: An Introduction,” Latin American Research Review 43, no. 2 (2008): $187,191$.
} 
down to D\#], which allows for an emphasis on the E because it is on the downbeat and rhythmically accented, further imbuing the gesture with a sob quality.

On the one hand, Ford uses her rhythmic delay to communicate sadness. Each iteration of the phrase "Vaya Con Dios" is further behind the beat than the last, suggesting an accumulation of sadness and lassitude as the song proceeds. Ford sings the refrain "Vaya Con Dios my darling/Vaya con Dios my love" a total of four times. But before her first presentation of this refrain, Paul wordlessly introduces its melody. His guitar statement of the refrain teaches us how this line "correctly" fits into the triple meter, swung-eighths groove.

The first time Ford sings the refrain, it is rhythmically very similar to Paul's introductory iteration. However, in her second, third and fourth articulations of the refrain, Ford increasingly stretches out the syllables and delays their onset. The increasing delay occurring over the four refrain iterations is subtle, but by the fourth one, the contrast with the first is significant. The increments in delay are small enough so that the listener might not register them consciously. But these delays help to create the sense of sadness and "deflation" surrounding the whole song. We might hear this sequence of performances as a real-time unfolding of the narrator's loss of resolve to keep composed, giving way to sobbing at the end. (See table 4.11)

Yet, while Ford's phrasing communicates the speaker's sadness, her vocal timbre and dynamics project composure. "Vaya Con Dios" is one of Ford's lowest-range songs: she sings between E3 and E4 with a single eighth-note foray to F\#4 during the B section. Compared to another very low-range song discussed above, “Take Me In Your Arms," 
Ford here retains a rich vocal tone rather than adopting a breathy timbre, and yet the low pitch range here nevertheless keeps her out of brassy belt territory. Her timbre conveys some edge, yet her voice does not sound strained. In addition to the comfortable sound of her vocal tone, she exudes a vocal steadiness by avoiding stark changes in timbre or dynamics.

If Ford's emotional/vocal self-regulation keeps the song from becoming sluggish or maudlin, so do the tune's steady groove and moderate tempo. Further, the bright, light guitar licks that Paul provides as punctuation for Ford's vocal lines keep this song in the balance between composed and despairing. Paul delivers his gestures precisely within the rhythmic grid, never lagging until the ritardando in the song's last measures. His very high range and light touch balance the low register and relative heaviness of Ford's voice.

It may be the delicate contrast of brightness and sadness in the lyric and sound, in Ford's own performance and in the Paul-Ford musical interaction that appealed so deeply to listeners. And yet, there is also a way to hear the piece as if the two musical personae are not engaged in supportive exchange but instead, have become emotionally distant. After all, Ford is fully charged with conveying the sadness of the song, even though she does moderate its intensity. Paul's bright guitar gestures never falter with respect to the rhythmic groove, even as Ford's vocal persona grows more dejected. If we understand the two musical personae as conveying a dialogue, Paul's gestures might say to Ford, "I will support you, I will cheer you up.” But they might also convey something like, "I prefer to stay cheerful." 
It is striking that the couple's most popular song, and their last number one hit, enacts the narrative of a couple parting: "Vaya Con Dios" the recording involves a married couple partnered musically creating a moving song about a couple's dissolution. It is true that many performers, male and female, performed songs about parting and heartbreak during the postwar pop era. But "Vaya" is certainly the most popular on the topic, and the only one performed by a real-life couple. There may have been something cathartic for audiences to hear a couple sing a sad song about a couple parting. It was a time when Americans were on the one hand told about the happy rewards of marriage, but at the same time may have been struggling to cope with isolation, dissatisfaction and resignation.

TABLE 4.11: "Vaya Con Dios" form and lyrics

\begin{tabular}{|c|c|c|}
\hline Measures & Section & Lyrics \\
\hline 8 & & Guitar intro: \\
\hline 16 & A & $\begin{array}{l}\text { Now the hacienda's dark, the town is sleeping, } \\
\text { Now the time has come to part, the time for weeping } \\
\text { Vaya con Dios my darling } \\
\text { Vaya con Dios my love }\end{array}$ \\
\hline 16 & A & $\begin{array}{l}\text { Now the village mission bells... } \\
\text { Vaya con Dios my darling } \\
\text { Vaya con Dios my love }\end{array}$ \\
\hline 16 & B & $\begin{array}{l}\text { Wherever you may be l'll be beside you... } \\
\ldots \\
\ldots \\
\ldots\end{array}$ \\
\hline 16 & A & $\begin{array}{l}\text { Now the dawn is breaking through... } \\
\text { V... } \\
\text { Vaya con Dios my darling } \\
\text { Vaya con Dios my love }\end{array}$ \\
\hline 16 & A & $\begin{array}{l}\text { Guitar solo } \\
\text { Guitar solo } \\
\text { Vaya Con Dios My Darling } \\
\text { Vaya Con Dios My Love }\end{array}$ \\
\hline
\end{tabular}




\section{FIGURE 4.4: Mary Ford's successive articulations of refrain in "Vaya Con Dios"}
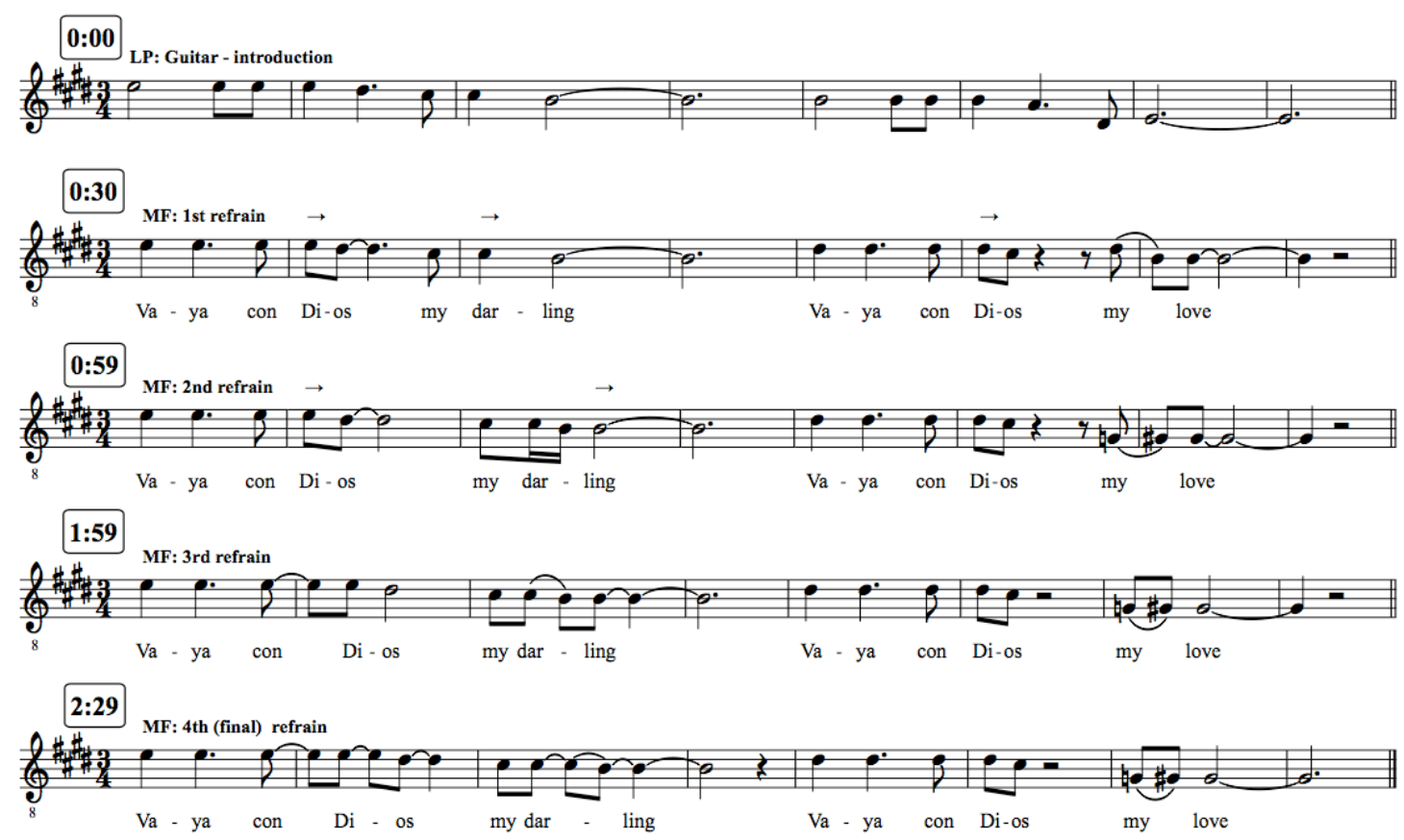

Mary Ford differs from other postwar pop singers most obviously in that she was not just a solo singer: she was one half of a musical act alongside her performer/ inventor/creator husband. She was also a skilled rhythm guitarist, and her playing features on nearly all of the duo's hits. In this way, her dual role as singer and guitarist sets her apart from female postwar pop singers.

Although Ford apparently did not contribute substantive creative ideas to the elaborate arrangements she recorded with Les Paul, I have argued that she exerted a powerful creative influence over her collaborations nonetheless. She was an "interactive muse" for Paul: her flexible voice, reliable rhythm guitar playing and her keen ear all gave Paul a rich musical palette to work with in creating multi-tracked recordings, made 
up of only voice and guitar. Even if Ford did not generate the musical ideas or make decisions about the final mixes, she likely inspired Paul's musical imagination simply because she presented so many musical possibilities. He would never again collaborate creatively with a vocalist after Ford.

Ford's vocal style bridged her soft shell country singing background with mainstream pop vocal style. When required by the song, Ford used a masterfully restrained close-mike delivery, and on these songs, her voice sounds uncannily proximate, as if she were singing into the listener's ear. On these same songs, Ford's performances might be heard as a discreet presentation of "marital" sexual allure. I have further suggested that on ballads and uptempo numbers, we might hear the exchange and interaction between Ford and Paul as sonic images of a couple's sexual connection. These presentations of connection in marriage are much more compelling and successful than the attempts the couple made to represent idealized domestic living.

In some ways Mary Ford's obscurity today is no different than that of other postwar pop singers who had great success during their time but whose names and work are unfamiliar today. And yet, in some ways, Ford's obscurity is worse. The partner with whom she attained so much success experienced a renaissance in the last decades of his life - decades during which Ford was no longer alive to even vie for a chance at remembrance. This chapter has served in part to help us un-forget her. 


\section{Conclusion}

The field of popular music scholarship is ripe for studies of pop singers that place vocal performance and vocal technique at their center. Singing is central to the appeal of popular music. And yet, the singing voice tends to resist close reading and analysis, as there exists little vocabulary to describe it outside of pedagogical or scientific circles. Perhaps because of this lack of standardized terminology, discussions of singers often focus on persona, image and relation to social context. And while these discussions can be illuminating, they leave a gap when it comes to understanding how singers mobilize their vocal instruments to make the sounds that in turn contribute to their performance personae and images. It is for this reason that my study has combined a discussion of singers' musical craft with discussions of persona, image and social norms and expectations.

I chose to study female postwar pop singers because of the striking fact that there was a spike in the number of successful professional women musicians during the postwar era, even though this was also an time during which women were urged to retreat form the public world of paid work and to embrace their position within the domestic sphere. These historical facts served as inspiration and catalyst for two scholarly motivations: first, to acknowledge and to bring to light this time during which women produced a relatively high proportion of best-selling recordings; and second, to interrogate to what extent, if any, they posed a challenge to social expectations of the day.

Doris Day, Patti Page and Mary Ford do not fall under the purview of traditional categories for inquiry in musicological study: they were "performers" rather than 
"creators," and tended to conform to social expectations rather than troubling them. When it comes to understanding their musical contributions and importance, I have not tried to attribute "genius" or artistic rupture to them. Rather, I have focused on the notion of musical craft: these singers all brought considerable talent and skill to their performing and recording careers. They worked within the structures of the mainstream commercial music industry and produced between them thousands of records that would delight and move audiences of the postwar generation. Their vocal craft centered on relaxed pop singing: a style that has since fallen out of favor in the popular sphere, and for this reason can be difficult to appreciate today. But when Day, Page and Ford made records, they each presented unique articulations of the desirable pop singing aesthetic of the era: one that was characterized by a smooth, even vocal tone, and the conveyance of ease and warmth.

Although Doris Day had the least "polish" of the singers studied here, she nevertheless developed a "workaround" technique that admitted her to the top singing ranks. Not only did her workaround technique render her lack of polish unimportant, but also it allowed her to access a range of expressive devices that helped her to communicate vibrant and varied personae, so that her singing was in some ways another outlet for her acting.

More than any other postwar pop singer, Page's technique incorporated aspects of classical style into pop singing, including her rich tone, powerful breath control, and wide, steady vibrato. To listeners who were not used to hearing these qualities, Page's singing would have constituted a dazzling display of vocal power, one that was 
augmented by her many overdubbed performances that presented her in an uncannily harmonious blend with her own voice.

Ford's range of talent and skill is the most unsung of these singers: by the time she partnered musically with Les Paul, she was a seasoned country radio performer and respected rhythm guitar player. Her flexible voice, with its many timbral capabilities, as well as her first-rate guitar playing and quick ability to learn and carry out complex arrangements were all contributors to the overall sound of the highly popular Paul/Ford records. What's more, as ballad singer, Ford honed a particularly low-pitched and breathy timbre in conjunction with Paul's practice of close miking.

To a certain extent, all of these singers performed conformity with respect to postwar norms and expectations. Day routinely played wholesome characters in her Warner Brothers films, characters whose optimism and energy made her attractive and winning to audiences and critics, and who never transgressed norms of sexual propriety. In performance and in images, Page presented a placid poise and a flourishing femininity. In these ways, she reflected the advice from popular and professional discourses that women would be happiest in cultivating a look and demeanor that was disposed to support and rejuvenate husbands and children. For their part, Ford and Paul would aim to present themselves as a happy couple who, in marriage, found the same happiness in domestic living that was encouraged and idealized in American postwar popular media. And yet the relationships these artists had with postwar norms is more complex than it first appears. The sometimes-circuitous discourse around Day's appeal suggests that many music and film audiences found her highly sexually desirable. Day managed to 
project sexual appeal through her energy, her physicality, and her singing voice, even as the discourse surrounding her reassured audiences that she was utterly non-threatening to the postwar moral codes and norms of marital stability.

There is a disjunction between the poised and placid visual images of Page, and the reactions her singing evoked in audiences. Listeners heard Page as powerful, and unparalleled by any other pop singer. Page's ultra-feminine look and poise may have been a necessary balance to the potentially disruptive power of her voice.

If Paul and Ford's media presentation of domestic contentment fell rather flat, the bitter breakup of the real-life couple's marriage in the early 1960s certainly undercuts notions that they were living out the kind of domestic "dream coupledom" idealized within postwar American culture. I have suggested that we might hear in their records, not only sonic images of marital/sexual connection but also of marital fracture.

In selecting subjects for this study, I chose singers who were very popular during their time rather than gravitating to singers with whom I felt a particular connection or musical affinity. Yet, in becoming deeply familiar with the work of Day, Page and Ford, I have developed affection for many (if not all) of their recordings, and an unequivocal respect for these singers' achievements. Doris Day, Patti Page, and Mary Ford may not have created aesthetic or social ruptures in ways that have historically been required for entry into the pop music canon. But they did something that, today as much as then, is more extraordinary than ordinary: they followed ambition and calling to perform for a living, and achieved successful careers doing what they loved. 


\section{Appendix}

\section{Reception descriptors applied to Day, Page and Ford}

To arrive at the ranked descriptors shown in table 1.5, I surveyed and grouped the adjectives and phrases used in singing-related press coverage of the Day, Page and Ford between 1945 and 1958. The descriptors are compiled from Billboard, The New York Times, The Chicago Tribune, and The Los Angeles Times. For the analysis, I first listed all of the descriptors applied to the singers' performances: this is shown in table A.1. I proceeded to group related terms and phrases, and then counted the frequency of given themes. (See table A.2) I then took these results and created a ranking of the most important themes in each singer's reception. (See table A.3)

TABLE A.1 Descriptors used in reviews

\begin{tabular}{|c|c|c|}
\hline Doris Day & Mary Ford & Patti Page \\
\hline $\begin{array}{l}\text { Sultry, songselling } \\
\text { Sultry } \\
\text { Expressive } \\
\text { Sexy, intimate, throaty } \\
\text { Personality } \\
\text { Moving } \\
\text { Sock } \\
\text { Warm } \\
\text { Warmly } \\
\text { Caresses sounds, huskiest, sexiest } \\
\text { Sensitive, feelingful }\end{array}$ & $\begin{array}{l}\text { Caresses, warm piping } \\
\text { Tender feeling } \\
\text { Warm sincerity } \\
\text { Warm } \\
\text { Much tenderness } \\
\text { With feeling } \\
\text { Very sincere } \\
\text { Torch side is compelling } \\
\text { Warm, soft } \\
\text { Summery fresh } \\
\text { Mighty warm } \\
\text { Warm and loving } \\
\text { Warm and sincere } \\
\text { Extra mellow, honeyed pipes }\end{array}$ & $\begin{array}{l}\text { Piping full and jazzappealwise } \\
\text { Inspired vocal } \\
\text { Warmth and persuasion } \\
\text { Feelingful duet } \\
\text { Strong virtuosic } \\
\text { Sincere } \\
\text { Superb, intimate } \\
\text { Distinctive sound } \\
\text { Forthright job } \\
\text { Sock job } \\
\text { Selling every line } \\
\text { Warm } \\
\text { Super projection } \\
\text { Emotion } \\
\text { Usual warm style } \\
\text { Poignant } \\
\text { Own powerful style } \\
\text { Sock performance } \\
\text { Inimitable style } \\
\text { Sparkling vocal } \\
\text { Ever-strong LaPage } \\
\text { Typically moving reading } \\
\text { Powerful } \\
\text { As only she can } \\
\text { Warm voice } \\
\text { Can sing any type of tune } \\
\text { Wonderful vocal } \\
\text { Typically touching } \\
\text { Warm, sincere, tasteful } \\
\text { Super syrupy }\end{array}$ \\
\hline
\end{tabular}


TABLE A.2 Descriptors grouped and counted

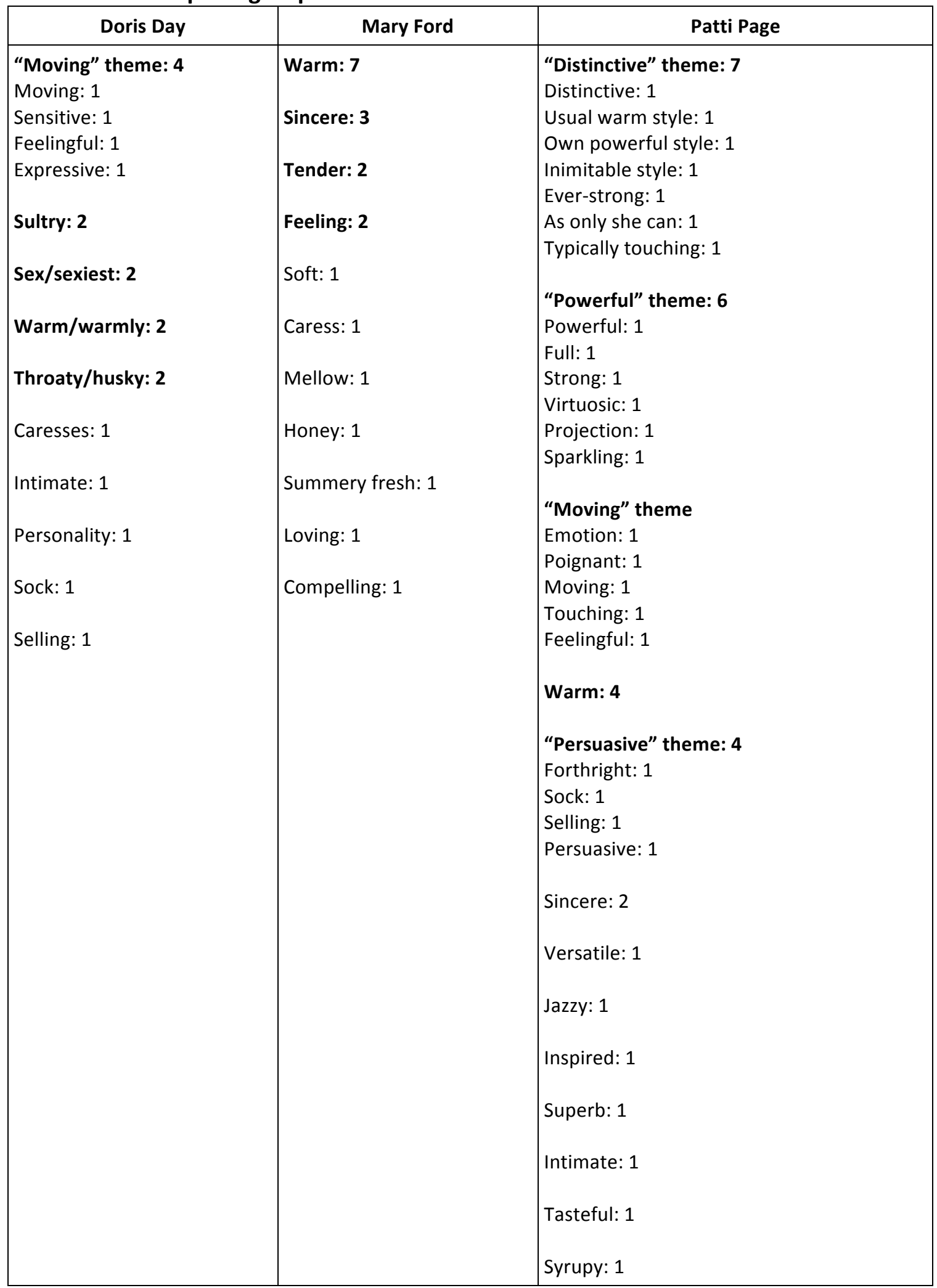


TABLE A.3 Descriptors grouped and ranked

\begin{tabular}{|l|l|l|}
\hline Doris Day & Mary Ford & Patti Page \\
\hline 1. Moving (4) & 1. Warm (7) & 1. Distinctive (7) \\
5. Sultry (2) & 2. Sincere (3) & 2. Powerful (6) \\
5. Sexy (2) & 3. Tender (2) & 3. Moving (5) \\
5. Warm (2) & 4. Feeling (2) & 5. Warm (4) \\
5. Throaty/husky (2) & & 5. Persuasive (4) \\
\hline
\end{tabular}




\section{Bibliography}

\section{Sound Recordings}

I obtained sound recordings for this dissertation through a combination of compact disc compilations and digital downloads. When I started my dissertation research, it was relatively easy to borrow or purchase compilation CDs of postwar pop music. However with every passing year, more and more historical compilations and reissues on $\mathrm{CD}$ have gone out of print. At the same time, more historical popular music has become available for online purchase. This has had mixed results for my research. It has been a boon in that I have been able to purchase digital versions of individual postwar songs that were previously rare or unavailable on $\mathrm{CD}$. However, there are challenges with this new way of obtaining historical pop music. Purchased digital downloads only sometimes include digital liner notes, so information about release dates (let alone recording dates and performance personnel) is often unavailable with this method of acquisition. There is also a problem with quality and authenticity: often, online digital stores sell multiple versions of a historical pop song, many of which are distributed by entities that are neither traditional nor well-known record labels.

Whenever possible, I have obtained the songs discussed here from CDs with liner notes. When this was not possible, I obtained the songs through online digital purchase. I then used a combination of sources to glean record label and release date information. These include Billboard, printed discography information in published sources (for example, biographies), and online discographies compiled by collectors and hobbyists.

In the list that follows, I provide the titles, with artist, record and release date, for the songs discussed in this dissertation. If no other information appears, it follows that I obtained the song as a digital download, and that I procured the label and date information from sources mentioned above. If instead I acquired the song from a compilation $\mathrm{CD}$, I then include that information after the original release details.

Brown, Les (with Doris Day.) "Sentimental Journey." Columbia, 1945. Doris Day: Her Life in Music: 1940-1966: Classic Collaborations, Columbia 5162152303, 2004.

Day, Doris. "It's Magic." Columbia, 1948. Doris Day: Her Life in Music: 1940-1966: Movie Hits, Columbia 5162152301, 2004.

. "Secret Love." Columbia, 1953. Doris Day: Her Life in Music: 1940-1966: Movie Hits, Columbia 5162152301, 2004.

- "Whatever Will Be, Will Be (Que Sera, Sera.)" Columbia, 1956. Doris Day: Her Life in Music: 1940-1966: Movie Hits, Columbia 5162152301, 2004. 
Durbin, Deanna. “Always.” Decca, 1944. The Very Best of Deanna Durbin, MasterSong, 2000 .

James, Joni. “Why Don’t You Believe Me.” MGM Records, 1952.

Page, Patti, "Confess." Mercury, 1948. The Patti Page Collection: The Mercury Years: Volume One, Mercury, 1991.

—. "I Went to Your Wedding." Mercury, 1952. The Patti Page Collection: The Mercury Years: Volume One, Mercury, 1991.

—. "Spring is Here," You Go To My Head, Mercury, 1956.

—_ "This is My Song." Mercury, 1953. The Patti Page Collection: The Mercury Years: Volume One, Mercury, 1991.

. "Why Don't You Believe Me." Mercury, 1952. The Patti Page Collection: The Mercury Years: Volume One, Mercury, 1991.

—. "With My Eyes Wide Open." Mercury, 1950. The Patti Page Collection: The Mercury Years: Volume One, Mercury, 1991.

—. "You Belong to Me." Mercury, 1952. The Patti Page Collection: The Mercury Years: Volume One, Mercury, 1991.

Paul, Les and Mary Ford. "How High the Moon." Capitol, 1951. The Best of the Capitol Masters: 90 ${ }^{\text {th }}$ Birthday Edition, Capitol, 2005.

- "Just One More Chance." Capitol, 1951. The Best of the Capitol Masters: $90^{\text {th }}$ Birthday Edition, Capitol, 2005.

—. "Take Me in Your Arms." Capitol, 1952.

—_. "Vaya Con Dios." Capitol, 1953. The Best of the Capitol Masters: 90 ${ }^{\text {th }}$ Birthday Edition, Capitol, 2005.

Stafford, Jo. "You Belong to Me.” Columbia, 1952.

Wakely, Jimmy. “One Has My Name (The Other Has My Heart).” Capitol, 1948.

—. "I Love You So Much it Hurts." Capitol, 1948.

Wakely, Jimmy and Margaret Whiting. “Slippin’ Around.” Capitol, 1949.

Wakely, Jimmy and the Sunshine Girls (featuring Mary Ford.) "I Wonder Where You Are Tonight." [Radio transcription, late 1940s.] 
Wells, Kitty. “It Wasn’t God Who Made Honky-Tonk Angels.” Decca, 1952.

\section{Films}

Bailey, Pearl, Sammy Davis, Mel Torme Maurice Chevalier, Patti Page, Jaybar Enterprises, and Entertainment Marketing Group. Sentimental Journey. Entertainment Marketing Group, 1992.

Paulson, John, James Arntz, Paulson Productions. Chasing Sound! The Les Paul Story. Musician, Inventor, Architect of Rock 'n' Roll. Icon Television Music, 2007.

\section{Books and Articles}

Auslander, Philip. "Musical Personae." TDR/The Drama Review 50, no. 1 (March 1, 2006): $100-119$.

Bateman, Laura Anne. "Soprano, Style and Voice Quality: Acoustic and Laryngographic Correlates." Master's Thesis, University of Victoria, 2003.

Bingham, Dennis. “'Before She Was a Virgin...': Doris Day and the Decline of Female Film Comedy in the 1950s and 1960s." Cinema Journal 45, no. 3 (2006): 3-31.

Björkner, Eva. "Musical Theater and Opera Singing - Why So Different? A Study of Subglottal Pressure, Voice Source, and Formant Frequency Characteristics." Journal of Voice 22 no. 5 (September 2008): 533-540.

Blyskal, Elena. "The Female Primo Passaggio: A Survey of Its Physiology, Psychology, and Pedagogy." Journal of Singing 69, no. 1 (2012): 11-19.

Bordman, Gerald, and Thomas S. Hischak. "Coe, Richard L[ivingstone]." The Oxford Companion to American Theatre. Oxford University Press, 2004.

Brackett, David. Interpreting Popular Music. Berkeley: University of California Press, 1995.

Cannam, Chris, Christian Landone, and Mark Sandler. "Sonic Visualiser: An Open Source Application for Viewing, Analysing, and Annotating Music Audio Files." In Proceedings of the ACM Multimedia 2010 International Conference. Firenze, Italy, 2010.

Chafe, William. The American Woman: Her Changing Social, Economic, and Political Roles, 1920-1970. New York: Oxford University Press, 1972. 
Clarke, Jane, and Diana Simmonds. Move Over Misconceptions: Doris Day Reappraised. BFI Dossier no. 4, London: British Film Institute, 1980.

Cook, Susan C. "'R-E-S-P-E-C-T (Find Out What It Means to Me)': Feminist Musicology and the Abject Popular." Women \& Music 5 (2001): 140-145.

Coontz, Stephanie. A Strange Stirring: The Feminine Mystique and American Women at the Dawn of the 1960s. New York: Basic Books, 2011.

- Marriage, a History: From Obedience to Intimacy, Or How Love Conquered Marriage. New York: Viking, 2005.

Cusick, Suzanne G. "Gender, Musicology and Feminism.” In Rethinking Music, edited by Mark Everist and Nicholas John Cook, 471-498. Oxford: Oxford University Press, 1999.

D’Emilio, John, and Estelle B. Freedman. Intimate Matters: A History of Sexuality in America. New York: Perennial Library, 1989.

Doyle, Peter. 'From 'My Blue Heaven' to 'Race with the Devil': Echo, Reverb and (dis)ordered Space in Early Popular Music Recording." Popular Music 23, no. 1 (2004): 31-49.

Drahota, Amy, Alan Costall, and Vasudevi Reddy. "The Vocal Communication of Different Kinds of Smile." Speech Communication 50 (2008): 278-287.

Dromey, Christopher, Lorie Reese, and J. Arden Hopkin. "Laryngeal-Level Amplitude Modulation in Vibrato.” Journal of Voice 23, no. 2 (2009): 156-163.

Escott, Colin. Roadkill on the Three-chord Highway: Art and Trash in American Popular Music. New York: Routledge, 2002.

Friedwald, Will. A Biographical Guide to the Great Jazz and Pop Singers. New York: Pantheon Books, 2010.

Gentry, Philip. "Now I Know Just How Much I Have Lost: Post-War Popular Music and the Sound of Whiteness." In "The Age of Anxiety: Music, Politics and McCarthyism, 19481954.” PhD Dissertation, University of California, Los Angeles, 2008.

Gerhard, Jane F. Desiring Revolution: Second-wave Feminism and the Rewriting of American Sexual Thought, 1920 to 1982. New York: Columbia University Press, 2001.

Giddins, Gary. Bing Crosby: A Pocketful of Dreams: The Early Years 1903-1940. Boston: Little Brown and Co, 2001. 
Greenberg, Jonathan Ross. "Singing Up Close: Voice, Language, and Race in American Popular Music, 1925-1935.” PhD Dissertation, University of California, Los Angeles, 2008.

Hamm, Charles. Yesterdays: Popular Song in America. New York: Norton, 1979.

Hartman, Lee. “'Que Sera Sera:’ The English Roots of a Pseudo-Spanish Proverb.” Proverbium 30 (2013): 51-104.

Haskell, Molly. From Reverence to Rape: The Treatment of Women in the Movies. 2nd ed. Chicago: University of Chicago Press, 1987. First published 1974.

Hotchner, A. Doris Day: Her Own Story. New York: William Morrow, 1975.

Kaufman, David. Doris Day: The Untold Story of the Girl Next Door. New York: Virgin Books, 2008.

Lacasse, Serge. “'Listen to My Voice': The Evocative Power of Vocal Staging in Recorded Rock Music and Other Forms of Vocal Expression." PhD dissertation, University of Liverpool, 2000.

Lanza, Joseph. Vanilla Pop: Sweet Sounds from Frankie Avalon to ABBA. Chicago Review Press, 2005.

Lebowitz, Amy and R.J. Baken. "Correlates of the Belt Voice: A Broader Examination." Journal of Voice 25, no. 2 (2011): 160-165.

Lovetri, Jeannette L. "Contemporary Commercial Music: More Than One Way to Use the Vocal Tract.” Journal of Singing 58, no. 3 (January 2002): 249-252.

Marling, Karal Ann. As Seen on TV: The Visual Culture of Everyday Life in the 1950s. Cambridge, Mass.: Harvard University Press, 1996.

May, Elaine Tyler. Homeward Bound: American Families in the Cold War Era. New York: Basic Books, 1999.

Miller, James. Flowers in the Dustbin: The Rise of Rock and Roll, 1947-1977. New York: Touchstone, 2000.

O'Dair, Barbara. Trouble Girls: The Rolling Stone Book of Women in Rock. New York: Random House, 1997.

Page, Patti. Once Upon a Dream: A Personal Chat with All Teenagers. New York: Popular Library, 1960.

_. This Is My Song: A Memoir. Bath, New Hampshire: Kathdan Books, 2009. 
Paul, Les, and Michael Cochran. Les Paul: In His Own Words. York, Pennsylvania: Gemstone Publishing, 2008.

Pérez Firmat, Gustavo. "Latunes: An Introduction." Latin American Research Review 43, no. 2 (2008): 180-203.

Peterson, Richard A. Creating Country Music: Fabricating Authenticity. Chicago: University of Chicago Press, 1997.

Replogle-Wong, Holley Dawn. "Crossover and Spectacle in American Operetta and the Megamusical.” Ph.D., University of California, Los Angeles, 2009.

Santopietro, Tom. Considering Doris Day. New York: Thomas Dunne Books, 2007.

Savoy, Eric. “"That Ain't All She Ain't': Doris Day and Queer Performativity.” In Out Takes: Essays on Queer Theory and Film, 51-182. Durham: Duke University Press, 1999.

Schoemer, Karen. Great Pretenders: My Strange Love Affair with '50s Pop Music. New York: Free Press, 2006.

Schutte, HK, and DG Miller. "Belting and Pop, Nonclassical Approaches to the Female Middle Voice: Some Preliminary Considerations.” Journal of Voice 7, no. 2 (June 1993): $142-250$.

Shaughnessy, Mary Alice. Les Paul: An American Original. New York: W. Morrow, 1993.

Stacey, Jackie. Star Gazing: Hollywood and Female Spectatorship. New York: Routledge, 1994.

Starr, Larry, and Christopher Alan Waterman. American Popular Music: From Minstrelsy to MP3. New York: Oxford University Press, 2007.

Titze, Ingo R, Albert S. Worley, and Brad H. Story. "Source-Vocal Tract Interaction in Female Operatic Singing and Theater Belting." Journal of Singing 67, no. 5 (May 2011): $561-572$.

Titze, Ingo R. “The Human Instrument.” Scientific American, January 2008.

Updike, John. "Suzie Creamcheese Speaks.” The New Yorker, February 23, 1976.

Vander Wel, Stephanie. "'I Am a Honky-tonk Girl”: Country Music, Gender, and Migration.” $\mathrm{PhD}$ dissertation, University of California, Los Angeles, 2008.

Waksman, Steve. Instruments of Desire: The Electric Guitar and the Shaping of Musical Experience. Cambridge, Mass.: Harvard University Press, 1999. 
Wald, Elijah. Escaping the Delta: Robert Johnson and the Invention of the Blues. New York: Amistad, 2004.

. How the Beatles Destroyed Rock ' $n$ ' Roll: An Alternative History of American Popular Music. Oxford University Press, 2009.

Whitburn, Joel. Billboard Top 1000 Singles, 1955-2000. Milwaukee: H. Leonard Corp., 2001.

- Joel Whitburn Presents a Century of Pop Music: Year-by-year Top 40 Rankings of the Songs \& Artists That Shaped a Century. Menomonee Falls, Wisconsin: Record Research, 1999.

—. Joel Whitburn's Pop Hits, 1940-1954: Compiled from Billboard's Pop Singles Charts 1940-1954. Menomonee Falls, Wisconsin: Record Research, 2002.

Wilson, Carl. Let's Talk About Love: A Journey to the End of Taste. New York: Continuum, 2007.

Ybarra, David Nick. "Patti Page: Record of a Legend, Journey of a Woman.” Daeida Magazine, November 2010.

Zak, Albin. I Don't Sound Like Nobody: Remaking Music in 1950s America. Ann Arbor, Michigan: University of Michigan Press, 2010. 